\title{
FACULTAD DE
}

\section{CIENCIAS VETERINARIAS}

UNIVERSIDAD NACIONAL de LA PLATA

\author{
UNIVERSIDAD NACIONAL DE LA PLATA
}

Facultad de Ciencias Veterinarias

Trabajo de Tesis realizado como requisito para optar al título de DOCTOR EN CIENCIAS VETERINARIAS

ESTUDIO DE LOS FACTORES DE ADHERENCIA DE CEPAS DE Escherichia coli PRODUCTORAS DE TOXINA SHIGA AISLADAS DE BOVINOS

AUTOR: GALLI, Lucía

DIRECTOR: LEOTTA, Gerardo Aníbal

CO-DIRECTOR: RIVAS, Marta

ASESOR EXTERNO: TORRES, Alfredo G.

\section{LUGAR DE TRABAJO}

Servicio Fisiopatogenia, Departamento Bacteriología, Instituto Nacional de Enfermedades Infecciosas, ANLIS “Dr. Carlos G. Malbrán” 
A Pablo, mi gran amory sostén 


\section{AGRADECIMIENTOS}

Estoy emocionada y contenta por terminar la tesis que arrancó hace aproximadamente 5 años, aunque ya hace un poco más que trabajo en FP, y cuando recuerdo algo de los comienzos se me viene a la cabeza la voz de un picasesos que me decía "anotate al doctorado", gracias Gerar por todo tu apoyo y principalmente confiar en mi.

Tengo una lista interminable de gente a la que agradecerle. Para ser imparcial voy a hacer un muestreo al azar sin reposición de los nombres para que ninguno se ofenda y espero no olvidarme de nadie, sí, sí, nadie1, nadie 2 , nadie $3 . . .$.

En todo este tiempo recibí la confianza, el cariño y el apoyo incondicional de todos mis compañeros y amigos del Servicio Fisiopatogenia (FP, como me gusta decirle). Agradezco a Marta, Isa, Eli, Caro, Nati, Ari, Bety, Gise, Juli, Nati, Sofi, y al "bendito" Eduardo, sabelo que voy a extrañar las tardes sin radio América y nuestras charlas eternas. No puedo dejar de agradecerle a mis ex-compañeras Juli, Eli y Anita que formaron parte de los comienzos y cada una también dejó una marca personal en mi corazón. Cómo olvidar los días enteros picando colonias con Daniel y más aún armando las tablas de excel con las cepas!!!

Tampoco me olvido de Alfredo y todo el esfuerzo que hizo por ayudarme. De las interminables cadenas de mails discutiendo sobre los experimentos y de las rebanadas de seso por querer encontrar una explicación a todo. De Torre's Lab, que apesar de haber estado muy poco tiempo con ellos supieron adoptarme como una más, nada hubiera sido lo mismo sin Marita, Carla, Roberto, Doug, Shane, Tiff y Katie. 
Y si hablando de laboratorios se trata, no puedo dejar de mencionar a la gente del INTA, a Mariano, Elsa, Betina, Dani, Lori y Ana, que supieron entregarme un lugarcito y toda la ayuda del mundo.

Agradezco a todos los servicios del Malbrán que siempre me ayudaron cuando fui con alguna duda y sobre todo a Diego por su ayuda desinteresada.

A Laurita por los dibujos y la edición. Y principalmente quiero agradecerle a mi FAMILIA y AMIGOS por su apoyo incondicional. Estoy y estaré eternamente agradecida con todos!!!

Y si me olvidé de vos y estas leyendo esta tesis por alguna de esas casualidades de la vida, MUCHAS GRACIAS TAMBIEN!!! 


\section{CITAS BIBLIOGRÁFICAS CORRESPONDIENTES A LAS PUBLICACIONES PARCIALES DEL TRABAJO DE TESIS}

- Galli L, Miliwebsky E, Irino K, Leotta GA, Rivas M. Virulence profile comparison between LEE-negative Shiga toxin-producing Escherichia coli strains isolated from cattle and humans. Vet Microbiol. 2010;143:307-313.

- Galli L, Torres AG, Rivas M. Identification of the long polar fimbriae gene variants in the locus of enterocyte effacement-negative Shiga toxin-producing Escherichia coli strains isolated from humans and cattle in Argentina. FEMS Microbiol Lett. 2010;308:123-129. 


\section{INDICE}

LISTA DE ABREVIATURAS --

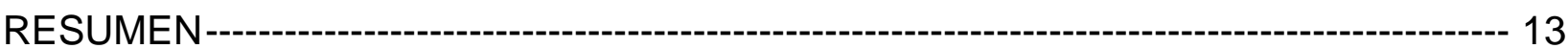

1. INTRODUCCION --- 14

1.1.- Escherichia coli productor de toxina Shiga----_-

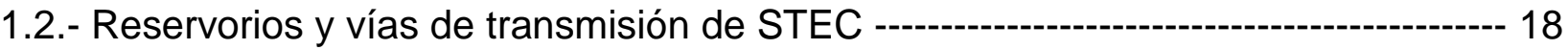

1.3.- Manifestaciones clínicas de la infección por STEC---_-

1.4.- Estrategias de la infección por STEC --- 25

A) Patogénesis------- 25

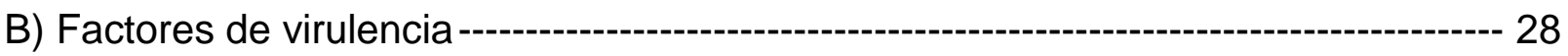

B.1.- Toxina Shiga --- 29

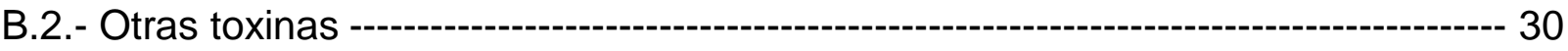

B.3.- Factores de adherencia intestinal ---on 31

Codificados dentro la región LEE --.-- 31

B.3.1.- Intimina como factor clave de colonización --- 31

Codificados fuera de la región LEE --.-- 33

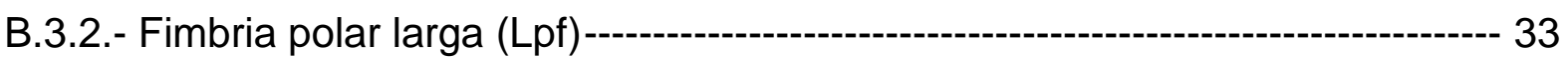

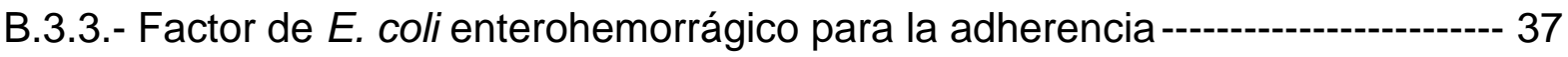

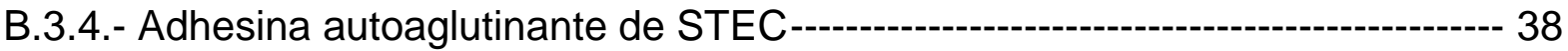

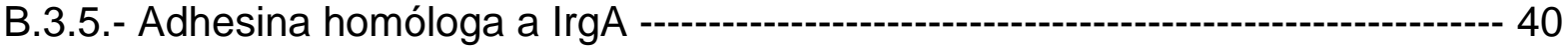

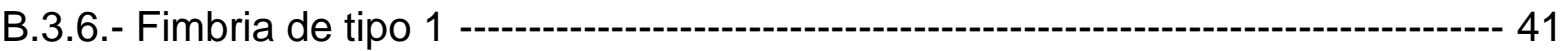

B.3.7.- Curli-------o- 42

B.3.8.- Flagelos----_- 44

1.5.- Situación actual del SUH en Argentina -----_- 45

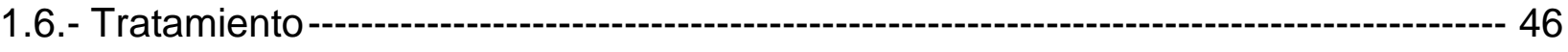

1.7.- Control de STEC en el ganado bovino ---_-

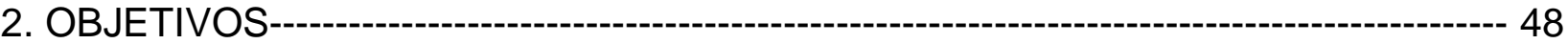

3. MATERIALES Y METODOS --- 50

3.1.- Cepas bacterianas y plásmidos---

3.2.- Medios y condiciones de crecimiento bacteriano -- 51

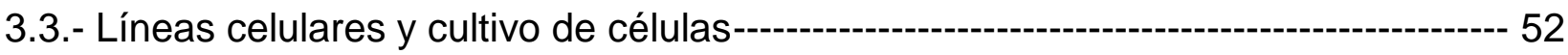


3.4.- Caracterización genotípica 53

3.4.1.- Aislamiento de ADN total 57

3.4.2.- Electroforesis y adquisición de imágenes 57

3.5.- Ensayo de aglutinación de las fimbrias de tipo 1 --_- 57

3.5.1.- Determinación del estado de orientación de $\operatorname{fimA-}$

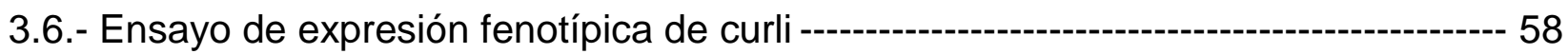

3.7.- Secuenciación nucleotídica ---_-- 59

3.8.- Adherencia bacteriana in vitro---_- 59

3.8.1.- Ensayo cualitativo --- 59

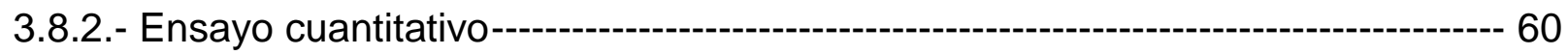

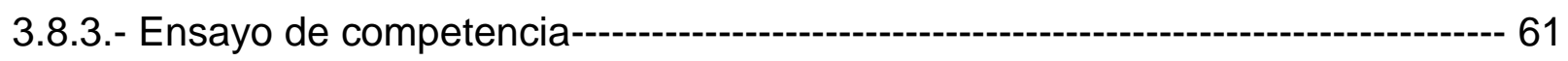

3.9.- Invasión bacteriana in vitro--- 61

3.10.- Análisis estadístico de los resultados de adherencia e invasión ------------- 62

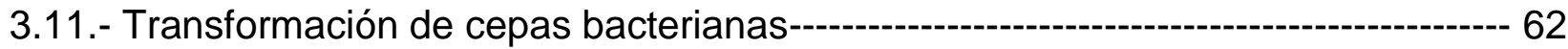

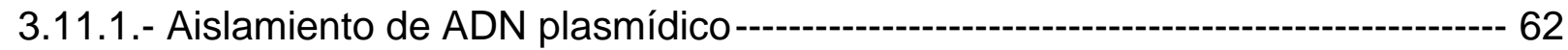

3.11.2.- Preparación de bacterias electrocompetentes --_-_-_-_-_- 63

3.11.3.- Electroporación ------on 64

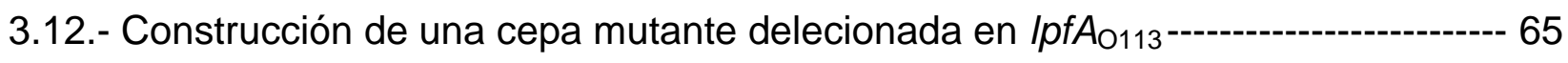

3.12.1.- Purificación de fragmentos de ADN-- 65

3.12.2.- Construcción de la mutante IpfA -- 65

3.13.- Extracción de proteínas por calor-- 66

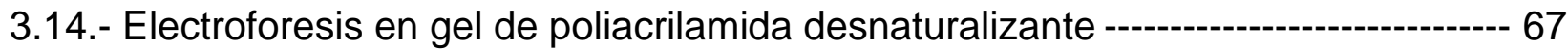

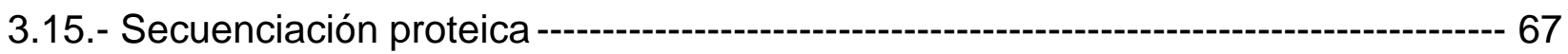

4. RESULTADOS --- 68

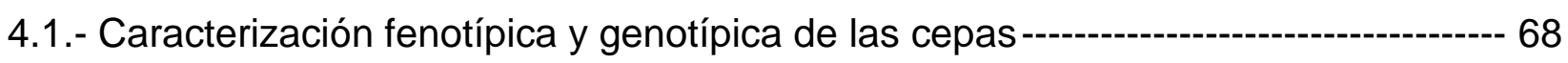

4.2.- Marcadores de virulencia --- 72

4.2.1.- Variantes de $I p f A$------ 74

4.3.- Comparación del perfil de virulencia de las cepas estudiadas ---

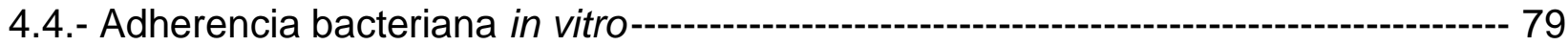

4.4.1.- Ensayos cualitativos de adherencia in vitro---_-_-_-_-_-_- 79

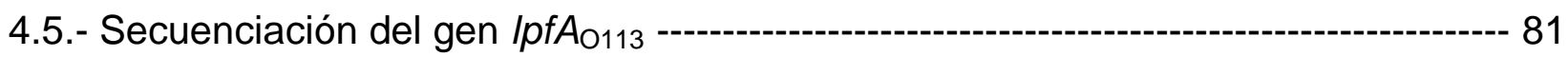

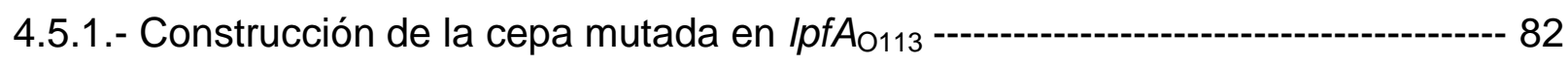


4.6.- Contribución de Lpf a la adherencia de la cepa STEC O136:H12--.-- 83

5. DISCUSION--- 90

5.1.- Prevalencia de factores de virulencia de cepas STEC LEE-negativas------------ 90

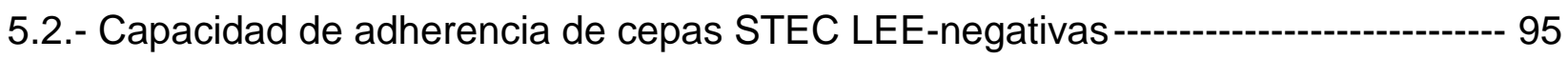

6. CONCLUSIONES ------on

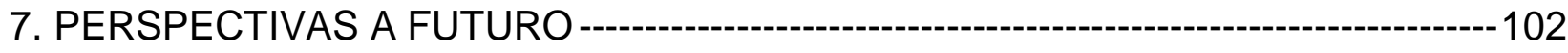

8. BIBLIOGRAFIA -----on 


\section{LISTA DE ABREVIATURAS}

A/E Adherencia y destrucción de microvellosidades (ㅁattaching and êffacing).

ADN Ácido desoxirribonucleico.

Amp Ampicilina.

APEC Escherichia coli patógena de aves (avian pathogenic 트. oll).

ARN Ácido ribonucleico.

ATS Agar tripticasa de soja.

CDT Toxina distensora citoletal (cytolethal distending toxin).

$\mathrm{CH} \quad$ Colitis hemorrágica.

$\mathrm{CHO} \quad$ Células de ovario de hamster Chino (ㅁhinese hamster $\underline{\text { ovary}}$ ).

$\mathrm{Cm} \quad$ Cloranfenicol.

CTS Caldo tripticasa de soja.

CDC Centro para la Prevención y el Control de Enfermedades ( $\underline{C} e n t e r s$ for

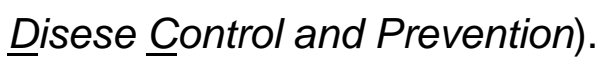

D Diarrea.

DAEC Escherichia coli de adherencia difusa (diffuse-âdherent $\underline{E}$. çoli).

DEC Escherichia coli diarreigénicos (diarrheagenic E. coll).

DMEM Medio de Eagle modificado por Dulbecco (ㅁulbecco's modified Eagle's médium).

dNTP Desoxinucleótido trifosfato.

DO Densidad óptica.

DS Diarrea sanguinolenta.

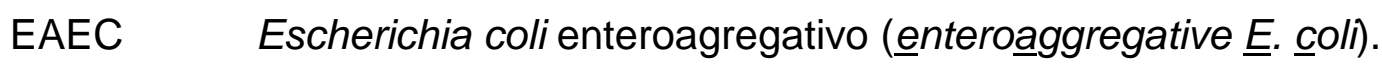

EAST Toxina estable al calor de E. coli enteroagregativo (enteroaggregative E. coli heat-stable toxin).

EDTA Ácido etilen-diamino-tetra-acético (ethylene diamine tetra accetic acid).

EE.UU. Estados Unidos de Norteamérica.

Efa Factor de E. coli enterohemorrágico para la adherencia-1 (enterohemorrhagic E. coli factor for a adherence).

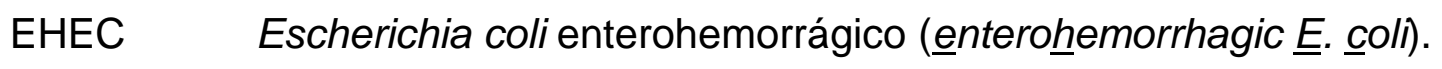

EIEC Escherichia coli enteroinvasivo (enteroinvasive E. coll). 


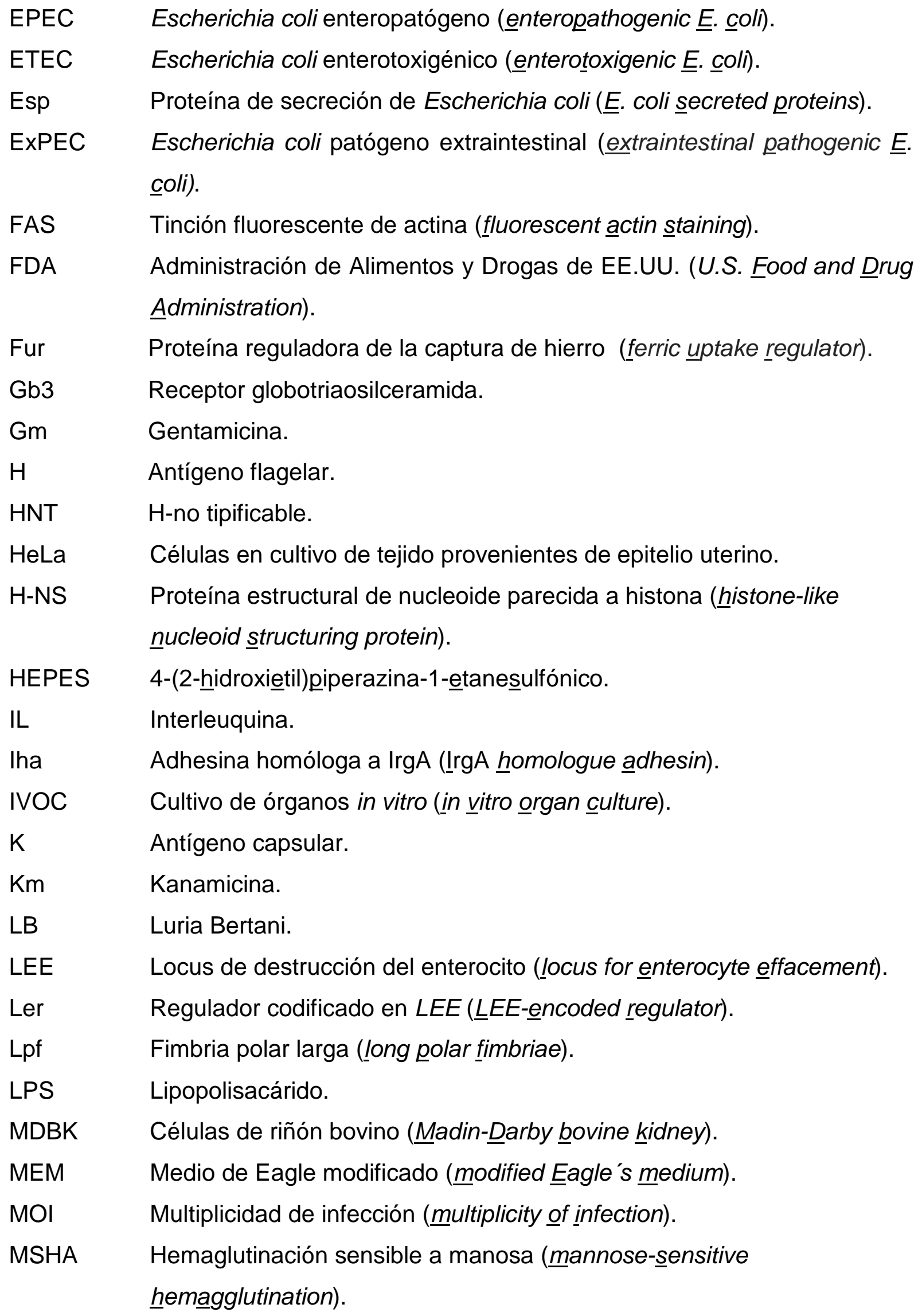




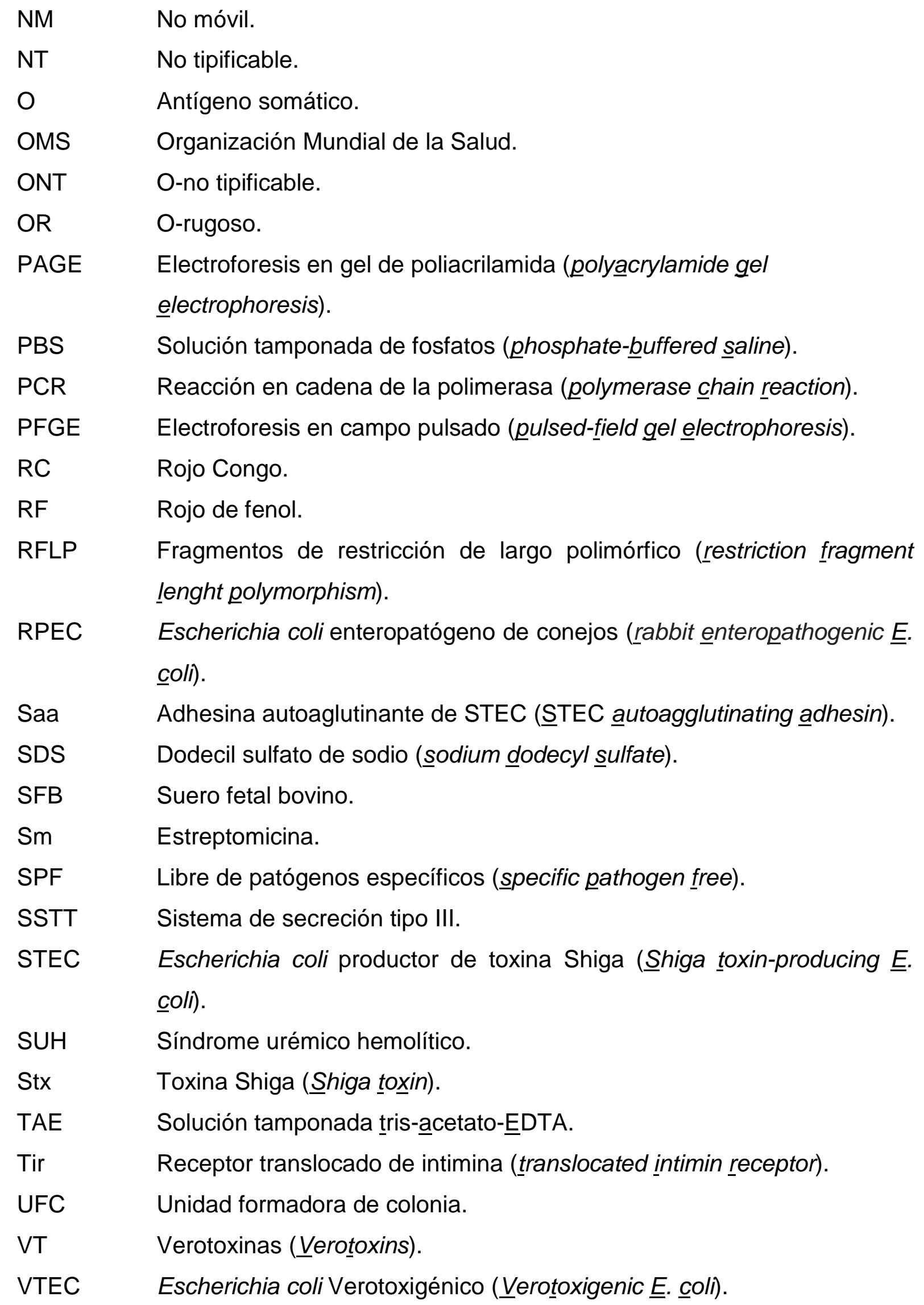


$\begin{array}{ll}\text { v/v } & \text { Volumen en volumen. } \\ \text { y col. } & \text { y colaboradores. }\end{array}$

Unidades de medida

C Grados centígrados.

ca. Circa.

h Horas

$\mathrm{kDa} \quad$ Kilodaltones.

$\mathrm{kpb} \quad$ Kilopares de bases.

pb Pares de bases.

mg Miligramos.

$\mu \mathrm{g} \quad$ Microgramos.

ng Nanogramos.

min Minutos.

$\mathrm{ml} \quad$ Mililitros.

$\mu \mathrm{l} \quad$ Microlitros.

$\mathrm{mM}$ Milimolar.

$\mu \mathrm{M} \quad$ Micromolar.

rpm Revoluciones por minuto.

seg Segundos.

v Voltios. 


\section{RESUMEN}

\section{"Estudio de los factores de adherencia de cepas de Escherichia coli productoras de toxina Shiga aisladas de bovinos"}

Escherichia coli productor de toxina Shiga (STEC) es un patógeno de transmición alimentaria con un demostrado carácter zoonótico que representa un grave problema para la Salud Pública, ya que ocasiona brotes y es responsable de la ocurrencia del potencial fatal síndrome urémico hemolítico (SUH). En Argentina el SUH es endémico y constituye la primera causa de insuficiencia renal aguda en niños menores de 5 años. El principal reservorio de STEC es el ganado bovino sano a pesar que un número limitados de serotipos fueron asociados con diarrea en terneros. El serotipo de STEC mayormente asociado a enfermedad humana es 0157:H7, pero existen más de 100 serotipos no-0157 capaces de causar enfermedad en el hombre. La carencia de secuencias génicas completas de cepas STEC no-O157 limitó el descubrimiento científico sobre las diferencias de las bases genéticas respecto a la virulencia. Con el objetivo de dilucidar posibles mecanismos de patogenia de este grupo bacteriano heterogéneo, se determinó mediante la técnica de reacción en cadena de la polimerasa (PCR) la prevalencia de seis genes que codifican posibles adhesinas y tres toxinas en una colección de 200 cepas STEC no-O157 LEE-negativas aisladas de reservorio animal y de infecciones humanas, siendo $I p f A_{0113}$ el gen identificado como más prevalente (99,5\%). Además se demostró que las cepas STEC LEE-negativas bovinas poseen genes que codifican para adhesinas putativas y toxinas presentes en las cepas STEC LEEnegativas aisladas de casos de infección humana. Sin embargo, en el subgrupo de cepas estudiadas y bajo las condiciones ensayadas en el presente trabajo, Lpf2 no resultó ser la principal adhesina que participa en los mecanismos de pegado o interacción a células epiteliales in vitro.

\section{Palabras claves:}

STEC LEE-negativas, factores de virulencia, adhesinas, patogénesis, adherencia. 


\section{SUMMARY}

\section{'Study of the adherence factors of Shiga toxin-producing Escherichia coli isolated from cattle'}

Shiga toxin-producing Escherichia coli (STEC) are zoonotic foodborne pathogens that are a serious public health concern because they cause outbreaks and the potentially fatal hemolytic uremic syndrome (HUS). In Argentina the HUS is endemic, and is the leading cause of acute renal failure among children. The main reservoir of STEC is healthy cattle while a limited number of serotypes have been associated with diarrhea in calves. The most common STEC serotype associated with human disease is $\mathrm{O} 157: \mathrm{H} 7$, but there is a growing recognition of over 100 non-O157 serotypes that also may result in human illness. The scarceness of whole genome sequence data for non-0157 STEC has limited the scientific discovery into the genetic basis of these differences in virulence. With the aim to elucidate possible mechanisms of pathogenesis of this heterogeneous bacterial group, the prevalence of six putative adhesin-encoding genes and three toxins were investigated in a 200strain collection of LEE-negative non-0157 STEC strains isolated from cattle and human infections, being $I p f A_{0113}$ the most prevalent virulence gene identified $(99,5 \%)$. It was also showed that bovine LEE-negative STEC strains possess genes encoding for putative adhesins and toxins present in human LEE-negative STEC strains. However, in the subgroup of strains studied and under the conditions tested, Lpf2 not proved to be the main adhesin involved in the mechanisms of adherence or interaction with epithelial cells in vitro.

\section{Key words:}

LEE-negative STEC, virulence factors, adhesins, pathogenesis, adherence. 


\section{INTRODUCCION}

Escherichia coli (E. coli) es probablemente el organismo más estudiado en Microbiología. Desde su primera descripción (Escherich, 1885), se convirtió en el organismo modelo de muchas investigaciones microbiológicas, tanto que a menudo se olvida que su principal nicho ecológico es el tracto alimenticio del hombre y de la mayoría de los animales de sangre caliente.

La mayoría de las cepas de E. coli son comensales, pero algunas de ellas pueden causar enfermedad tanto en el hombre como en animales. Hasta el presente, se reconocen seis categorías asociadas a infecciones gastrointestinales (DEC, por sus siglas en inglés diarrheagenic $E$. coli), aparte de aquellas causantes de infecciones urinarias, septicemia y meningitis (ExPEC, E. coli extraintestinales).

Los patotipos asociados a infeciones gastrointestinales se clasifican según sus manifestaciones clínicas, patogenicidad, y características epidemiológicas en:

- E. coli enteropatógeno (EPEC, por su siglas en inglés enteropathogenic E. coli).

- E. coli enterotoxigénico (ETEC, por su siglas en inglés enterotoxigenic E. coli).

- E. coli productor de toxina Shiga (STEC, por su siglas en inglés Shiga toxinproducing E. coli).

- E. coli enteroinvasivo (EIEC, por su siglas en inglés enteroinvasive E. coli).

- E. coli enteroagregativo (EAEC, por su siglas en inglés enteroaggregative E. coll).

- E. coli de adherencia difusa (DAEC, por su siglas en inglés diffuse-adherent $E$. coli).

En el intestino humano, ETEC, EPEC y EAEC colonizan el intestino delgado, mientras que EIEC y STEC colonizan el intestino grueso. Debido al gran número de 
cepas DAEC, la localización exacta para la colonización intestinal de esta categoría no fue definida (Williams y col., 2011).

Los aislamientos se diferencian serológicamente por los antígenos somáticos $(\mathrm{O})$, flagelar $(\mathrm{H})$ y capsular $(\mathrm{K})$. Hasta el presente se identificaron 181 antígenos $\mathrm{O}$ y 53 antígenos H (Scheutz, comunicación personal). Los antígenos O definen un serogupo, y una combinación específica de antígenos $\mathrm{O}$ y $\mathrm{H}$ definen el serotipo de un aislamiento.

En este trabajo nos focalizaremos específicamente en el grupo bacteriano $E$. coli productor de toxina Shiga.

\section{1.- Escherichia coli productor de toxina Shiga}

Las cepas STEC se caracterizan por su habilidad de producir al menos un tipo de toxina que pertenece a una clase de potentes citotoxinas que tienen la capacidad de inhibir la síntesis proteica en células eucariotas. Estas toxinas fueron denominadas en un primer momento como Verotoxinas (VT, por sus siglas en inglés Verotoxins), por su efecto citotóxico en células Vero (Knowalchuk y col., 1977). Pocos años después, se observó que también producían un efecto citotóxico en células HeLa, el cual podía ser neutralizado por anticuerpos anti-toxina Shiga de Shigella dysenteriae tipo 1 (O’Brien y col., 1982), y se las denominó toxinas Shiga (Stx, por sus siglas en inglés Shiga toxins). Por lo tanto, la denominación de VTEC (por sus siglas en inglés Verotoxigenic $E$. coli) y STEC son equivalentes y definen a todas las cepas $E$. coli que producen una o más toxinas de la familia Stx (VT).

STEC fue descripto por primera vez por Knowalchuk en 1977 (Knowalchuk y col., 1977), quien informó que cepas E. coli de los serogrupos O18, O26, O111 y 
O128 aisladas de niños y cerdos con diarrea producían una toxina extracelular con propiedades citotóxicas sobre células Vero. Pero la importancia de STEC como patógeno humano cobró notoriedad recién en 1982, cuando se produjeron dos brotes de diarrea sanguinolenta severa, denominada colítis hemorrágica $(\mathrm{CH})$, en los estados de Michigan y Oregon (EE.UU.) causados por el consumo de hamburguesas, identificándose por primera vez el serotipo 0157:H7 como patógeno humano (Riley y col., 1983).

El término Escherichia coli enterohemorrágico (EHEC, por sus siglas en inglés enterohemorragic $E$. coli) es utilizado frecuentemente para describir un sub-grupo de cepas STEC responsables de causar enfermedad severa en el hombre como $\mathrm{CH}$ y síndrome urémico hemolítico (SUH), del cual E. coli O157:H7 es la cepa prototipo. Además de expresar Stx, este grupo bacteriano posee factores de virulencia adicionales, como la isla de patogenicidad LEE (por sus siglas en inglés Locus for Enterocyte Effacement), que codifica para un sistema de secresión tipo III y proteínas efectoras homólogas a aquellas producidas por EPEC (Kaper y col., 2004). Sin embargo, existen cepas STEC LEE-negativas capaces de causar enfermedad severa, por lo tanto resulta adecuada la utilización de un término más general, como STEC, para referirse a todas las cepas de E. coli capaces de producir Stx.

Dentro del grupo de las STEC, E. coli $\mathrm{O} 157: \mathrm{H} 7$ es el serotipo aislado más frecuentemente y al que se le atribuye la ocurrencia de la mayoría de los grandes brotes como los registrados en la costa oeste de Estados Unidos en 1993 (Barret y col., 1994) y en Japón en 1996 (Watanabe y col., 1996). Pero existen otros serotipos STEC no-O157 que también pueden causar enfermedad y la ocurrencia de grandes brotes, como el descripto a comienzos de mayo de 2011 en Alemania y que se 
extendió a 13 países miembro de la Unión Europea, Canadá y EE.UU., asociado a E. coli $0104: \mathrm{H} 4$, causando aproximadamente 3.500 casos de infección, incluyendo 810 casos de SUH y 39 muertes. La particularidad de este brote fue el predominio de mujeres adultas implicadas, complicaciones neurológicas severas y las características de la cepa involucrada, ya que la misma no fue una "típica" STEC virulenta, sino un patotipo híbrido no habitual que portaba la codificación mediada por fagos para Stx2 pero con una base genética de EAEC, al cual se lo denominó $E$. coli enteroagregativo productor de toxina Shiga (Bielaszewska y col., 2011).

Si bien la mayoría de los estudios están orientados a la detección de E. coli O157, en la actualidad han aumentado los esfuerzos para detectar los diferentes serotipos de STEC. A diferencia de lo que ocurre con O157:H7, que no fermenta sorbitol y no posee actividad $\beta$-glucuronidasa, los serotipos de STEC no-O157 no presentan marcadores fenotípicos diferenciales comparados con las $E$. coli comensales. Por lo tanto, para su identificación se requiere la aplicación de estrategias más complejas, como: serotipificación, adherencia a células HEp-2, ensayo de FAS (por sus siglas es inglés fluorescent actin staining), diferentes técnicas de biología molecular para amplificar genes que codifican factores de virulencia específicos, entre otras.

\section{2.- Reservorios y vías de transmisión de STEC}

A diferencia de lo que ocurre con las infecciones causadas por otras cepas de $E$. coli enteropatógeno, aquellas asociadas a STEC poseen un carácter zoonótico demostrado. Aunque la mayoría de los animales son portadores asintomáticos de STEC, se reportaron casos de diarrea en terneros, cerdos, perros y gatos (Abaas y 
col., 1989; Hammermueller y col., 1995). Por ejemplo, la enfermedad de los edemas del cerdo es causada por una variante específica de STEC (Frydendahl, 2002; Zweifel y col., 2006).

Los rumiantes en general, y el ganado vacuno en particular, son los principales reservorios de STEC. Sin embargo, en diferentes estudios de investigación se demostró que pueden encontrarse cepas de STEC en el tracto gastrointestinal de animales domésticos como ovejas, cabras, búfalos, cerdos, perros y gatos (Beutin y col., 1993; Caprioli y col., 2005; Bentancor y col., 2007; Oliveira y col., 2007). También pueden encontrarse cepas de STEC en animales de vida silvestre (Leotta y col., 2006).

En distintos países, entre los que se incluye a la Argentina, se realizaron numerosos estudios sobre la prevalencia de STEC que permitieron confirmar el rol del ganado vacuno como principal reservorio, aunque resulta difícil realizar comparaciones entre dichos estudios por las diferencias en las metodologías utilizadas y el muestreo (Ørskov y col., 1987; Wells y col., 1991; Beutin y col., 1993; Chapman y col., 1993; Cimolai y col., 1994; Parma y col., 2000; Meichtri y col., 2004; Masana y col., 2010; Masana y col., 2011).

Tanto el ganado de carne como el ganado lechero es portador de STEC. En un estudio realizado en nueve plantas de faena de la Argentina, se obtuvo una prevalencia de STEC 0157 de $4,1 \%$ en muestras de materia fecal y de $2,6 \%$ en muestras de carcasa bovina, mientras que la prevalencia de STEC no-O157 fue de 22,3\% y $9 \%$, respectivamente (Masana y col., 2010; Masana y col., 2011). E. coli O157:H7 no es patógena para el ganado, con excepción de casos en neonatos bovinos (Dean-Nystrom y col., 1997), la colonización es transitoria, de menos de 2 
meses de duración, y la portación fecal es más frecuente en el ganado joven (2 a 24 meses) que en el ganado adulto, lo cual se debería a una mayor susceptibilidad a la colonización. Se ha propuesto que la utilización de granos para engordar rápidamente al ganado en sistemas de cría intensiva es un factor que favorece al patógeno. Sin embargo, la evidencia científica sobre la controversia entre la alimentación con granos o pastos no es concluyente (Hovde y col., 1999).

La principal vía de transmisión (Figura 1) de STEC son los alimentos contaminados, como por ejemplo, carne molida, productos cárnicos crudos o insuficientemente cocidos, hamburguesas, embutidos fermentados, morcilla, leche no pasteurizada ni hervida, yogur, quesos, papas, lechuga, brotes de soja y rábano, jugos de manzana no pasteurizados, y agua, entre otros (Kaper y col., 2004; Caprioli y col., 2005).

La contaminación de los alimentos se debe principalmente al contacto con las heces de los animales. El consumo de carne molida o hamburguesas mal cocidas es la principal causa de infección por STEC. Durante la faena se contamina la superficie de la res, y en el procesamiento se transfiere la contaminación bacteriana al interior de la carne, donde los microorganismos pueden resistir una cocción insuficiente. En la Argentina, se detectó un 8,4\% de STEC no-O157 en hamburguesas congeladas (Gómez y col., 2002); un 6,8\% de STEC 0157:H7 en hamburguesas crudas y cocidas (Chinen y col., 2009); y un 13,2\% de STEC en productos cárnicos a nivel de boca de expendio (Jure y col., 2010).

STEC es resistente a los ácidos y puede sobrevivir en alimentos fermentados y vegetales frescos. En estos últimos, la contaminación se debe a la fertilización de los cultivos con materia fecal animal utilizada como abono, o posiblemente también 
durante la cosecha o procesamiento de los mismos, ya que se observó la presencia de los microorganismos en el interior del producto.

Otras formas de transmisión (Figura 1) incluyen la contaminación cruzada durante la preparación de los alimentos, el contacto directo del hombre con los animales, y persona a persona por la ruta fecal-oral. Es importante destacar que la dosis infectiva capaz de ocasionar enfermedad por parte de este grupo bacteriano es menor a 100 bacterias.

El tratamiento térmico es el método recomendado para asegurar la eliminación de STEC de los alimentos. La temperatura de pasteurización de la leche $\left(72^{\circ} \mathrm{C}\right.$ durante $\left.16,2 \mathrm{seg}\right)$ es un método efectivo para eliminar $10^{4}$ células de $E$. coli O157:H7 por mililitro. En los alimentos cárnicos una temperatura interna de $63^{\circ} \mathrm{C}$, constituye un punto crítico de control para asegurar la inactivación de $E$. coli 0157:H7. Sin embargo, la Administración de Alimentos y Drogas (FDA, por sus siglas en inglés Food and Drug Administration) de EE.UU. recomendó incrementar la temperatura de cocción de las hamburguesas a $68,3^{\circ} \mathrm{C}$ después de un brote que abarcó cinco estados y afectó a más de 700 personas en ese país (Griffin y col., 1994).

La contaminación fecal del agua puede deberse a la descarga de materia fecal en aguas de recreación o agua de bebida sin tratamiento previo. En Argentina se aisló E. coli O157:H7 en el Río de La Plata, en áreas cercanas a las tomas de agua para consumo humano (López y col., 1998). Además, se analizaron 2 brotes de diarreas por STEC, asociados con aguas recreacionales (Miliwebsky y col., 2007). A pesar que E. coli $0157: \mathrm{H} 7$ es susceptible al agua clorada, cuando el 
mantenimiento de las piscinas con desinfectantes es insuficiente, pueden llegar a ocurrir brotes debido a un ineficiente sistema de control.

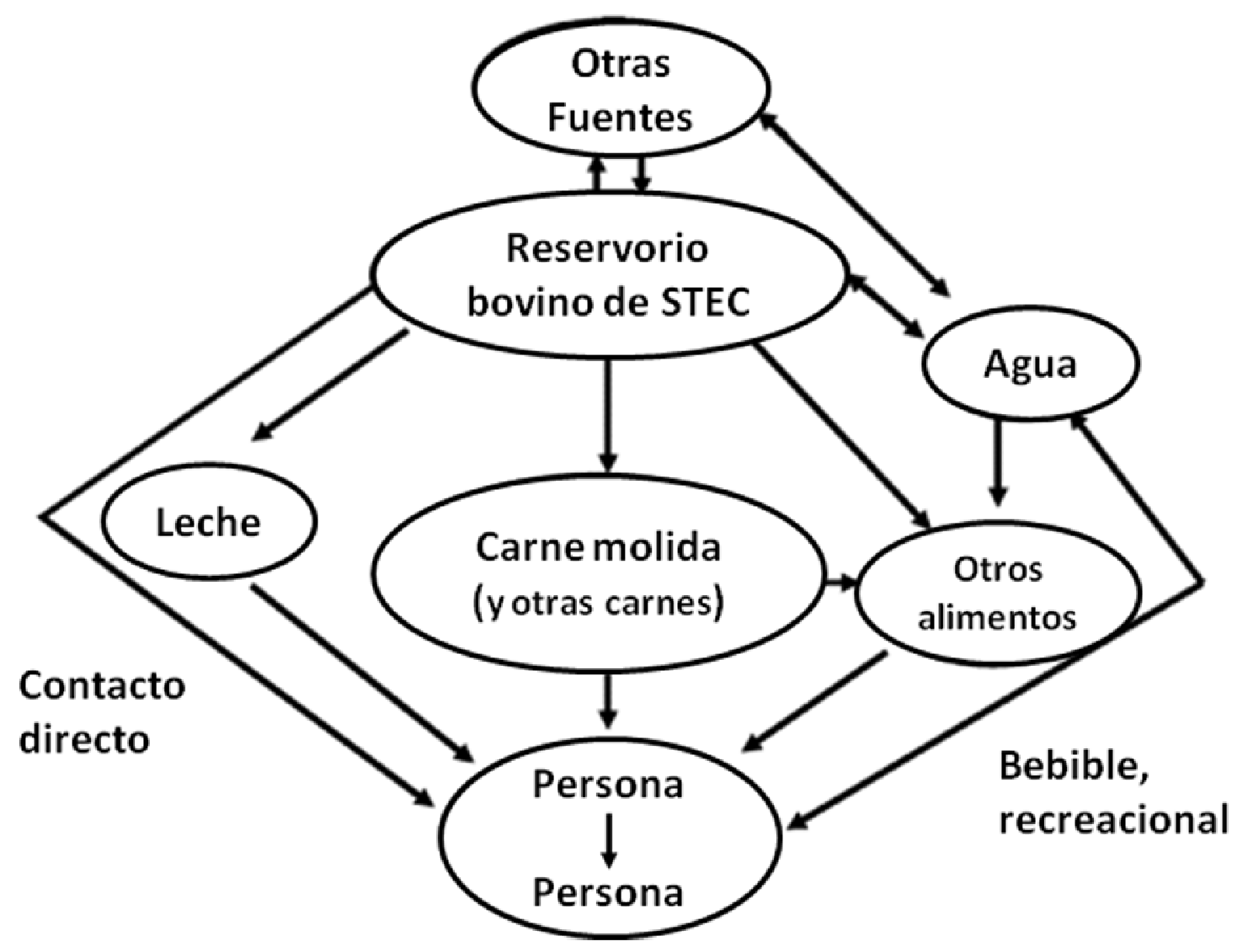

Figura 1. Vías de transmisión de STEC. La principal vía de transmisión de STEC la constituyen los alimentos contaminados. Otras formas de transmisión incluyen la contaminación cruzada durante la preparación de los alimentos, el contacto directo del hombre con los animales, y persona a persona por la ruta fecal-oral. Gyles (2007).

\section{3.- Manifestaciones clínicas de la infección por STEC}

La infección por STEC puede resultar en la portación asintomática del micoorganismo; casos esporádicos o brotes de diarrea (D); $\mathrm{CH} \circ \mathrm{SUH}$, una complicación sistémica severa caracterizada por insuficiencia renal aguda, anemia 
hemolítica microangiopática y trombocitopenia (Kaper y col., 2004). Los riñones constituyen el principal órgano afectado, pero también otros órganos como el páncreas, los pulmones, el corazón y el sistema nervióso central pueden resultar afectados.

La infección y desarrollo de la enfermedad puede ocurrir luego de la ingesta de una pequeña dosis bacteriana (tan baja como 50 unidades formadoras de colonias, UFC). El período de incubación promedio de la infección por STEC es de 3 días (con un rango de 1-8 días). Luego de ese período, un alto porcentaje de pacientes presenta diarrea acuosa y aproximadamente el 30\% (80\% en Argentina) evoluciona a diarrea sanguinolenta (DS) $\circ \mathrm{CH}$ en los días 5-6, presentando evidencia de edema de la mucosa colónica, dolores abdominales severos (frecuente en niños mayores), en algunos casos pueden presentarse vómitos e irritabilidad, pero no es frecuente la aparición de fiebre. Aunque en la mayoría de los casos la diarrea por STEC es autolimitada, aproximadamente del 5 al $10 \%$ de los niños infectados evolucionan a SUH, para el cual no existe un tratamiento específico, sino de sostén. Aproximadamente la mitad de los pacientes con SUH requiere diálisis y el 75\% requiere transfusión sanguínea (Rivas y col., 2011).

Entre los factores predictivos de evolución a SUH se incluyen: edades extremas (Cimolai y col., 1994; Buteau y col., 2000), leucocitosis (Bell y col., 1997; Buteau y col., 2000), tratamiento con agentes reductores de motilidad o antidiarreicos (Cimolai y col., 1994; Bell y col., 1997), fiebre (Bell y col., 1997), período prodrómico corto (Buteau y col., 2000), y en algunos casos diarrea sanguinolenta (Carter y col., 1987). El genotipo de la toxina de la cepa virulenta también influye en la evolución a SUH (Ostroff y col., 1989). 
En algunos pacientes, los síntomas de SUH aparecen 6-8 días después del inicio de la diarrea e incluyen: anemia hemolítica microangiopática (hematocrito $<30 \%)$, trombocitopenia $\left(<150.000\right.$ plaquetas $\left./ \mathrm{mm}^{3}\right)$, e isuficiencia renal aguda $(>1$ $\mathrm{mg} / \mathrm{dl}$ ). En otros pacientes, puede observase un período de silenciamiento entre la diarrea y la aparición de SUH; mientras que en otros pacientes el SUH aparece conjuntamente con el período de diarrea. En una proporción muy baja de casos de SUH no existe diarrea prodrómica (Tarr y col., 2005).

Esta enfermedad sindrómica puede presentar dos formas, una típica de etiología infecciosa, precedida por un período prodrómico con diarrea, generalmente sanguinolenta y de características endemoepidémicas (D+); y otra forma atípica (D-) desencadenada por varios factores, como drogas, transplantes de órganos, post parto, entre otros. STEC fue reconocido como agente causal de la forma infecciosa de SUH (Kaplan y col., 1990) y fueron Karmali y col. (1983) quienes reportaron la asociación entre SUH y cepas de STEC.

En los últimos años, el diagnóstico precoz de la enfermedad y el mejor manejo de la insuficiencia renal aguda y de la anemia disminuyó la letalidad durante el período agudo, siendo en la actualidad del 3 al 5\%. Sin embargo, un $5 \%$ de niños con SUH desarrolla insuficiencia renal crónica, requiriendo en pocos años procedimientos dialíticos o transplante renal. Otro $20 \%$ continúa con microhematuria y grados variables de proteinuria, pudiendo desarrollar insuficiencia renal crónica terminal en lapsos variables que pueden llegar a décadas (Spizzirri y col., 1997). Esta patología implica grandes costos económicos para los sistemas de salud, lo cual tiene un impacto importante en los países en desarrollo. 


\section{4.- Estrategias de la infección por STEC}

\section{A) Patogénesis}

Al igual que con otras infecciones entéricas causadas por E. coli, el mecanismo de patogénesis consiste en la colonización del intestino y producción de daño al hospedador debido a la producción de toxina. Sin embargo, este es un mecanismo que involucra múltiples procesos y una compleja interacción entre factores bacterianos y del hospedador. Un resumen general de este proceso se puede observar en la Figura 2.

Durante la colonización, STEC sortea los mecanismos de defensa del hospedador para establecerse en el intestino. La acidez del tracto gastrointestinal constituye un importante mecanismo de defensa del hospedador, pero en general se puede decir que STEC es una bacteria ácido-resistente, permitiéndole la supervivencia al bajo pH del estómago (Large y col., 2005). La bacteria pasa a través del intestino delgado, donde se activan genes en respuesta a las señales ambientales.

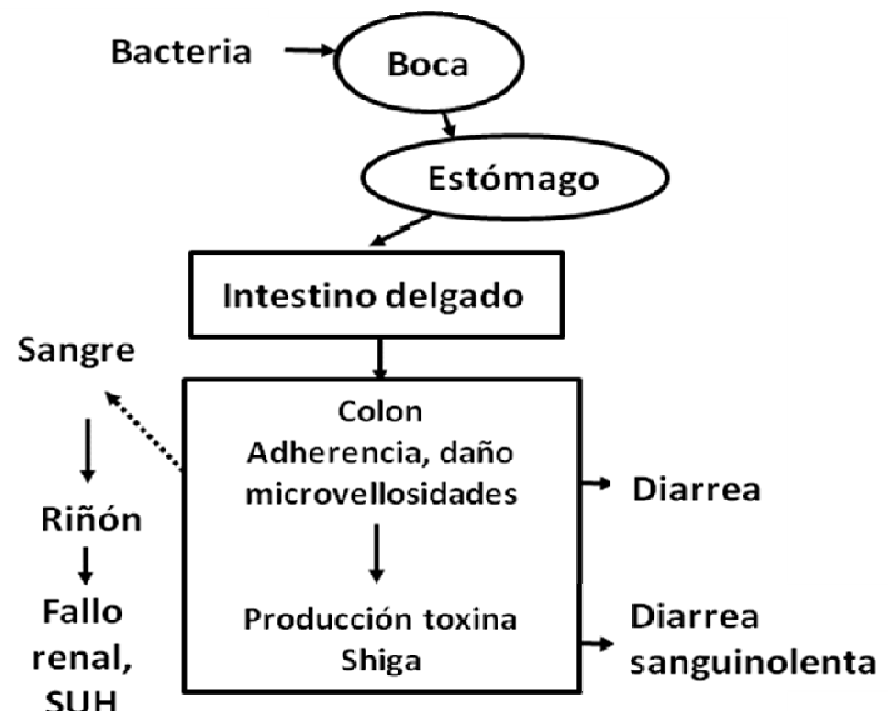

Figura 2. Visión general de la enfermedad en humanos producida por STEC. Gyles (2007). 
La adherencia a células epiteliales intestinales es una de las características de la infección por STEC y ha sido ampliamente investigada utilizando líneas de cultivos celulares e in vivo. El patrón de adherencia e interacción con células epiteliales es notablemente diferente entre las cepas STEC LEE-positivas y LEEnegativas. En las cepas LEE-positivas, la adherencia inicial es mediada por la fimbria polar larga (Lpf, por sus siglas en inglés Long polar fimbriae; ver abajo sección sobre Lpf), seguida por la producion de una histopatologia característica denominada lesión A/E (por sus siglas en inglés attaching and effacing), que involucra cambios estructurales en las células epiteliales y adherencia íntima de la bacteria al enterocito (Figura 3). Los cambios estructurales incluyen el barrido de las microvellosidades y la formación de pedestales, debido a la acumulación de filamentos de actina debajo de la membrana apical del enterocito. Los genes bacterianos requeridos para la formación de la lesión A/E se encuentran localizados en la isla de patogenicidad LEE, y están conservados en cepas EPEC y STEC capaces de inducir este tipo de lesión. Por el contrario, la adherencia de las cepas LEE-negativas no ha sido ampliamente investigada y sólo se realizaron trabajos puntuales para ciertos serotipos de STEC en los que no se observa la típica lesión A/E producida por las cepas LEE-positivas (Dytoc y col., 1994). 

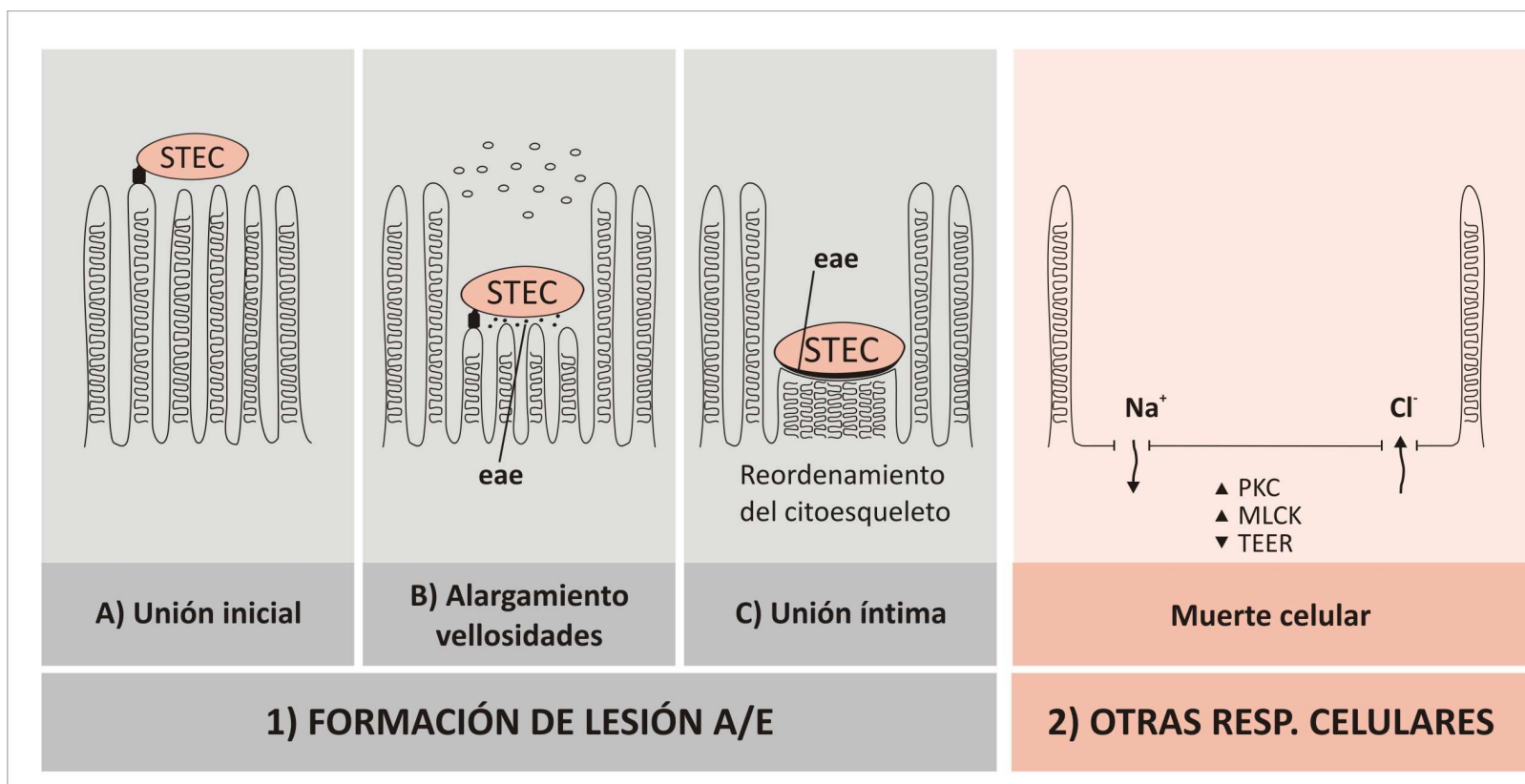

Figura 3. Representación gráfica de la colonización del epitelio intestinal por STEC $_{0157}$. Pasos característicos de la lesión A/E y otras respuestas celulares. Adaptado de Knutton y col. (1987).

La producción de toxina Shiga constituye el factor crítico en las enfermedades causadas por STEC. Si se produce suficiente Stx, los resultados frecuentes son diarrea sanguinolenta, debido al daño localizado de los vasos sanguíneos del colon. En cambio, si entra suficiente Stx a la circulación, los sitios endoteliales ricos en el receptor específico globotriaosilceramida (Gb3) de la toxina van a resultar dañados.

La toxina Shiga liberada se une mediante la subunidad B a la célula epitelial del intestino por interacción con el receptor específico Gb3 que se encuentra en la membrana apical. La toxina es luego internalizada en una vesícula endocítica y transportada al aparato de Golgi, donde la subunidad A es escindida proteolíticamente liberando el fragmento $\mathrm{A} 1$, el cual actúa sobre la subunidad ribosomal 28 S removiendo una adenina, lo que resulta en una inhibición irreversible de la síntesis proteica, provocando la muerte celular (Paton y Paton, 2006). 
La toxina puede también ser translocada desde la membrana apical a la superficie basolateral, con inducción de interleuquina-8 (IL-8), que contribuye a la acumulación de leucocitos en la pared intestinal. Se produce un daño en las células endoteliales de los vasos sanguíneos provocando diarrea sanguiolenta (Ray y Liu, 2001).

Stx entra a la circulación sanguínea y es transportada a distintos órganos blanco cuyas células endoteliales poseen el receptor Gb3. El lipopolisacárido (LPS) bacteriano y las citoquinas del huésped aumentan la sensibilidad a las Stx incrementando la disponibilidad de dichos receptores. En el riñón se encuentran altos niveles de Gb3, particularmente en la región cortical, donde se observan las principales lesiones en los pacientes con SUH. Las lesiones histopatológicas ocurren por interacción de la Stx con las células endoteliales de los vasos sanguíneos, éstas se hinchan y se desprenden a nivel del glomérulo. Simultáneamente, se produce un depósito de fibrina y de plaquetas en la microvasculatura renal, se oclusionan los capilares y se reduce el flujo sanguíneo, causando insuficiencia renal y ruptura de los glóbulos rojos. También se observan lesiones trombóticas, particularmente en la microvasculatura del intestino, cerebro y páncreas (Guth y col., 2011).

\section{B) Factores de virulencia}

Las toxinas Stx son consideradas el pricipal factor de virulencia de STEC, pero no las únicas responsables de la patogenicidad bacteriana completa. Tal es asi, que se describieron factores de virulencia adicionales, incluyendo adhesinas, proteasas, sistemas de captura de hierro, LPS, flagelos y otras toxinas, que podrían contribuir en la patogénesis de las mismas (Guth y col., 2011). 
La mayoría de los factores de virulencia/colonización se han descripto en aislamientos de E. coli O157:H7; sin embargo, es importante destacar el avance en el proceso de identificación y caracterización de factores de virulencia adicionales de cepas STEC no-O157.

\section{B.1.- Toxina Shiga}

Los miembros de la familia Stx poseen una estructura conservada de subunidades $\mathrm{AB}_{5}$, codificadas por bacteriófagos insertos en el cromosoma bacteriano. La subunidad A (33 kDa) es la parte biológicamente activa y la subunidad pentamérica B (7,5 kDa cada monómero), es la responsable de la unión de la toxina al receptor celular específico Gb3 (O’Brien y Holmes, 1987).

Las Stx se pueden clasificar según sus secuencias aminoacídicas en dos grandes grupos, Stx1 y Stx2. Cada uno de estos grupos a su vez posee un creciente número de variantes. El grupo de las Stx1 está compuesto por los subtipos Stx1a, que es idéntica a Stx de S. dysenteriae tipo 1; Stx1c (Zhang y col., 2002); y Stx1d (Bürk y col., 2003). A pesar que Stx1 y Stx2 poseen el mismo mecanismo de acción, comparten sólo un 55\% de similitud en la secuencia aminoacídica. El grupo de las Stx2 es más heterogéneo, y comprende a los subtipos Stx2a (O’Brien y col., 1984), Stx2b (Melton-Celsa y col., 1996; Pièrard y col., 1998), Stx2c (Schmitt y col., 1991), Stx2d (Kokai-Kun y col., 2000), Stx2e (Weinstein y col., 1988), Stx2f (Schmidt y col., 2000) y Stx2g (Leung y col., 2003). Las cepas STEC de origen humano, animal o de alimentos pueden producir variantes de Stx1 y Stx2, solas o combinadas. Si bien los miembros de la familia de Stx muestran similitud en su estructura y función, cada uno de los subtipos presenta grandes diferencias en su toxicidad in vitro e in vivo. Con lo que a esto respecta, se ha demostrado que Stx2 tiene una actividad 
citotóxica de 100 a 1000 veces superior a Stx1 (Tesh y col., 1993). Más aún, las cepas productoras de Stx2a, Stx2c y Stx2d fueron asociadas con mayor frecuencia a casos de $\mathrm{CH}$ y $\mathrm{SUH}$, cuando se compararon con otros subtipos de Stx1 y Stx2 (Schering y col., 2008). Por lo tanto, la caracterización de stx posee un importante valor predictivo de evolución a SUH en un paciente infectado por STEC (Friedrich y col., 2002).

\section{B.2.- Otras toxinas}

En la última década se descubrió un nuevo miembro de la familia de las toxinas CDT (por sus siglas en inglés cytolethal distending toxin), denominada CDT-V, en cepas STEC O157 y no-O157 asociadas a casos de SUH (Janka y col., 2003, Bielaszewska y col., 2004). Estudios de su posible función revelaron que la toxina daña el ADN eucariota, conduciendo a un arresto del ciclo celular en G2/M y posterior muerte celular (Bielaszewska y col., 2005). Estos datos demuestran que la proteína CDT-V daña directamente las células endoteliales y por lo tanto podría contribuir al desarrollo de SUH.

Un nuevo miembro de la familia de toxinas de tipo $A B_{5}$, denominada subtilasa, se descubrió por primera vez en una cepa STEC O113:H21 causante de un brote de SUH en Australia (Paton y col., 2004). Se realizaron numerosos estudios de prevalencia de los genes subAB en cepas STEC de un gran número de serotipos de diferentes países. Sin embargo, sólo se encontró en un subgrupo de cepas STEC LEE-negativas y en ciertos casos se puede ver asociada a cdt-V (Cergole-Novella y col., 2007; Galli y col., 2010a). Esta nueva toxina está compuesta por una subunidad A enzimáticamente activa, que es una serin-proteasa tipo subtilasa; y una subunidad B, que está relacionada a una posible proteína de exportación de Yersinia pestis. La 
inyección intraperitoneal de SubAB en ratones causa una extensiva trombosis de la microvasculatura, y necrosis de los riñones, el hígado y el cerebro (Paton y col., 2004), semejantes a las lesiones observadas en los pacientes con SUH, y por lo tanto sugiriendo la contribución de esta toxina a la patogénesis de las cepas STEC.

La toxina estable al calor de E. coli enteroagregativo, EAST1 (por sus siglas en inglés enteroaggregative E. coli heat-stable toxin 1) se identificó por primera vez en una cepa EAEC aislada de un niño con diarrea en Chile (Savarino y col., 1991). Está codificada por el gen astA, que se lo puede encontrar de forma cromosomal y/o plasmídica, en una o más copias. EAST1 fue asociada con otros patotipos de E. coli además de EAEC, como STEC, ETEC, DAEC y EPEC; y también con Salmonella. Se aislaron cepas EAST1-positivas tanto de humanos como de animales sanos o enfermos (Veilleux y Dubreuil, 2005), sin embargo se vio asociada comúnmente con el ganado bovino y porcino.

\section{B.3.- Factores de adherencia intestinal}

\section{Codificados dentro la región LEE}

\section{B.3.1.- Intimina como factor clave de colonización}

Además de los genes stx, las cepas STEC más virulentas poseen el gen eae, que codifica para la proteína de membrana externa intimina. El gen eae se encuentra codificado en la isla de patogenicidad LEE, la cual contiene 41 genes organizados en 5 operones polisitrónicos denominados LEE1, LEE2, LEE3, LEE4 y LEE5 (Figura 4). Esta compleja isla de $35,6 \mathrm{~kb}$ se encuentra estrictamente regulada y contiene todos los genes necesarios para la formación de la lesión A/E (explicada anteriormente). Los operones LEE1, LEE2 y LEE3 codifican los genes de las proteínas del sistema de secreción tipo III (SSTT) que forman el complejo de aguja. 
En el LEE4 se codifican los genes de las proteínas que se secretan a través del SSTT, las cuales se conocen de forma colectiva con el nombre de Esp (del inglés, $E$. coli secreted proteins). En el operón LEE5 se encuentran codificados los genes de las proteínas del sistema de adherencia propiamente dicho, la intimina y su receptor Tir (del inglés, translocated intimin receptor) (Castillo y col., 2005).

El aparato secretor consiste en una estructura molecular tipo aguja que comienza en el interior del citoplasma bacteriano, atraviesa las membranas interna y externa, y pasa a través de la membrana celular del hospedador. Las proteínas secretadas son transferidas desde el citoplasma bacteriano hasta la célula hospedadora a través de esta estructura, tal como ocurre con la proteína Tir, la cual es translocada por la bacteria a la célula hospedadora. Una vez allí, se inserta en la membrana plasmática exponiendo su región extracelular que funciona como receptor de la intimina (Kaper y col., 2004).

Aunque el papel esencial de la intimina y Tir es la unión íntima de la bacteria a los enterocitos y se haya reportado que cepas STEC O157:H7 mutantes para la intimina o Tir no sean capaces de colonizar el intestino en el modelo de infección de conejo (Ritchie y col., 2003), la presencia de la región LEE no sería esencial para la patogénesis, dado que un gran número de cepas STEC LEE-negativas son capaces de causar enfermedad severa y ocasionalmente brotes (Paton y col., 1999; Bielaszewska y col., 2011). Por lo tanto, en estas cepas otros factores de adherencia adicionales estarían involucrados en la patogénesis. 


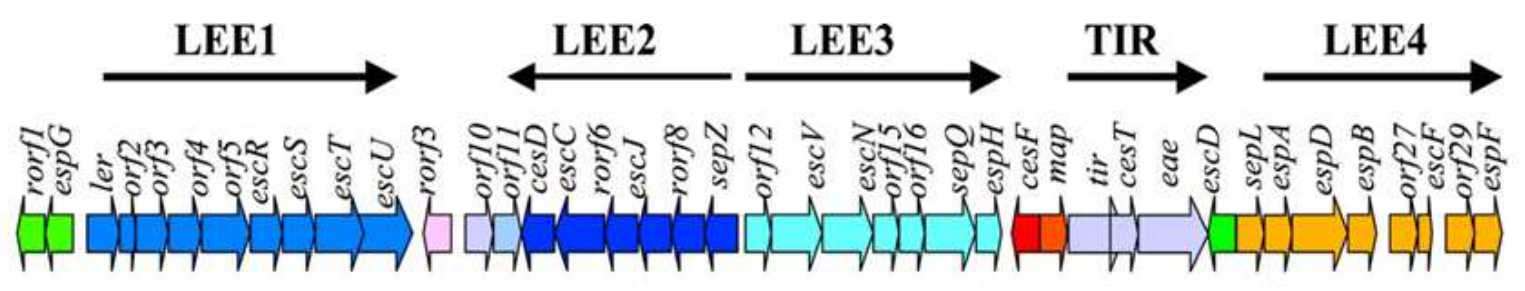

Figura 4. Organización de la isla de patogenicidad LEE. Castillo y col. (2005).

\section{Codificados fuera de la región LEE}

\section{B.3.2.- Fimbria polar larga (Lpf)}

A partir del análisis de secuencia del ácido desoxirribonucleico (ADN) de cepas O157:H7 se encontraron dos locus estrechamente realcionados con el operón Lpf de Salmonella enterica serovar Typhimurium (Baümler y Heffron, 1995). El primero, denominado Ipf1, se encuentra inserto entre las regiones intergénicas yhjX-yhjW (en relación al cromosoma de E. coli K-12) y está localizado en una isla de patogenicidad de $\mathrm{O} 157$ denominada $\mathrm{Ol}-141$, por lo cual en un comienzo recibió el nombre de Ipfol-154. El mismo posee seis genes $\left(I p f A B C C^{\prime} D E\right)$ similares en secuencia y orden a los de Salmonella, salvo que el gen IpfC se encuentra truncado (Torres y col., 2002). La expresión del operón Ipf1 en una cepa de E. coli no fimbriada (ORN172) reveló una adherencia aumentada in vitro (Torres y col., 2002). Además, mediante mutagénesis de la principal subunidad fimbrial, IpfA1, tanto en cepas O157:H7 stx-positivas como stx-negativas, se vió que exhibían una capacidad de adherencia reducida in vitro y el patrón de adherencia era difuso en vez de localizado (Torres y col., 2002; Torres y col., 2004). En un estudio reciente se demostró que las cepas STEC O157:H7 presentan una adherencia elevada in vitro cuando las líneas celulares son pre-incubadas con proteínas de matriz extracelular (Farfan y col., 2011). Además se observó una reducción en el pegado de las cepas 
mediante mutación de la principal subunidad fimbrial de Lpf, utilizando anticuerpos específicos contra LpfA1, y mediante la adición de manosa (Farfan y col., 2011).

El segundo operón se denominó Ipf2, se encuentra localizado en una isla específica de 0157 denominada Ol-154, por lo cual al comienzo se lo denominó Ipf $f_{\mathrm{OI}-154}$, y se encuentra inserto entre la región intergénica glmS-pstS (Torres y col., 2004). A diferencia de Ipf1, el locus Ipf2 contiene 5 genes (IpfABCDD), pero carece de un gen homólogo de Ipf1E y en su lugar, IpfD está duplicado. Contrariamente de lo ocurrido con Ipf1, la expresión del operón Ipf2 en una cepa de E. coli no fimbriada reveló una adherencia disminuída in vitro, con aparición de finas estructuras tipo fimbrias en la superficie de la bacteria, pero diferentes estructuralmente a aquellas observadas cuando se clonó Ipf1. Sin embargo, la mutación de la principal subunidad fimbrial, IpfA2, resultó en una reducción en la adherencia inicial a células Caco-2, aunque la adherencia a células HeLa no se vió afectada (Torres y col., 2004).

En cepas no-O157 también se identificaron genes homólogos a lpf. Se encontró que una cepa de STEC O113:H21 exhibía una capacidad de adherencia reducida a células $\mathrm{CHO}-\mathrm{K} 1$ mediante ensayos de mutagénesis al azar (Doughty y col., 2002). Cuando los investigadores analizaron la secuencia, demostraron que la cepa tenía un operón Ipf compuesto de cuatro genes (IpfABCD), y con la misma localización de Ipf2 de STEC 0157:H7 (glmS-pstS), por lo que se lo distinguió con el nombre de Ipf $_{\mathrm{O} 113}$ (Doughty y col., 2002). La expresión del operón Ipf $f_{\mathrm{O} 13}$ en una cepa de $E$. coli no fimbriada (ORN103) reveló que las bacterias se adherían de forma localizada y al mutar la principal subunidad de la fimbria, $\operatorname{lpf} A_{0113}$, se observó que las 
cepas tenían menos capacidad de formar microcolonias, indicando que esta fimbria podría estar promoviendo las interacciones bacterianas (Doughty y col., 2002).

Para determinar el rol de Lpf en la patogénesis se realizaron diversos estudios en modelos animales de infección o ex vivo. En un estudio realizado por Jordan y col. (2004), se demostró que cepas O157:H7 con los genes IpfA1 y IpfA2 mutados eran recuperadas en menor proporción, y causaban menos lesión A/E que la cepa silvestre cuando eran inoculadas en ovejas y cerdos gnotobióticos (Jordan y col., 2004). En otro estudio realizado por Fitzhenry y col. (2006), se demostró mediante cultivo de órganos in vitro (IVOC, por sus siglas en inglés in vitro organ culture) que los operones Ipf median el tropismo intestinal de STEC $0157: \mathrm{H} 7$, reteniendo la adherencia a los folículos asociados al epitelio y extendiéndose además al intestino delgado.

Estudios posteriores realizados por Torres y col. (2007a) determinaron la contribución de Lpf en la colonización, mediante la inoculación experimental de corderos de 6 semanas de vida con cepas de E. coli O157:H7 mutantes para IpfA1, IpfA2, y para ambos genes (IpfA1 y IpfA2) (Torres y col., 2007a). A pesar que las cepas mutantes simple para IpfA, particularmente IpfA1, exhibieron una reducción en el número de bacterias recuperadas de la materia fecal de los corderos infectados, la doble mutante IpfA1 IpfA2 tuvo efectos mucho más pronunciados (Torres y col., 2007a). Sin embargo, la infección con la cepa silvestre y las mutantes de lpf en el sistema IVOC de corderos, reveló que tanto la cepa silvestre como la doble mutante para Ipf adherían preferentemente en el recto medio, pero también al duodeno, jejuno, ileon y el colon, indicando que la reducción en la persistencia no se debía a la falta de colonización del tracto gastrointestinal de los corderos (Torres y col., 2007a). 
Como se mencionó anteriormente, al encontrarse operones Ipf homólogos en otras cepas de E. coli, su rol en la patogénesis también fue investigado. Por ejemplo, las cepas E. coli enteropatógenas poseen un locus lpf homólogo al operón de Salmonella. El análisis de una cepa EPEC mutante en Ipf, no reveló cambios en la adherencia a células HeLa o células de biopsia intestinal humana mediante el sistema IVOC, comparado con la cepa silvestre, sugiriendo que este operón no es necesario para la adherencia de EPEC y la formación de lesión A/E in vitro (Tatsuno y col., 2006). Las cepas de E. coli enteropatógenas de conejo (RPEC, por sus siglas en inglés rabbit enteropathogenic $E$. coli) poseen 2 loci Ipf. El primero codifica para los genes IpfABCDE (Ipf $\left.f_{\mathrm{R} 141}\right)$, altamente homólogos a los genes Ipf1 de STEC

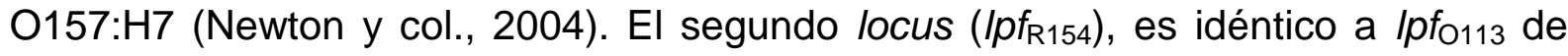
STEC 0113:H21. La mutación de los operones $l p f_{\mathrm{R} 141}$ y $l p f_{\mathrm{R} 154}$ no resultó en una adherencia disminuída a células en cultivo in vitro. Sin embargo, se produjo una significativa reducción en la severidad de la diarrea de los conejos (Newton y col., 2004).

La nomenclatura de Ipf es compleja debido a las diferentes designaciones de los mismos operones por distintos grupos de investigación. Por ejemplo, el locus Ipf1 también fue denominado Ipf $f_{0157 / 0 I-141}$ (Toma y col., 2006), Ipfo26 en cepas STEC O26:H11 (Bardiau y col., 2009), y lpf $f_{\mathrm{R} 141}$ en cepas REPEC (Newton y col., 2004). De igual manera, el locus Ipf2 fue denominado también como lpfo157/Ol-154 (Toma y col., 2006), Ipf $f_{\mathrm{O} 113}$ en cepas STEC 0113:H21 (Doughty y col., 2002), Ipf $f_{\mathrm{R} 154}$ en REPEC (Newton y col., 2004), y stg en APEC (Avian Pathogenic E. coli) (Lymberopoulos y col., 2006). Por lo tanto, con el fin de estandarizar la nomenclatura, en un estudio reciente se analizó la secuencia de ADN de distintos genes IpfA1 y IpfA2, y se 
identificaron algunos polimorfismos que permitieron clasificar la principal subunidad fimbrial en distintas variantes (Torres y col., 2009). Se describieron 5 tipos de IpfA1 (denominadas IpfA1-1, IpfA1-2, IpfA1-3, IpfA1-4 y IpfA1-5), y 3 tipos de IpfA2 (identificadas como IpfA2-1, IpfA2-2, y IpfA2-3). Las distintas variantes de IpfA1 y IpfA2 se asociaron con variantes específicas del gen eae (Torres y col., 2009). Sin embargo, en otro estudio posterior con una colección de cepas STEC LEEnegativas, no se pudo establecer asociación de alguna variante de IpfA y gravedad de la enfermedad (Galli y col., 2010b).

Cabe aclarar que la nomenclatura $I p f A_{0113}$ utilizada a lo largo del manuscrito se debe a que originalmente se llamaba de este modo, pero en realidad las cepas $I p f A_{0113}$-positivas pueden tener variantes diferentes de IpfA2.

\section{B.3.3.- Factor de E. coli enterohemorrágico para la adherencia}

Otra estrategia utilizada para la identificación de nuevos factores de adherencia es el análisis de aquellas cepas con una elevada capacidad de adherencia. En un estudio de mutagénesis mediada por transposones se identificó una cepa STEC O111:HNM con una elevada capacidad de adherencia a células $\mathrm{CHO}$ (Chinese hamster ovary), conduciendo a la identificación de un gen de 9.669 pb que codifica para una proteína de 365 kDa (Nicholls y col., 2000). Cuando se comparó la capacidad de adherencia de una cepa silvestre y aquella mutante para este gen, se observó una capacidad de adherencia reducida de la cepa mutante, pero el fenotipo de la lesión A/E permaneció siendo el mismo. A este gen se lo denominó factor de E. coli enterohemorrágico para la adherencia 1 (por sus siglas en inglés, enterohemorrhagic E. coli factor for adherence 1 o efa-1), y se lo encontró en cepas EPEC y STEC noO157 (Nicholls y col., 2000). En las cepas EPEC, se encontró que Efa-1 tenía un 
97,4\% de similitud con la proteína LifA (también denominada como linfostatina), que inhibe la proliferación de linfocitos y la síntesis de citoquinas pro-inflamatorias como IL-2, IL-4, IL-5, e interferón gamma (Klapproth y col., 2000; Abu-Median y col., 2006). Las cepas E. coli O157:H7 poseen una versión truncada del gen cromosomal efa-1, y algunos estudios sugieren que la proteína Efa-1 truncada podría llegar a tener algunas propiedades tales como las observadas para la proteína de tamaño completo (Stevens y col., 2004).

Un gen homólogo a efa-1/lifA también existe en el plásmido pO157 y se lo denominó toxB. La proteína ToxB exhibe un $28 \%$ de similitud aminoacídica con la proteína Efa-1/LifA y contribuye a la adherencia a células epiteliales intestinales (Tatsuno y col., 2001). Sin embargo, en estudios de modelo animal, se demostró que ToxB no es esencial para la colonización intestinal de ovejas y terneros (Stevens y col., 2004), y ninguna actividad del tipo linfostatina fue encontrada en cepas de $E$. coli O157:H7 (Abu-Median y col., 2006). Estudios recientes sugieren la presencia de un motivo o dominio que podría estar asociado a la adherencia celular, actividad de linfostatina o inducción de efectores del sistema de secresión tipo III en cepas STEC (Deacon y col., 2010). Por lo tanto, la determinación de función de ciertos domininos de las proteínas Efa-1/LifA/ToxB, serán útiles para entender las posibles funciones de estas proteínas versátiles en la patogénesis de cepas STEC.

\section{B.3.4.- Adhesina autoaglutinante de STEC}

Si bien se determinó el fenotipo de adherencia de algunas cepas STEC LEEnegativas (Paton y col., 2001), poco se conoce sobre los mecanismos reales en cuestión. La capacidad de adherencia de una cepa STEC O113:H21 (98NK2), LEEnegativa, causante de un brote de SUH en Australia, exhibió una capacidad de 
adherencia in vitro similar a cepas STEC LEE-positivas de referencia (Paton y col., 1999). Estudios posteriores sobre esa cepa determinaron la existencia de un megaplásmido que codifica para una proteína de 516 aa denominada Saa (por sus siglas en inglés STEC autoagglutinating adhesin), con un bajo porcentaje de similitud aminoacídica con la proteína YadA, una proteína extracelular plasmídica de Yersinia enterocolitica, implicada en adherencia a células epiteliales e invasión (Tamm y col., 1993); y Eib, una familia de proteínas de unión a inmunoglobulina de E. coli. La expresión de Saa en una cepa de E. coli (JM109) reveló una capacidad de adherencia aumentada a células HEp-2 respecto de la cepa silvestre y el patrón de adherencia resultó semi-localizado. La mutagénesis del gen saa en 98NK2, o la eliminación del megaplásmido a través de la técnica de curado, reflejó una reducción significativa en la capacidad de adherencia de la cepa. La proteína Saa producida por otras cepas STEC se diferencian en el tamaño (460 a 534 aa), como consecuencia de una variación en el número de repeticiones y/u otras inserciones o deleciones en el extremo 3’ (Paton y col., 2001). También se sugirío que las cepas STEC con un menor número de repeticiones, poseen una menor capacidad de adherencia a células HEp-2 que las cepas con genes saa de mayor tamaño (Paton y col., 2001). El gen saa se encontró en una amplia gama de fuentes y variedad de serotipos de cepas STEC LEE-negativas (Jenkins y col., 2003; Toma y col., 2004; Galli y col., 2010a), y fue propuesto como la posible adhesina de este tipo de cepas. Sin embargo, en estudios posteriores se demostró que cepas mutantes en este gen no mostraban una reducción en la capacidad de adherencia cuando eran comparadas con las cepas silvestres correspondientes (Toma y col., 2008). Inclusive, se observó que cepas de STEC saa-positivas exhibían diferentes 
propiedades de adherencia a células epiteliales que no podían atribuirse al número de repeticiones en el extremo C-terminal o a la expresión de Saa, sugiriendo que existen múltiples mecanismos de adherencia en las cepas saa-positivas (Toma y col., 2008).

\section{B.3.5.- Adhesina homóloga a IrgA}

Los mecanismos de adherencia de las cepas STEC sólo se encuentran parcialmente dilucidados. En la construcción de una biblioteca de ADN de E. coli O157:H7, se hallaron dos cósmidos que contenían un gen cromosomal que codificaba para una proteína similar a IrgA (por sus siglas en inglés iron regulated gene A) de Vibrio cholerae (Goldberg y col., 1992), y cuyo producto fue denominado Iha (por sus siglas en inglés IrgA homologue adhesin) (Tarr y col., 2000). La proteína Iha tiene un tamaño de $67 \mathrm{kDa}$ en $E$. coli $\mathrm{O} 157: \mathrm{H} 7$ y de $78 \mathrm{kDa}$ en cepas de $E$. coli de laboratorio. El gen iha fue encontrado en una amplia variedad de serotipos de cepas STEC e inclusive en cepas EXPEC, y se localiza adyacente al loci de resistencia a telurito.

La expresión de Iha en una cepa no fimbriada de $E$. coli reveló un patrón de adherencia difuso a células MDBK (por sus siglas en inglés Madin-Darby bovine kidney). Además, la mutación de iha en una cepa O157:H7 resultó en una reducción no significativa de la adherencia a células HeLa (Tarr y col., 2000). En un estudio posterior, se demostró la importancia de iha en la patogénesis de las infecciones urinarias, aunque se requieren más estudios que prueben la posible función de esta adhesina en cepas silvestres (Johnson y col., 2005). 


\section{B.3.6.- Fimbria de tipo 1}

La capacidad de una cepa patógena para unirse a la mucosa intestinal del hospedador es un paso crítico en la patogénesis de muchas infecciones bacterianas. Sin embargo, esta característica también está presente en cepas comensales, ya que necesitan adherirse y colonizar nichos específicos. Tanto cepas comensales como patogénas tienen posibles adhesinas que podrían participar en el proceso de adherencia. El ejemplo más estudiado son las fimbrias de tipo 1, que se pueden encontrar en la mayoría de las bacterias gram negativas, incluyendo E. coli, Salmonella spp., Klebsiella spp. y Vibrio cholerae. Estas fimbrias fueron las primeras en ser identificadas por su capacidad de aglutinar eritrocitos. Sin embargo, esta aglutinación puede ser inhibida por la presencia de manosa, fenómeno que se denominó aglutinación manosa-sensible o MSHA (por sus siglas en inglés mannosesensitive hemagglutination) (Edwards y Puente, 1998).

Las fimbrias de tipo 1 están codificadas por un cluster de genes fim, que incluyen al menos 9 genes requeridos para la biosíntesis, y están compuestas principalmente por FimA, la pricipal subunidad estructural. La función de adhesina manosa-sensible se la confiere una pequeña cantidad de la proteína FimH que se encuentra en la punta de la fimbria (Jones y col., 1995). La expresión de esta fimbria es variable dependiendo de la orientación de un elemento invertible de 314 pb localizado entre dos repeticiones invertidas de 9 pb (Abraham y col., 1985). Este elemento contiene el promotor que dirige la transcripción de los genes que codifican para las subunidades que componen la fimbria en una orientación (encendido), pero no en la otra (apagado) (Figura 5). Esta inversión es catalizada por dos recombinasas sitio-específicas, FimB y FimE, codificadas río arriba de este elemento 
invertible. FimB puede catalizar la inversión en ambas direcciones, tanto de encendido como de apagado de la expresión de la fimbria, mientras que FimE sólo puede catalizar la inversión en una dirección (de encendido a apagado) (McClain y col., 1991; Gally y col., 1996). El análisis de la secuencia nucleotídica del elemento invertible de cepas de E. coli 0157:H7 y 0157:HNM, reveló que poseen un deleción de 16 pb que hace que el estado de orientación sea el de apagado. Estos resultados sugieren que la expresión de la fimbria de tipo 1 esté regulada de forma diferente en distintos patógenos que causan infección entérica (lida y col., 2001).
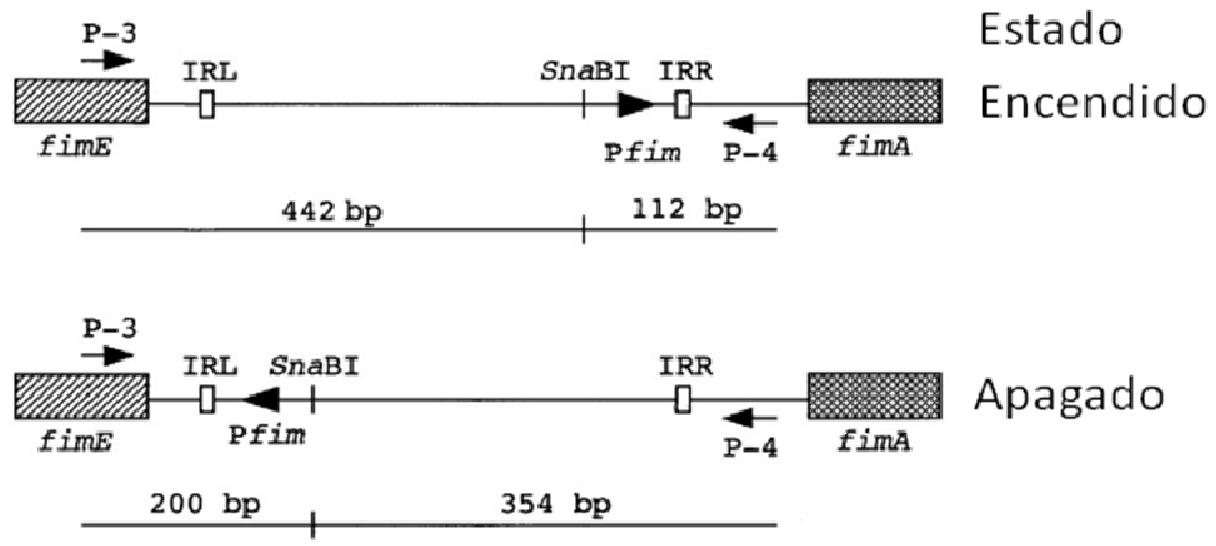

Figura 5. Orientación del elemento invertible que determina la variación de fase de la fimbria de tipo 1. Representación esquemática del promotor de fim mostrando los cebadores y sitios de restricción de SnaBI. La orientación puede determinarse por una PCR combinada con una restricción enzimática, ya que SnaBI corta simétricamente. IRL e IRR, repeticiones invertidas Izquierdas y derechas. lida y col. (2001).

\section{B.3.7.- Curli}

Las bacterias entéricas como E. coli y Salmonella spp. expresan fimbrias de origen proteico denominadas curli, que estan involucradas en la adherencia a superficies, contacto celular y formación de biopelículas (biofilms). Curli también media la 
adherencia e invasión celular al hospedador y son potentes inductoras de la respuesta inflamatoria del hospedador. También se demostró que curli puede promover la adherencia a células vegetales (Barnhart y Chapman, 2006). Bioquímicamente y estructuralmente, pertenecen a una clase creciente de fibras conocidas como amiloides.

Las bacterias que expresan curli presentan una coloración rojiza cuando son crecidas en placas suplementadas con el colorante rojo Congo $(\mathrm{RC})$, proveyendo un método fácil para identificar fenotípicamente la producción de curli (Collinson y col., 1993). Al menos 6 proteínas, codificadas por los operones $\operatorname{csg} B A$ y $\operatorname{csg} D E F G$, están involucradas en la formación de curli. Se identificaron operones homólogos en Salmonella spp., denominados agfBA y agfDEFG (Collinson y col., 1996; Römling y col., 1998). El operón csgBA codifica la subunidad estructural principal, CsgA y la proteína nucleadora CsgB. En ausencia de CsgB curli no se ensambla y la subunidad principal, CsgA, se secreta de la célula en una forma no polimerizada (Barnhart y Chapman, 2006). Sin embargo, CsgA y CsgB no necesitan ser expresadas por la mísma célula para que ocurra el ensamblado de curli, fenómeno denominado complementación interbacteriana. El operón csgDEFG codifica 4 proteínas accesorias requeridas para la formación de curli. La proteína CsgD actúa como regulador transcripcional positivo del operón $\operatorname{csg} B A$. CsgG es una lipoproteína de membrana externa requerida para la estabilidad y secresión de CsgA y CsgB. Cepas mutantes en $\operatorname{csg} G$ se observan de color blancas en las placas indicadoras de RC y no se observan fimbrias por microscopía electrónica. CsgE y CsgF son proteínas perplásmicas que interactúa con CsgG. Las mutantes en csgF presentan un fenotípo similar a las mutantes en $\operatorname{csg} B$ porque secretan CsgA de forma no 
polimerizada, presentando ambas una coloración rosada (Barnhart y Chapman, 2006).

La temperatura óptima de expresión de curli es por debajo de los $30^{\circ} \mathrm{C}$. Sin embargo, se demostró que también se puede expresar a 37ํㅡ. Los medios limitados en nutrientes y sal estimulan la expresión de curli y se observó que la expresión máxima se produce durante la fase estacionaria de crecimiento. Sin embargo, también se demostró que la expresión es dependiente de la cepa y de las condiciones ambientales del hospedador (Barnhart y Chapman, 2006).

\section{B.3.8.- Flagelos}

El rol de los flagelos en la adherencia y colonización intestinal de las cepas STEC continúa siendo controversial. En un comienzo, se observó que anticuerpos específicos contra el antígeno $\mathrm{H} 7$ no inhibían significativamente la adherencia in vitro de STEC O157:H7. Sin embargo, en otro estudio, la deleción del gen fliC de STEC O157:H7 causó una reducción significativa en la capacidad de adherencia de la cepa a células intestinales bovinas comparado con la cepa silvestre, sugiriendo que el flagelo $\mathrm{H} 7$ posee propiedades de adherencia (Erdem y col., 2007). Estudios adicionales, confirmaron que el flagelo $\mathrm{H} 7$ actúa como una adhesina sobre el epitelio intestinal bovino, admitiendo su participación en los primeros pasos de colonización del reservorio animal (Mahajan y col., 2009).

En ensayos in vivo, se demostró que el flagelo era necesario para la persistencia de una cepa de E. coli O157:H7 stx-negativa en el intestino de pollos SPF (por sus siglas in inglés specific pathogen free) (Best y col., 2005). Mientras que en estudios realizados en el modelo animal de ratón tratados con estreptomicina se observó que no existían diferencias a nivel de colonización intestinal en una cepa 
STEC 0113:H21 y su respectiva $\triangle$ fliC, pero la cepa mutante era menos virulenta que la cepa silvestre (Rogers y col., 2006). Estudios posteriores revelaron que una mutación del gen fli $_{\mathrm{H} 21}$ resultaba en una disminución significativa en la capacidad de invasión de la cepa STEC O113:H21, sugiriendo que FliC juega un rol importante en la infección de este grupo bacteriano, permitiéndole penetrar el epitelio intestinal (Luck y col., 2006). Sin embargo, el flagelo no debe cumplir un rol esencial en la patogénesis en humanos, ya que se encontraron cepas no móviles, como O157:HNM fermentadora de sorbitol, asociadas a casi el 40\% de casos de SUH en Alemania (Karch y Bielaszewska, 2001).

\section{5.- Situación actual del SUH en Argentina}

En Argentina, el SUH es endémico y constituye la primera causa pediátrica de insuficiencia renal aguda y la segunda de insuficiencia renal crónica. Además, es responsable del $20 \%$ de los transplantes renales en niños y adolescentes. Se producen alrededor de 500 casos nuevos por año con un importante subregistro, acumulándose más de 7.000 casos desde 1965 hasta el presente (Comité de Nefrología, 1995). Los niños afectados son menores de 5 años, fundamentalmente entre 6 y 36 meses, de ambos sexos y cualquier condición social (Rivas y col., 2011).

La enfermedad está distribuída en todo el país, pero la frecuencia es mayor en las provincias del centro y sur durante los meses cálidos, aunque se registran casos durante todo el año. La incidencia fue aumentando a través de los años, esto puede estar relacionado con el desconocimiento etiológico que imperó hasta hace pocos años, mientras que la letalidad disminuyó en los últimos años, debido al 
diagnóstico precoz de la enfermedad, la instauración temprana de la diálisis en los casos de oliguria severa o anuria y al manejo de la anemia hemolítica. En estudios realizados para establecer la etiología del SUH en niños argentinos (López y col., 1989; Rivas y col., 2011), se encontraron evidencias acumulativas de infección por STEC en el 60\% de los casos, siendo 0157:H7 el serotipo más frecuente. Shigella dysenteriae tipo 1, también asociada a casos de SUH en otros países, no fue aislada en nuestro país asociada a esta enfermedad.

La tasa de hospitalización para el año 2009 fue de 12 casos por cada 100.000 niños menores de 5 años. Se notificaron 487 casos de los cuales el 58,5\% correspondió al sexo femenino y una edad promedio de 37,0 \pm 49,5 meses. La mayoría de los casos ocurrieron durante los meses cálidos, en los períodos de enero a abril y de noviembre a diciembre. La letalidad en la fase aguda fue del 2,9\%. El Laboratorio de Referencia Nacional recibió muestras de 324 pacientes con diagnóstico de SUH, estableciéndose la infección por STEC en el 38,6\% de los mismos, por uno o más de los tres criterios diagnósticos utilizados (Fuente: Servicio Fisiopatogenia, INEI-ANLIS “Dr. C. G. Malbrán”).

\section{6.- Tratamiento}

Hasta el presente, no existe una terapia específica para las infecciones por STEC. Si bien, E. coli 0157 es susceptible a la mayoría de los agentes antimicrobianos utilizados comúnmente, aún no se confirmó que la antibioticoterápia aporte algún beneficio para el paciente. Por otra parte, algunos autores demostraron que dicho tratamiento puede precipitar la evolución a SUH. Por ejemplo trimetoprimasulfametoxazol estimula la liberación de Stx in vitro (Wong y col., 2000). Es por ello 
que se debe realizar una cuidadosa utilización de los antimicrobianos hasta que se demuestre la eficacia de los mismos mediante la realización de estudios de intervención controlados. Tampoco se deben usar agentes antidiarreicos, que disminuyen la motilidad intestinal, pues estudios retrospectivos señalan un riesgo aumentado de evolución a SUH.

El tratamiento comprende medidas terapéuticas destinadas a corregir las alteraciones hidroelectrolíticas, hematológicas, neurológicas o de hipertensión arterial durante el período agudo, y otras dirigidas a modificar la etiopatología de la enfermedad.

\section{7.- Control de STEC en el ganado bovino}

Como se mencionó anteriormente, el ganado bovino es considerado el principal reservorio y el origen de la infección por STEC para el hombre. Hasta el presente, las estrategias de intervención para evitar la contaminación de los productos cárnicos se centralizó en la playa de faena con la aplicación de prácticas que evitan la contaminación y proliferación de STEC. Actualmente, se considera que el control de STEC en el ganado bovino debe empezar dentro del establecimiento productor. Este podría ser uno de los puntos de intervención más importantes para disminuir la incidencia de infección en el hombre. Prebióticos, bacteriófagos, modificaciones en el manejo de los animales y nuevas formulaciones vacunales son algunas de las estrategias propuestas para el control de STEC en el ganado bovino (Mercado, 2006). La aplicación de estas estrategias puede contribuir a disminuir la incidencia de esta zoonosis. 


\section{OBJETIVOS}

\section{1.- Objetivo general}

Estudiar las adhesinas y los factores de adherencia putativos de cepas STEC LEEnegativas aisladas de ganado bovino destinado a consumo humano, con el objetivo de dilucidar posibles mecanismos de patogenia de este grupo bacteriano heterogéneo. Para ello nos planteamos estudiar centralmente dos aspectos: uno referido a conocer la prevalencia de adhesinas en cepas STEC LEE-negativas aisladas de bovinos y compararlas con cepas STEC LEE-negativas aisladas de humanos con diagnóstico de enfermedad por STEC; y el otro, consiste en establecer la capacidad de adherencia in vitro de un subgrupo bacteriano y desarrollar las bases para una estrategia alternativa de prevención.

Consideramos que el conocimiento de las moléculas implicadas en la fisiopatogenia bacteriana constituye la base racional para el desarrollo de estrategias preventivas viables.

\section{2.- Objetivos específicos}

Enmarcado dentro del objetivo general podemos elaborar dos objetivos específicos centrales:

\section{Objetivo A}

Conocer la prevalencia de las adhesinas en cepas STEC LEE-negativas aisladas de bovinos y humanos con diagnóstico de infección por STEC.

A.1.- Caracterizar las cepas en estudio mediante técnicas fenotípicas, genotípicas y de subtipificación molecular. 
A.2.- Identificar los genes que codifican para las adhesinas y los factores de adherencia putativos presentes en las cepas en estudio.

A.3.- Comparar el perfil de virulencia de las cepas en estudio y determinar las adhesinas más prevalentes entre las cepas de origen bovino y humano.

\section{Objetivo B}

Establecer la capacidad de adherencia in vitro de un subgrupo de cepas STEC LEE-negativas.

B.1.- Seleccionar las cepas STEC con perfiles de adhesinas únicos, y determinar su capacidad de adherencia in vitro.

B.2.- Obtener la cepa mutante negativa para la adhesina identificada como más prevalente.

B.3.- Desafiar líneas celulares con la cepa silvestre y su respectiva mutante negativa.

B.4.- Comparar los resultados obtenidos en el objetivo anterior. 


\section{MATERIALES Y METODOS}

\section{1.- Cepas bacterianas y plásmidos}

Se utilizaron 200 cepas pertenecientes a la colección del Servicio Fisiopatogenia del Instituto Nacional de Enfermedades Infecciosas - ANLIS "Dr. Carlos G. Malbrán”. Se estudiaron 153 cepas STEC no-O157, LEE-negativas, aisladas de materia fecal y carcasas bovinas durante los años 2005-2006, y 47 cepas STEC no-O157, LEEnegativas, aisladas de casos clínicos de infección humana durante los años 20012008 [SUH (n=19); D $(n=17) ;$ DS $(n=2) ;$ asintomáticos $(n=9)$ ]. El número de identificación, origen y características relevantes de las cepas bacterianas estudiadas se encuentran detalladas en el Anexo 1.

Los plásmidos utilizados en este estudio se encuentran listados en la Tabla 1.

Las cepas E. coli EDL933, O157:H7 (iha, efa1, toxB, IpfA1-3, IpfA2-2, csgA); 93-016, O113:H21 (IpfA2-1 [/pfA $A_{113}$ ], fimA, subAB, cdt-V); E2348/69, O127:H6 (eae, IpfA1-1); H30, O26:H11 (IpfA1-2); 344/09, O103:H2 (IpfA1-4); 136/05, O145:HNM (IpfA1-5); 883/05, O143:HNM (IpfA2-3); 434-1, O2:H8 (saa); EIEC C481 (astA) y E. coli K12 (JM109, Promega, Madison, WI, EE.UU.); fueron utilizadas como controles positivos y negativo, repectivamente.

La cepa STEC EH41 (O113:H21), EH41 $/$ pf $A_{0113}$ y el plásmido pWSK:Ipf (para complementar la mutante de $\left(p f A_{0113}\right)$, fueron proporcionados por la Dra. Elizabeth L. Hartland, Universidad de Melbourne, Australia.

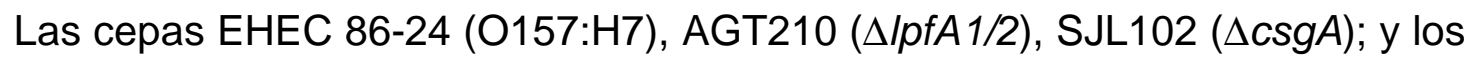
plásmidos pKD4 y pKM201 fueron proporcionados por el Dr. Alfredo G. Torres, 
Universidad de Texas Medical Branch, EE.UU. Todas las cepas se mantuvieron a $80^{\circ} \mathrm{C}$ en CTS con $40 \%$ de glicerol.

Las cepas utilizadas fueron identificadas por pruebas bioquímicas (Ewing y Edwards, 1986) y seroagrupadas según su antígeno somático (O) y flagelar $(\mathrm{H})$, con los antisueros, O1-0181 y H1-H56, preparados en el Instituto Adolfo Lutz de Brasil. Para la detección del antígeno O se utilizó la técnica de aglutinación en lámina con antisuero policlonal anti-O y para la detección del antígeno H se utilizó la técnica de aglutinación en tubo con antisuero anti-H (Ørskov y Ørskov, 1984). La capacidad de producción de toxina Shiga de las cepas STEC se determinó mediante ensayos de citotoxicidad específica en células Vero (Karmali y col., 1985).

\begin{tabular}{lll}
\hline Plásmidos & Características relevantes & Fuente/referencia \\
\hline pKM201 & $\begin{array}{l}\text { Plásmido helper red, derivado pMAK700, Amp }{ }^{r}, \\
\text { bajo número copia, origen de replicaión sensible } \\
\text { a la temperatura (crece a } 30^{\circ} \text { C) }\end{array}$ & Hamilton y col., 1989 \\
pWSK:Ipf & $\begin{array}{l}\text { Vector de clonación pWSK29, Amp', bajo número } \\
\text { copia, portando el operón IpfABCD } D_{\text {o113 }}\end{array}$ & Doughty y col., 2002 \\
pKD4 & $\begin{array}{l}\text { Plásmido templado para la amplificación por } \\
\text { PCR del cassette de kanamicina para la } \\
\text { recombinación mediada por lambda red. }\end{array}$ & Datsenko y Wanner, 2000 \\
\hline
\end{tabular}

Tabla 1. Plásmidos utilizados en este estudio.

\section{2.- Medios y condiciones de crecimiento bacteriano}

Todas las cepas fueron incubadas en atmósfera aerobia a $37^{\circ} \mathrm{C}$ en medio líquido 0 sólido, salvo cuando fuera indicada una restricción de temperatura. Los medios utilizados para el crecimiento bacteriano fueron caldo tripticasa de soja (CTS) o caldo Luria Bertani (LB). La formulación del caldo LB $(\mathrm{pH} 7,0)$ fue $10 \mathrm{~g}$ de triptona, 5 $\mathrm{g}$ de extracto de levadura, y $10 \mathrm{~g}$ de $\mathrm{NaCl}$ por litro de medio (Sambrook y col., 1989). Se adicionaron $15 \mathrm{~g}$ de bacto-agar por litro de caldo LB para preparar LB-agar. La 
formulación del CTS consistió en $30 \mathrm{~g}$ de tripticasa de soja por litro de medio (Becton Dickinson Co., Sparks, MD, EE.UU.). Se adicionaron $15 \mathrm{~g}$ de bacto-agar por litro de CTS para preparar agar tripticasa de soja (ATS). La triptona, el extracto de levadura, el $\mathrm{NaCl}$ y el bacto-agar fueron adquiridos de Fisher Scientific (Fair Lawn, NJ, EE.UU.).

El medio SOC (Sambrook y col., 1989) para electroporación se preparó con $20 \mathrm{~g}$ de triptona; $5 \mathrm{~g}$ de extracto de levadura; $0,5 \mathrm{~g}$ de $\mathrm{NaCl} ; 0,186 \mathrm{~g}$ de $\mathrm{KCl} ; 0,95 \mathrm{~g}$ de $\mathrm{MgCl}_{2} ; 1,20 \mathrm{~g}$ de $\mathrm{MgSO}_{4}$ y 3,6 $\mathrm{g}$ de glucosa por litro de medio.

Las placas indicadoras rojo Congo se prepararon a partir de LB-agar $\sin \mathrm{NaCl}$, $40 \mu \mathrm{g} / \mathrm{ml}$ de rojo Congo (MP Biomedicals Inc, Solon, OH, EE.UU.) y $20 \mu \mathrm{g} / \mathrm{ml}$ de azul brillante de Coomassie (Sigma-Aldrich Co., St. Louis, MO, EE.UU.).

Cuando fue necesario, tanto los medios líquidos como sólidos fueron suplementados con los siguientes antibióticos o compuestos: $50 \mu \mathrm{g} / \mathrm{ml}$ de kanamicina (Km); $100 \mu \mathrm{g} / \mathrm{ml}$ de ampicilina (Amp); $100 \mu \mathrm{g} / \mathrm{ml}$ de estreptomicina (Sm); $100 \mu \mathrm{g} / \mathrm{ml}$ de gentamicina $(\mathrm{Gm}) ; 0,5 \%$ de manosa (MP Biomedicals Inc., Solon, $\mathrm{OH}$, EE.UU.); $10 \mathrm{mg} / \mathrm{ml}$ de levadura (Calsa, Lanús, Argentina). Los antibióticos fueron adquiridos de Sigma-Aldrich Co. (St. Louis, MO, EE.UU.).

\section{3.- Líneas celulares y cultivo de células}

Se utilizaron las siguientes líneas celulares: HEp-2 (carcinoma de laringe), clon CRL 2102 de Caco-2 (adenocarcinoma de colon), T84 (carcinoma de colon). Todas las líneas celulares fueron incubadas a $37^{\circ} \mathrm{C}$ en presencia de $5 \% \mathrm{CO}_{2}$.

La línea celular HEp-2 fue mantenida en medio de Eagle modificado (MEM, por sus siglas en inglés modified Eagle's medium) (Gibco, Carlsbad, CA, EE.UU.), 
conteniendo $10 \%$ de suero fetal bovino (SFB) (Gibco, Carlsbad, CA, EE.UU.), 2 mM de L-glutamina, $10 \mathrm{mg} / \mathrm{l}$ de rojo de fenol (RF) y $1 \%$ de una mezcla de antibióticosantimicóticos (100 U penicilina base; $100 \mu \mathrm{g} \mathrm{Sm}$ base; 0,25 $\mu \mathrm{g} / \mathrm{ml}$ anfotericina B) (Gibco, Carlsbad, CA, EE.UU.). La línea intestinal CRL 2102 fue mantenida de forma indiferenciada en medio MEM (Gibco), conteniendo 20\% de SFB (Gibco), 2 mM de L-glutamina, $10 \mathrm{mg} / \mathrm{L}$ de RF y $1 \%$ de una mezcla de antibióticos/antimicóticos (Gibco). La línea intestinal T84 fue mantenida en medio de Eagle modificado por Dulbecco (DMEM, por sus siglas en inglés Dulbecco's modified Eagle's medium), más una mezcla de nutrientes de Ham F-12 (DMEM/F12 en una propoción 1:1) (Gibco, Carlsbad, CA, EE.UU.), conteniendo 10\% de SFB (Gibco); 2,5 mM de Lglutamina; $15 \mathrm{mM}$ de HEPES; $8,1 \mathrm{mg} / \mathrm{L}$ de RF y $1 \%$ de una mezcla de antibióticos/antimicóticos (Gibco).

\section{4.- Caracterización genotípica}

Se confirmó la portación del gen stx de las cepas productoras de toxina Shiga mediante la técnica de reacción en cadena de la polimerasa (PCR, por sus siglas en inglés polymerase chain reaction) múltiple, previamente validada por Leotta y col. (2005).

La subtipificación de los aislamientos se realizó por PCR, seguida de una restricción enzimática que genera fragmentos de largo polimórfico (PCR-RFLP, por sus siglas en inglés restriction fragment lenght polymorphism); y electroforesis en campo pulsado (PFGE, por sus siglas en inglés pulsed-field gel electrophoresis). Mediante PCR-RFLP se determinaron las variantes de $s t x_{1}$ y $s t x_{2}$ (Tyler y col., 1991; Pièrard y col., 1998; Zhang y col., 2002; Jelacic y col., 2003). El análisis de los 
fragmentos de macrorestricción generados por PFGE se realizó utilizando el protocolo estandarizado por PulseNet para E. coli O157:H7 (Ribot y col., 2006).

La identificación de las adhesinas y factores de virulencia adicionales se realizó por PCR utilizando las concentraciones de los cebadores (Operon, Huntsville, AL, EE.UU.) y las condiciones de amplificación que se detallan en la Tabla 2. Las reacciones de PCR se llevaron a cabo en un volumen final de $25 \mu$, conteniendo $1 \mu \mathrm{l}$ de sobrenadante de lisado bacteriano (ver aislamiento de ADN total, sección 3.4.1); $20 \mathrm{mM}$ Tris- $\mathrm{HCl}(\mathrm{pH}$ 8,4); $50 \mathrm{mM} \mathrm{KCl} ; 1,5-2 \mathrm{mM} \mathrm{MgCl}$; desoxinucleótidos trifosfato (dNTP) 0,1 mM cada uno (Invitrogen, Brasil); y $1 \mathrm{U}$ de Taq (Thermus aquaticus) ADN polimerasa recombinante (Invitrogen, Brasil). Para todas las reacciones de amplificación se utilizó un termociclador My Cycler $^{\mathrm{TM}}$ Thermal cycler (Bio-Rad Laboratories, Hercules, CA, EE.UU.).

Las condiciones individuales de algunas PCR se describen en las próximas secciones. 


\begin{tabular}{|c|c|c|c|c|c|c|}
\hline Nombre & Secuencia $\left(5^{\prime}-3^{\prime}\right)$ & Blanco(s) & $\begin{array}{l}\text { Programa } \\
\text { Amplificación }\end{array}$ & {$[\mu \mathrm{M}]$} & $\begin{array}{l}\text { Tamaño } \\
\text { Amplicón } \\
\text { (pb) }\end{array}$ & Referencia \\
\hline $\begin{array}{l}\text { stx1a } \\
\text { stx1b }\end{array}$ & $\begin{array}{l}\text { GAAGAGTCCGTGGGATTACG } \\
\text { AGCGATGCAGCTATTAATAA }\end{array}$ & $s t x_{1}$ & $\begin{array}{l}9^{\circ} \mathrm{C}, 5 \mathrm{~min}(1 \mathrm{ciclo}) ; 9^{\circ} \mathrm{C}, 30 \mathrm{seg}, 5^{\circ} \mathrm{C}, 30 \mathrm{seg}, \\
7^{\circ} \mathrm{C}, 30 \mathrm{seg}\left(30 \text { ciclos); } 72^{\circ} \mathrm{C}, 2 \mathrm{~min}(1 \mathrm{ciclo})\right.\end{array}$ & 2 & 130 & $\begin{array}{l}\text { Leotta y } \\
\text { col., } 2005\end{array}$ \\
\hline $\begin{array}{l}\text { stx2a } \\
\text { stx2b }\end{array}$ & $\begin{array}{l}\text { TTAACCACACCCCACCGGGCAGT } \\
\text { GCTCTGGATGCATCTCTGGT }\end{array}$ & $s t x_{2}$ & Idem $s t x_{1}$ & 0,4 & 346 & $\begin{array}{l}\text { Leotta y } \\
\text { col., } 2005\end{array}$ \\
\hline $\begin{array}{l}\text { KS7 } \\
\text { KS8 }\end{array}$ & $\begin{array}{l}\text { CCCGGATCCATGAAAAAAACATTATTAATAGC } \\
\text { CCCGAATTCAGCTATTCTGAGTCAACG }\end{array}$ & $s t x_{1 \mathrm{a}}, s t x_{1 \mathrm{c}}$ & $\begin{array}{l}9^{9} \mathrm{C}, 5 \mathrm{~min}(1 \mathrm{ciclo}) ; 9^{\circ} \mathrm{C}, 30 \mathrm{seg}, 5^{\circ} \mathrm{C}, 1 \mathrm{~min}, \\
7^{\circ} \mathrm{C}, 40 \mathrm{seg}\left(30 \text { ciclos); } 72^{\circ} \mathrm{C}, 2 \mathrm{~min}(1 \text { ciclo })\right.\end{array}$ & 0,6 & 282 & $\begin{array}{l}\text { Zhang y } \\
\text { col., } 2002\end{array}$ \\
\hline $\begin{array}{l}\text { VT2v-a } \\
\text { VT2v-b }\end{array}$ & $\begin{array}{l}\text { CATTCAGAGTAAAAGTGGCC } \\
\text { GGGTGCCTCCCGGTGAGTTC }\end{array}$ & $\begin{array}{l}s t x_{2 \mathrm{c}(\mathrm{vh}-\mathrm{a})}, s t x_{2 \mathrm{c}(\mathrm{vh}-\mathrm{b})} \\
s t x_{2 \mathrm{~b}-0118,},{ } x_{2 \mathrm{~b}-\mathrm{O} 3 \mathrm{a}}\end{array}$ & $\begin{array}{l}9^{9} \mathrm{C}, 5 \mathrm{~min}(1 \mathrm{ciclo}) ; 94^{\circ} \mathrm{C}, 30 \mathrm{seg}, 5^{\circ} \mathrm{C}, 30 \mathrm{seg} \\
7^{\circ} \mathrm{C}, 30 \mathrm{seg}\left(30 \text { ciclos); } 72^{\circ} \mathrm{C}, 2 \mathrm{~min}(1 \text { ciclo })\right.\end{array}$ & 0,4 & 385 & $\begin{array}{l}\text { Tyler y col., } \\
1991\end{array}$ \\
\hline $\begin{array}{l}\text { VT2v-c } \\
\text { VT2v-d }\end{array}$ & $\begin{array}{l}\text { AAGAAGATGTTTATGGCGGT } \\
\text { CACGAATCAGGTTATGCCTC }\end{array}$ & $\begin{array}{l}s t x_{2 a}, s t x_{2 c(v h-a)} \\
s t x_{2 c(v h-b)}\end{array}$ & $\begin{array}{l}9^{9} \mathrm{C}, 5 \mathrm{~min}(1 \mathrm{ciclo}) ; 94^{\circ} \mathrm{C}, 30 \mathrm{seg}, 5^{\circ} \mathrm{C}, 30 \mathrm{seg} \\
7^{\circ} \mathrm{C}, 30 \mathrm{seg}\left(30 \text { ciclos); } 72^{\circ} \mathrm{C}, 2 \mathrm{~min}(1 \mathrm{ciclo})\right.\end{array}$ & 0,6 & 285 & $\begin{array}{l}\text { Tyler y col., } \\
1991\end{array}$ \\
\hline $\begin{array}{l}\text { VT2v-e } \\
\text { VT2v-f }\end{array}$ & $\begin{array}{l}\text { AATACATTATGGGAAAGTAATA } \\
\text { TTAAACTGCACTTCAGCAAAT }\end{array}$ & $\begin{array}{l}s t x_{2 \mathrm{a}}, s t x_{2 \mathrm{c}(\mathrm{vh}-\mathrm{a})} \\
s t x_{2 \mathrm{c}(\mathrm{vh}-\mathrm{b})} s t x_{2 \mathrm{~b}-0118} \\
s t x_{2 \mathrm{~b}-\mathrm{O} 3 \mathrm{a}}\end{array}$ & $\begin{array}{l}94^{\circ} \mathrm{C}, 5 \mathrm{~min}(1 \mathrm{ciclo}) ; 94^{\circ} \mathrm{C}, 30 \mathrm{seg}, 5^{\circ} \mathrm{C}, 30 \mathrm{seg} \\
7^{\circ} \mathrm{C}, 30 \mathrm{seg}\left(30 \text { ciclos); } 72^{\circ} \mathrm{C}, 2 \mathrm{~min}(1 \mathrm{ciclo})\right.\end{array}$ & 1 & 348 & $\begin{array}{l}\text { Pièrard y } \\
\text { col., } 1998\end{array}$ \\
\hline $\begin{array}{l}\text { SLT-II-vc } \\
\text { CKS2 }\end{array}$ & $\begin{array}{l}\text { ACCACTCTGCAACGTGTCGC } \\
\text { ACTGAATTGTGACACAGATTA }\end{array}$ & $\begin{array}{l}s t x_{2 \mathrm{~d}}, s t x_{2 \mathrm{~d} 1(\mathrm{vh}-\mathrm{a})} \\
s t x_{2 \mathrm{~d} 2(\mathrm{vh}-\mathrm{b})}\end{array}$ & $\begin{array}{c}9^{\circ} \mathrm{C}, 5 \mathrm{~min}(1 \mathrm{ciclo}) ; 94^{\circ} \mathrm{C}, 30 \mathrm{seg}, 5^{\circ} \mathrm{C}, 90 \mathrm{seg} \\
7^{\circ} \mathrm{C}, 90 \mathrm{seg}\left(30 \text { ciclos); } 72{ }^{\circ} \mathrm{C}, 2 \mathrm{~min}(1 \mathrm{ciclo})\right.\end{array}$ & 2 & 890 & $\begin{array}{l}\text { Jelacic y } \\
\text { col., } 2003\end{array}$ \\
\hline $\begin{array}{l}\text { SK1 } \\
\text { SK2 }\end{array}$ & $\begin{array}{l}\text { CCCGAATTCGGCACAAGCATAAGC } \\
\text { CCCGGATCCGTCTCGCCAGTATTCG }\end{array}$ & eae & $\begin{array}{l}95^{\circ} \mathrm{C}, 5 \mathrm{~min}(1 \mathrm{ciclo}) ; 95^{\circ} \mathrm{C}, 30 \mathrm{seg}, 5^{\circ} \mathrm{C}, 1 \mathrm{~min}, \\
7^{\circ} \mathrm{C}, 2 \mathrm{~min}\left(30 \text { ciclos); } 72^{\circ} \mathrm{C}, 2 \mathrm{~min}(1 \mathrm{ciclo})\right.\end{array}$ & 0,4 & 864 & $\begin{array}{l}\text { Karch y } \\
\text { col., } 1993\end{array}$ \\
\hline $\begin{array}{l}\text { SAADF } \\
\text { SAADR }\end{array}$ & $\begin{array}{l}\text { CGTGATGAACAGGCTATTGC } \\
\text { ATGGACATGCCTGTGGCAAC }\end{array}$ & saa & $\begin{array}{l}93^{\circ} \mathrm{C}, 5 \mathrm{~min}(1 \mathrm{ciclo}) ; 9^{\circ} \mathrm{C}, 1 \mathrm{~min}, 5^{\circ} \mathrm{C}, 1 \mathrm{~min}, \\
72^{\circ} \mathrm{C}, 1 \mathrm{~min}\left(25 \text { ciclos); } 72^{\circ} \mathrm{C}, 2 \mathrm{~min}(1 \mathrm{ciclo})\right.\end{array}$ & 0,5 & 119 & $\begin{array}{l}\text { Toma y } \\
\text { col., } 2004\end{array}$ \\
\hline $\begin{array}{l}\text { iha-I } \\
\text { iha-II }\end{array}$ & $\begin{array}{l}\text { CAGTTCAGTTTCGCATTCACC } \\
\text { GTATGGCTCTGATGCGATG }\end{array}$ & iha & Idem saa & 0,5 & 1.305 & $\begin{array}{l}\text { Toma y } \\
\text { col., } 2004\end{array}$ \\
\hline $\begin{array}{l}\text { toxB.911F } \\
\text { toxB.1468R }\end{array}$ & $\begin{array}{l}\text { ATACCTACCTGCTCTGGATTGA } \\
\text { TTCTTACCTGATCTGATGCAGC }\end{array}$ & tox $B$ & Idem saa & 0,5 & 602 & $\begin{array}{l}\text { Toma y } \\
\text { col., } 2004\end{array}$ \\
\hline $\begin{array}{l}88 \mathrm{~T} 14 \\
88 \mathrm{~T} 9\end{array}$ & $\begin{array}{l}\text { GAGACTGCCAGAGAAAG } \\
\text { GGTATTGTTGCATGTTCAG }\end{array}$ & efa1 & Idem saa & 0,2 & 479 & $\begin{array}{l}\text { Toma y } \\
\text { col., } 2004\end{array}$ \\
\hline $\begin{array}{l}\text { IpfA-F } \\
\text { IpfA-R }\end{array}$ & $\begin{array}{l}\text { ATGAAGCGTAATATTATAG } \\
\text { TTATTTCTTATATTCGAC }\end{array}$ & Ipf $A_{0113}$ & $\begin{array}{c}9^{94^{\circ} \mathrm{C}, 2} 2 \min \left(1 \text { ciclo); } 9^{\circ} \mathrm{C}, 1 \mathrm{~min}, 5^{\circ} \mathrm{C}, 50 \mathrm{seg},\right. \\
7^{\circ} \mathrm{C}, 1 \mathrm{~min}\left(30 \text { ciclos); } 72^{\circ} \mathrm{C}, 2 \mathrm{~min}(1 \mathrm{ciclo})\right.\end{array}$ & 4 & 573 & $\begin{array}{l}\text { Toma y } \\
\text { col., } 2004\end{array}$ \\
\hline $\begin{array}{l}\text { LPFA1-AF } \\
\text { LPFA1-AR }\end{array}$ & $\begin{array}{l}\text { AGTTGGTGATAAATCACCAT } \\
\text { GTGCTGGATTCACCACTATTCATCG }\end{array}$ & IpfA1-1 & $\begin{array}{c}9^{\circ} \mathrm{C}, 5 \mathrm{~min}(1 \mathrm{ciclo}) ; 9^{\circ} \mathrm{C}, 30 \mathrm{seg}, 5^{\circ} \mathrm{C}, 30 \mathrm{seg} \\
72^{\circ} \mathrm{C}, 30 \mathrm{seg}(35 \mathrm{ciclos}) ; 72^{\circ} \mathrm{C}, 10 \mathrm{~min}(1 \mathrm{ciclo})\end{array}$ & 1 & 222 & $\begin{array}{l}\text { Torres y } \\
\text { col., } 2009\end{array}$ \\
\hline $\begin{array}{l}\text { LPFA1-B1F } \\
\text { LPFA1-B1R }\end{array}$ & $\begin{array}{l}\text { AAGTCTGTATTTACTGCTATG } \\
\text { GAAATACAGAACGGTCTGA }\end{array}$ & IpfA1-2 & $\begin{array}{c}9^{9}{ }^{\circ} \mathrm{C}, 5 \mathrm{~min}(1 \mathrm{ciclo}) ; 9^{\circ} \mathrm{C}, 30 \mathrm{seg}, 5^{\circ} \mathrm{C}, 30 \mathrm{seg} \\
7^{\circ} \mathrm{C}, 30 \mathrm{seg}\left(35 \text { ciclos); } 72^{\circ} \mathrm{C}, 10 \mathrm{~min}(1 \mathrm{ciclo})\right.\end{array}$ & 1 & 273 & $\begin{array}{l}\text { Torres y } \\
\text { col., } 2009\end{array}$ \\
\hline
\end{tabular}




\begin{tabular}{|c|c|c|c|c|c|c|}
\hline Nombre & Secuencia $\left(5^{\prime}-3^{\prime}\right)$ & Blanco(s) & $\begin{array}{l}\text { Programa } \\
\text { Amplificación }\end{array}$ & {$[\mu \mathrm{M}]$} & $\begin{array}{l}\text { Tamaño } \\
\text { Amplicón } \\
\text { (pb) }\end{array}$ & Referencia \\
\hline $\begin{array}{l}\text { LPFA1-CF } \\
\text { LPFA1-CR1 }\end{array}$ & $\begin{array}{l}\text { GGTTGGTGACAAATCCCCG } \\
\text { CGTCTGGCCTTTACTCAGA }\end{array}$ & IpfA1-3 & $\begin{array}{c}94^{\circ} \mathrm{C}, 5 \mathrm{~min}(1 \mathrm{ciclo}) ; 9^{\circ} \mathrm{C}, 30 \mathrm{seg}, 6^{\circ} \mathrm{C}, 30 \mathrm{seg} \\
72^{\circ} \mathrm{C}, 30 \mathrm{seg}\left(35 \text { ciclos); } 72^{\circ} \mathrm{C}, 10 \mathrm{~min}(1 \mathrm{ciclo})\right.\end{array}$ & 1 & 244 & $\begin{array}{l}\text { Torres y } \\
\text { col., } 2009\end{array}$ \\
\hline $\begin{array}{l}\text { LPFA1-B2F } \\
\text { LPFA1-B2R }\end{array}$ & $\begin{array}{l}\text { AAGTCTGTGTTTACCACTACT } \\
\text { AAAATACAGAACAGTCTGG }\end{array}$ & IpfA1-4 & $\begin{array}{c}9^{\circ} \mathrm{C}, 5 \mathrm{~min}(1 \mathrm{ciclo}) ; 9^{\circ} \mathrm{C}, 30 \mathrm{seg}, 5^{\circ} \mathrm{C}, 30 \mathrm{seg} \\
7^{\circ} \mathrm{C}, 30 \mathrm{seg}(35 \mathrm{ciclos}) ; 72^{\circ} \mathrm{C}, 10 \mathrm{~min}(1 \mathrm{ciclo})\end{array}$ & 1 & 273 & $\begin{array}{l}\text { Torres y } \\
\text { col., } 2009\end{array}$ \\
\hline $\begin{array}{l}\text { LPFA1-CF } \\
\text { LPFA1-CR1 }\end{array}$ & $\begin{array}{l}\text { GGTTGGTGACAAATCCCCG } \\
\text { GAGAACCGTCTGGCCTGTTT }\end{array}$ & IpfA1-5 & $\begin{array}{c}94^{\circ} \mathrm{C}, 5 \mathrm{~min}(1 \mathrm{ciclo}) ; 9^{\circ} \mathrm{C}, 30 \mathrm{seg}, 6^{\circ} \mathrm{C}, 30 \mathrm{seg} \\
72^{\circ} \mathrm{C}, 30 \mathrm{seg}\left(35 \text { ciclos); } 72^{\circ} \mathrm{C}, 10 \mathrm{~min}(1 \mathrm{ciclo})\right.\end{array}$ & 1 & 250 & $\begin{array}{l}\text { Torres y } \\
\text { col., } 2009\end{array}$ \\
\hline $\begin{array}{l}\text { LPFA2-B1F } \\
\text { LPFA2-B1R }\end{array}$ & $\begin{array}{l}\text { GGTAGTCTGGCGTCGCCACAGA } \\
\text { AATACGAATACCAACGCCG }\end{array}$ & IpfA2-1 & $\begin{array}{c}94^{\circ} \mathrm{C}, 5 \mathrm{~min}(1 \mathrm{ciclo}) ; 94^{\circ} \mathrm{C}, 30 \mathrm{seg}, 6^{\circ} \mathrm{C}, 30 \mathrm{seg} \\
72^{\circ} \mathrm{C}, 30 \mathrm{seg}\left(35 \text { ciclos); } 72^{\circ} \mathrm{C}, 10 \mathrm{~min}(1 \mathrm{ciclo})\right.\end{array}$ & 1 & 207 & $\begin{array}{l}\text { Torres y } \\
\text { col., } 2009\end{array}$ \\
\hline $\begin{array}{l}\text { LPFA2-CF } \\
\text { LPFA2-CR }\end{array}$ & $\begin{array}{l}\text { CTACAGGCGGCTGATGGAACA } \\
\text { GCTAATACCAGCGGCAGCATCGT }\end{array}$ & IpfA2-2 & $\begin{array}{c}9^{\circ} \mathrm{C}, 5 \mathrm{~min}(1 \mathrm{ciclo}) ; 9^{\circ} \mathrm{C}, 30 \mathrm{seg}, 7^{\circ} \mathrm{C}, 30 \mathrm{seg} \\
7^{\circ} \mathrm{C}, 30 \mathrm{seg}(35 \mathrm{ciclos}) ; 72^{\circ} \mathrm{C}, 10 \mathrm{~min}(1 \mathrm{ciclo})\end{array}$ & 1 & 297 & $\begin{array}{l}\text { Torres y } \\
\text { col., } 2009\end{array}$ \\
\hline $\begin{array}{l}\text { LPFA2-B2F } \\
\text { LPFA2-B2R }\end{array}$ & $\begin{array}{l}\text { GGTAGTCTGGCGTCACCACAGC } \\
\text { AATACGAATACCGACACCC }\end{array}$ & IpfA2-3 & $\begin{array}{c}9^{\circ} \mathrm{C}, 5 \mathrm{~min}(1 \mathrm{ciclo}) ; 94^{\circ} \mathrm{C}, 30 \mathrm{seg}, 5^{\circ} \mathrm{C}, 30 \mathrm{seg} \\
7^{\circ} \mathrm{C}, 30 \mathrm{seg}\left(35 \text { ciclos); } 72{ }^{\circ} \mathrm{C}, 10 \mathrm{~min}(1 \mathrm{ciclo})\right.\end{array}$ & 1 & 207 & $\begin{array}{l}\text { Torres y } \\
\text { col., } 2009\end{array}$ \\
\hline $\begin{array}{l}\text { east11a } \\
\text { east11b }\end{array}$ & $\begin{array}{l}\text { CCATCAACACAGTATATCCGA } \\
\text { GGTCGCGAGTGACGGCTTTGT }\end{array}$ & astA & Idem saa & 1 & 111 & $\begin{array}{r}\text { Yamamoto } \\
\text { y col., } 1996\end{array}$ \\
\hline $\begin{array}{l}\operatorname{csgAF} \\
\operatorname{csgAR}\end{array}$ & $\begin{array}{l}\text { TGGTAACAGCGCCACTCTTG } \\
\text { GACGGTGGAATTAGATGCAGTC }\end{array}$ & $\operatorname{csg} \mathrm{A}$ & $\begin{array}{l}94^{\circ} \mathrm{C}, 2 \mathrm{~min}(1 \mathrm{ciclo}) ; 94^{\circ} \mathrm{C}, 1 \mathrm{~min}, 6^{\circ} \mathrm{C}, 1 \mathrm{~min}, \\
72^{\circ} \mathrm{C}, 1 \mathrm{~min}\left(30 \text { ciclos); } 72^{\circ} \mathrm{C}, 10 \mathrm{~min}(1 \mathrm{ciclo})\right.\end{array}$ & 0,5 & 111 & $\begin{array}{l}\text { Lloyd y col., } \\
2012\end{array}$ \\
\hline $\begin{array}{l}\text { P3 } \\
\text { P4 }\end{array}$ & $\begin{array}{l}\text { GTGCATCGAAATATTCGCCATACT } \\
\text { AGTCGTTCTGTACACTTTGTTTTG }\end{array}$ & $\operatorname{fim} A$ & 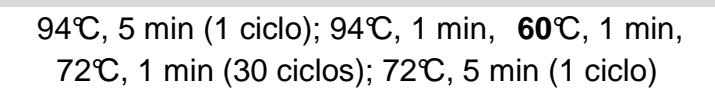 & 0,6 & 554 & $\begin{array}{l}\text { lida y col., } \\
\quad 2001\end{array}$ \\
\hline $\begin{array}{l}\text { subHCD F } \\
\text { subSCD R }\end{array}$ & $\begin{array}{l}\text { TATGGCTTCCCTCATTGCC } \\
\text { TATAGCTGTTGCTTCTGACG }\end{array}$ & $s u b A B$ & $\begin{array}{c}95^{\circ} \mathrm{C}, 2 \mathrm{~min}(1 \mathrm{ciclo}) ; 95^{\circ} \mathrm{C}, 1 \mathrm{~min}, 65^{\circ} \mathrm{C}, 2 \mathrm{~min}, \\
72^{\circ} \mathrm{C}, 1,5 \mathrm{~min}(10 \text { ciclos }) ; 95^{\circ} \mathrm{C}, 1 \mathrm{~min}, 60^{\circ} \mathrm{C} \\
2 \mathrm{~min}, 72{ }^{\circ} \mathrm{C}, 1,5 \mathrm{~min}(25 \text { ciclos })\end{array}$ & 0,5 & 556 & $\begin{array}{l}\text { Paton y } \\
\text { col., } 2004\end{array}$ \\
\hline $\begin{array}{l}\text { cdt-V F } \\
\text { cdt-V R }\end{array}$ & $\begin{array}{l}\text { TTCATTGTTCGCCTCCTG } \\
\text { TTTATAAGCTGGTATCCTG }\end{array}$ & $c d t-\mathrm{V}$ & Idem eae & 0,4 & 755 & $\begin{array}{l}\text { Cergole- } \\
\text { Novella y } \\
\text { col., } 2007\end{array}$ \\
\hline $\begin{array}{l}\text { hlyA1 } \\
\text { hlyA4 }\end{array}$ & $\begin{array}{l}\text { GGTGCAGCAGAAAAAGTTGTAG } \\
\text { TCTCGCCTGATAGTGTTTGGTA }\end{array}$ & $e h x A$ & 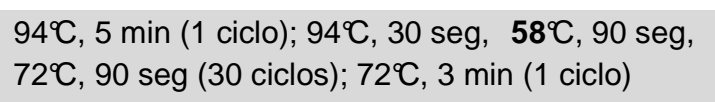 & 0,4 & 1.551 & $\begin{array}{l}\text { Schmidt y } \\
\text { col., } 1995\end{array}$ \\
\hline
\end{tabular}

Tabla 2. Secuencias de los cebadores y condiciones de ciclado para las PCR realizadas en este trabajo. Las diferentes temperaturas de pegado de los cebadores se encuentran resaltadas 


\subsection{1.- Aislamiento de ADN total}

Un mililitro de cada cultivo bacteriano crecido en CTS a $37^{\circ} \mathrm{C}$ durante $18 \mathrm{~h}$ se centrifugó durante 5 min a 12.000 rpm. El sedimento celular se resuspendió en 150 $\mu l$ de buffer tritón X-100 al 1\% en TE 1X [10 mM Tris-HCl (pH 8,0); 1 mM EDTA (pH 8,0)], se calentó a ebullición $\left(100^{\circ} \mathrm{C}\right)$ durante $15 \mathrm{~min}$, y se centrifugó a $12.000 \mathrm{rpm}$ por 5 min. El ADN contenido en el sobrenadante se separó y almacenó a $-20^{\circ} \mathrm{C}$ por un período máximo de 3 meses. Luego, $1 \mu \mathrm{l}$ de ese sobrenadante se utilizó como ADN templado en las reacciones de PCR.

\subsection{2.- Electroforesis y adquisición de imágenes}

Se agregaron $5 \mu \mathrm{l}$ de una solución de xilene cyanol 0,25\% y glicerol $30 \%$ en agua, a $25 \mu \mathrm{l}$ del ADN amplificado, sembrándose $10 \mu \mathrm{l}$ en un gel de agarosa (Sigma-Aldrich Co., St. Louis, MO, EE.UU.) al 2\% en buffer TAE 1X [40 mM tris-acético; 1mM EDTA (pH 8,0)] y adicionado con $0,5 \mu \mathrm{g}$ de bromuro de etidio/ml (Sigma-Aldrich Co., St. Louis, MO, EE.UU.). La electroforesis se realizó a $80 \mathrm{v} / \mathrm{cm}$ durante 50 min utilizando una fuente de poder PowerPac (Bio-Rad Laboratories, Hercules, CA, EE.UU.). Se utilizó el marcador de peso molecular Cienmarker (Biodynamics SRL, Argentina). Para documentar los geles se utilizó un transiluminador modelo 2000 (Bio-Rad Laboratories, Hercules, CA, EE.UU.) y el sistema Olympus C-5060, 5,1 MP (Olympus, Japón). El análisis de los geles se realizó con el programa DIGI Doc-lt versión 2.4.0 (UVP, Upland, CA, EE.UU.).

\section{5.- Ensayo de aglutinación de las fimbrias de tipo 1}

Una colonia aislada fue utilizada para inocular $5 \mathrm{ml}$ de caldo LB y cultivada durante $18 \mathrm{~h}$ a $37^{\circ} \mathrm{C}$. Luego, ese cultivo se repicó 2 veces consecutivas en el mismo medio y 
condiciones descriptas anteriormente. El ensayo de aglutinación se realizó sobre una placa de vidrio mezclando $20 \mu \mathrm{l}$ del cultivo bacteriano activado con igual volumen de una suspensión de levaduras en PBS 1X (10 mg/ml). La inhibición de la aglutinación, fue confirmada utilizando 3\% de D-manosa (MP Biomedicals Inc.) en la suspensión de levadura.

\subsection{1.- Determinación del estado de orientación de fimA}

La orientación del elemento invertible del promotor de fimA fue determinado utilizando una PCR-RFLP. Este método se basa en la orientación dependiente de la localización de un sitio único de restricción de $S n a B l$ que se encuentra en el fragmento de ADN amplificado. Para ello, se amplificó la región del promotor de fimA que permite determinar la orientación con los cebadores P3 y P4 (Tabla 2) generando un producto de $554 \mathrm{pb}$. Del producto de amplificación, $10 \mu \mathrm{l}$ se digirieron con $4 \mathrm{U}$ de la enzima SnaBI (Eco105I) (Fermentas). Los productos de digestión se resolvieron en un gel de agarosa (Sigma-Aldrich Co.) al 2\%.

\section{6.- Ensayo de expresión fenotípica de curli}

El ensayo de unión a rojo Congo se realizó según el protocolo descripto por Jonas y col. (2007). Brevemente, los cultivos bacterianos se crecieron en caldo LB con agitación, a $37^{\circ} \mathrm{C}$, durante $18 \mathrm{~h}$. Luego, se diluyeron 1:1 en agua destilada estéril y se sembraron gotas de $6 \mu \mathrm{l}$ aproximadamente en placas de rojo Congo. Las placas se incubaron a $30^{\circ} \mathrm{C}$ ó $37^{\circ} \mathrm{C}$ y se fotografiaron a las $24 \mathrm{~h}$ con una cámara Lumix DMC-TZ4 (Panasonic, Japón). 


\section{7.- Secuenciación nucleotídica}

La secuencia de ADN del gen IpfA de la cepa 187/06(22) fue determinada mediante el método de terminación di-deoxi de Sanger, utilizando un secuenciador automático Hitachi 3500 Genetic Analyzer (Applied Biosystems, Foster City, CA, EE.UU.), los cebadores IpfA-F, IpfA-R (Tabla 2) y las condiciones que se detallan a continuación. Se realizaron dos mezclas de reacción de secuenciación madres, una para la hebra codificante y otra para la hebra no codificante. La mezcla de reacción se realizó en un volumen final de $10 \mu \mathrm{l}$, conteniendo $7 \mathrm{ng} / \mu \mathrm{l}$ de ADN templado (producto de amplificación por PCR IpfA $\left.A_{0113}\right), 1 \mu \mathrm{M}$ de cada cebador, $1 \mu \mathrm{l}$ de la mezcla BigDye ${ }^{\mathrm{TM}}$ terminator versión 3.1 2,5X (Applied Biosystems, Foster City, CA, EE.UU.) y $2 \mu \mathrm{l}$ de buffer 5X (Applied Biosystems). Las condiciones de amplificación fueron 96ํㅡ por 1 min, seguido de 40 ciclos a $96^{\circ} \mathrm{C}$ por $10 \mathrm{seg}, 50^{\circ} \mathrm{C}$ por 5 seg y $60^{\circ} \mathrm{C}$ por $2 \mathrm{~min}$. La purificación de los productos de la reacción de secuenciación se realizó mediante precipitación con etanol. Las secuencias de ADN generadas se analizaron con el programa Bioedit versión 7.0.4.1 (Hall, 1999) y a través del Centro Nacional para la Información Biotecnológica (NCBI, por sus siglas en inglés National Center for Biotechnology Information) mediante la herramienta BLAST para acceder a la base de datos de secuencias genéticas.

\section{8.- Adherencia bacteriana in vitro}

\subsection{1.- Ensayo cualitativo}

Los ensayos cualitativos de adherencia bacteriana a células en cultivo in vitro, se realizaron siguiendo el protocolo descripto por Doughty y col. (2002), con algunas modificaciones. Se colocaron vidrios estériles de $12 \mathrm{~mm}$ de diámetro en placas de 24 
pocillos (Greiner bio-one $\mathrm{GmbH}$, Frickenhausen, Alemania ó Falcon ${ }^{\mathrm{TM}} \mathrm{BD}$, Franklin Lakes, NJ, EE.UU.), las cuales fueron posteriormente inoculadas con $10^{5}$ células HEp-2 por pocillo e incubadas a $37^{\circ} \mathrm{C}, 5 \% \mathrm{CO}_{2}$, hasta alcanzar aproximadamente un $80 \%$ de confluencia. Las monocapas semiconfluentes se lavaron 3 veces con buffer fosfato salino (PBS, por sus siglas en inglés phosphate-buffered saline) ( $\mathrm{NaCl} 8 \mathrm{~g}$; $\left.\mathrm{KCl} 0,2 \mathrm{~g} ; \mathrm{Na}_{2} \mathrm{HPO}_{4} 1,44 \mathrm{~g} ; \mathrm{KH}_{2} \mathrm{PO}_{4} 0,24 \mathrm{~g} ; \mathrm{pH} 7,4\right)$, se infectaron con ca. $10^{7}$ bacterias de un cultivo crecido por $18 \mathrm{~h}$ (MOI 100), y se incubaron 90 min a $37^{\circ} \mathrm{C}$, $5 \% \mathrm{CO}_{2}$ en presencia/ausencia de manosa al $1 \%$. Pasado el período de incubación, las células fueron lavadas 3 veces con PBS 1X para remover las bacterias no adheridas $\mathrm{o}$ adheridas inespecíficamente, y se incubaron por $4 \mathrm{~h}$ más en las mismas condiciones descriptas anteriormente. Transcurrido el segundo período de incubación, las células fueron lavadas 5 veces con PBS 1X y fijadas con metanol $70 \%$. Una vez que estuvieron secas, se tiñeron durante 15 min con una solución de Giemsa (Merck, Darmstadt, Alemania) 1:10 en agua destilada. Los vidrios se montaron sobre portaobjetos y se observaron utilizando un microscopio óptico Nikon Eclipse E200 (Nikon Corp., Tokyo, Japón). Las imagenes fueron capturadas con el sistema Nikon Coolpix 4500, 4.0 MP 4X zoom (Nikon Corp., Tokyo, Japón).

\subsection{2.- Ensayo cuantitativo}

Los ensayos cuantitativos de adherencia bacteriana in vitro se realizaron como se describió anteriormente con algunas modificaciones. Las monocapas celulares semiconfluentes se lavaron inicialmente 3 veces con PBS 1X. Aproximadamente $10^{5}$ células crecidas en placas de 24 pocillos (Falcon ${ }^{\mathrm{TM}} \mathrm{BD}$ ) fueron infectadas con ca. $10^{7}$ bacterias ( $\mathrm{MOI} 100$ ) e incubadas por $3 \mathrm{~h}$ a $37^{\circ} \mathrm{C}, 5 \% \mathrm{CO}_{2}$, en presencia/ausencia de manosa al $0,5 \%$. Pasado el período de incubación, las células fueron lavadas 2 
veces con PBS 1X y se lisaron con $200 \mu \mathrm{l}$ de una solución $0,1 \%$ de tritón X-100/PBS durante 30 min o hasta observarse desprendimiento total de la monocapa celular. Seguido a la lisis, $20 \mu \mathrm{l}$ del homogenato se resuspendieron en $180 \mu \mathrm{l}$ de caldo LB y se cuantificaron mediante diluciones seriadas en base 10, las cuales fueron sembradas en placas de LB-agar con su respectivo antibiótico, utilizando la técnica de la gota descripta por Chen y col. (2003). El porcentaje de bacterias adherentes se calculó como el número de UFC/ml de bacterias recuperadas, dividido el número de UFC/ml inicial, multiplicado por 100 (promedio \pm desviación estándar). Los ensayos se repitieron 2 veces por cuadruplicado cada vez.

\subsection{3.- Ensayo de competencia}

Los ensayos de competencia in vitro se realizaron como se describió anteriormente (ver ensayo cuantitativo de adherencia). Las células Caco-2 (clon CRL2102) se infectaron con $5 \times 10^{6}$ bacterias silvestre y mutante, respectivamente (número total de bacterias/pocillo $10^{7}$ ). El número de UFC/ml de las cepas silvestre y mutante fueron determinadas sembrando diluciones seriadas del homogenato en placas de LB-agar y LB-agar con el respectivo antibiótico para seleccionar la cepa mutante. El índice de competencia se calculó como el número de UFC/ml de bacterias mutantes recuperadas, dividido el número de UFC/ml de bacterias silvestres recuperadas; todo eso dividido el número de UFC/ml inicial de las bacterias mutantes, dividido el número de UFC/ml inicial de las bacterias silvestres.

\section{9.- Invasión bacteriana in vitro}

El ensayo cuantitativo de invasión bacteriana a células in vitro se realizó en las mismas condiciones descriptas anteriormente para el ensayo cuantitativo de 
adhrencia pero por duplicado, ya que luego de las $3 \mathrm{~h}$ de incubación inicial un grupo de células se lisó y cuantificó para dar el número total de bacterias adherentes, mientras que para obtener el número de bacterias intracelulares, un segundo grupo de pocillos infectados fueron lavados 2 veces con PBS $1 \mathrm{X}$ y se incubaron con 100 $\mu \mathrm{g} / \mathrm{ml}$ de $\mathrm{Gm}$ durante $2 \mathrm{~h}$. Seguida esta incubación, las células se lavaron 2 veces con PBS 1X y se lisaron con $200 \mu$ de una solución $0,1 \%$ de tritón X-100/PBS durante 30 min o hasta observarse desprendimiento total de la monocapa. Seguido a la lisis, $20 \mu \mathrm{l}$ del homogenato se resuspendieron en $180 \mu \mathrm{l}$ de caldo LB y se cuantificaron mediante diluciones seriadas en base 10. El total de bacterias intracelulares se expresó como el porcentaje del total de bacterias adherentes (promedio \pm desviación estándar). Los ensayos se realizaron 2 veces, por cuadruduplicado cada vez.

\subsection{0.- Análisis estadístico de los resultados de adherencia e invasión}

Para el análisis estadístico, las diferencias significativas en los ensayos de adherencia e invasión fueron calculadas mediante la prueba estadistica $t$ Student, utilizando el programa InStat versión 3.05 (GraphPad Software Inc., La Jolla, CA, EE.UU.).

\subsection{1.- Transformación de cepas bacterianas}

\subsection{1.- Aislamiento de ADN plasmídico}

La extracción de ADN plasmídico se realizó utilizando el kit Wizard® Plus SV Minipreps DNA Purification System (Promega Corp, Madison, WI, EE.UU.), a partir de $10 \mathrm{ml}$ de un cultivo bacteriano incubado durante $18 \mathrm{~h}$. Se utilizaron los reactivos y 
las condiciones descriptas por el fabricante. Brevemente, se centrifugaron $10 \mathrm{ml}$ del cultivo bacteriano. El sedimento celular se resuspendió en $250 \mu \mathrm{l}$ de la solución de resuspensión celular [50 mM Tris- $\mathrm{HCl}(\mathrm{pH}$ 7,5); 10 mM EDTA; $100 \mu \mathrm{g} / \mathrm{ml}$ RNasa A]. Luego, se adicionaron $250 \mu \mathrm{l}$ de la solución de lisis celular $(0,2 \mathrm{M} \mathrm{NaOH} ; 1 \%$ SDS) y se mezcló por inversión 4 veces. Se agregaron $10 \mu \mathrm{l}$ de la solución de proteasa alcalina y se mezcló nuevamente por inversión 4 veces, se incubó 5 min a temperatura ambiente y se neutralizó con $350 \mu \mathrm{l}$ de la solución de neutralización (4,09 M hidrocloluro de guanidinio; 0,759 M acetato de potasio; 2,12 M ácido acético glacial; pH 4,2) mezclándose nuevamente 4 veces por inversión. Seguido, se centrifugó por 10 min a velocidad máxima. El sobrenadante clarificado se transfirió a una columna y se centrifugó durante 1 min a máxima velocidad. Se realizaron 2 lavados, uno con $750 \mu \mathrm{l}$ y el otro con $250 \mu \mathrm{l}$ de la solución de lavado [60\% etanol; 60 $\mathrm{mM}$ acetato de potasio; 8,3 mM Tris-HCl (pH 7,5); 0,04 mM EDTA] y el ADN se eluyó con $100 \mu \mathrm{l}$ de agua libre de nucleasas. El ADN plasmídico se almacenó a $-20^{\circ} \mathrm{C}$ hasta su uso.

\subsection{2.- Preparación de bacterias electrocompetentes}

Una colonia de la cepa 187/06(22) fue inoculada en $5 \mathrm{ml}$ de caldo LB e incubada en agitación por $18 \mathrm{~h}$ a $37^{\circ} \mathrm{C}$. El cultivo crecido durante toda la noche se diluyó 1:200 en $25 \mathrm{ml}$ de caldo LB y se incubó en agitación a $37^{\circ} \mathrm{C}$ hasta alcanzar una densidad óptica de 0,6 a $600 \mathrm{~nm}\left(\mathrm{DO}_{600}\right)$. Una vez alcanzada la $\mathrm{DO}$, el cultivo se enfrió en hielo durante $20 \mathrm{~min}$ y luego se centrifugó a $4^{\circ} \mathrm{C}$ y $4.000 \mathrm{rpm}$ durante $6 \mathrm{~min}$. El sedimento celular se resuspendió en $1 \mathrm{ml}$ de agua destilada estéril fría. Se realizaron 2 lavados más con agua fría y 2 lavados con glicerol al 10\% frío. 
Una vez obtenidas las bacterias 187/06(22) transformadas con el plásmido pKM201, una colonia de la cepa 187/06(22) (pKM201) fue inoculada en $5 \mathrm{ml}$ de caldo LB suplementado con $100 \mu \mathrm{g} / \mathrm{ml}$ Amp e incubada en agitación por $18 \mathrm{~h}$ a 30․ El cultivo crecido durante toda la noche se diluyó 1:200 en $25 \mathrm{ml}$ de caldo LB suplementado con $100 \mu \mathrm{g} / \mathrm{ml}$ Amp, y se incubó en agitación a 30ㄷ hasta alcanzar una $\mathrm{DO}_{600}$ de 0,6 . Cuando el cultivo alcanzó aproximadamente $2 \times 10^{8}$ células, se enfrió en hielo durante 20 min y luego se centrifugó a 4ํ y 4.000 rpm durante 6 min. El sedimento celular se resuspendió en $1 \mathrm{ml}$ de agua destilada estéril fría. Se realizaron 2 lavados más con agua fría y 2 lavados con glicerol al 10\% frío. Las bacterias electrocompetentes se utilizaron el mismo día en el que fueron preparadas.

\subsection{3.- Electroporación}

Para la transformación, se mezclaron $50 \mu \mathrm{l}$ de bacterias electrocompetentes frescas, con 1, 2 ó $3 \mu \mathrm{l}$ del producto de PCR (0,5-1 $\mu \mathrm{g}$ ADN) o ADN plasmídico $(0,5 \mu \mathrm{g})$, en una cuveta de electroporación de 0,2 cm Gene Pulser ${ }^{\circledR} / E$. coli Pulser ${ }^{T M}$ (Bio-Rad Laboratories, Hercules, CA, EE.UU.). El equipo generador del pulso eléctrico GenePulser II (Bio-Rad Laboratories) fue calibrado en $25 \mu \mathrm{F}$ capacitancia; 2,5 kV; y $200 \Omega$ resistancia. Se aplicó un pulso, e inmediatamente se adicionó $1 \mathrm{ml}$ de caldo SOC. Luego de la electroporación, la suspensión bacteriana fue recuperada a $37^{\circ} \mathrm{C}$ ó $30^{\circ} \mathrm{C}$ (según correspondiera la cepa) por 2 h y se sembraron alícuotas apropiadas en medio selectivo (LB-agar suplementado con el antibiótico apropiado). Las placas se incubaron durante $24-48 \mathrm{~h}$. 


\subsection{2.- Construcción de una cepa mutante delecionada en $I p f A_{0113}$}

\subsection{1.- Purificación de fragmentos de ADN}

Los fragmentos de ADN se escindieron del gel de agarosa de bajo punto de fusión y se mezclaron con 3 volúmenes de buffer de solubilización L3 (isotiocianato de guanidinio). La agarosa se fundió a $50^{\circ} \mathrm{C}$ durante $15 \mathrm{~min}$. El proceso de purificación se realizó por centrifugación, utilizando columnas de afinidad PureLink ${ }^{T M}$ Quick Gel Extraction Kit (Invitrogen, Löhne, Alemania), los reactivos y las condiciones descriptas por su fabricante.

\subsection{2.- Construcción de la mutante IpfA}

Para generar una mutante delecionada en $I p f A_{0113}$ de la cepa $187 / 06(22)$, el gen $I p f A_{0113}$ fue reemplazado con un gen de resistencia a $\mathrm{Km}$ utilizando el sistema de recombinación lambda red (Datsenko y Wanner, 2000). Se sintetizaron cebadores largos para introducir la mutación siendo: IpfAKO-F (5'-ATA AGT CGA TGA TTC ATG GTA AAG GAT ATA TTA TAT CAA TGT GTA GGC TGG AGC TGC TTC-3') y IpfAKO-R (5'-CTG GCC AAA GCC AAC TGA ATA AAA AGG CCC TTG ATA AAT TCA TAT GAA TAT CCT CCT TAG-3'). Cada cebador incluye 20 pb de secuencia homóloga al plásmido utilizado como ADN templado, pKD4, y 40 pb de secuencia homóloga a las regiones flanqueantes del gen $I p f A_{0113}$. El gen de resistencia a $\mathrm{Km}$ se amplificó a partir del ADN plasmídico pKD4 por PCR, utilizando los cebadores descriptos anteriormente. La mezcla de reacción se realizó en un volumen final de $50 \mu \mathrm{l}$, conteniendo $2 \mu \mathrm{l}$ de ADN plasmídico como templado, $10 \mathrm{mM}$ Tris-HCl $(\mathrm{pH} 8,8)$; $50 \mathrm{mM} \mathrm{KCl} ; 0,8 \%$ Nonidet P40 (v/v); 0,75 mM MgCl 2 ; dNTP 0,1 mM cada uno (Invitrogen, Brasil); 0,05 $\mu \mathrm{M}$ de cada cebador; $1 \mathrm{U}$ de Taq ADN polimerasa recombinante (Fermentas) y 0,1 U de Pfx ADN polimerasa (Invitrogen, Brasil). Las 
condiciones de amplificación fueron $94^{\circ} \mathrm{C}$ por 5 min, seguido de 30 ciclos a $94^{\circ} \mathrm{C}$ por $1 \min , 60^{\circ} \mathrm{C}$ por $1 \min$ y $72^{\circ} \mathrm{C}$ por $2 \mathrm{~min}$. La extensión final fue a $72^{\circ} \mathrm{C}$ por $10 \mathrm{~min}$. El producto de PCR se corrió en un gel de agarosa al $2 \%$ y la banda de aproximadamente 1600 pb se escindió del gel y purificó como se describió anteriormente (ver purificación de fragmentos de ADN, sección 3.12.1). El producto de PCR purificado y previamente cuantificado utilizando el fluorómetro Qubit ${ }^{\mathrm{TM}}$ (Invitrogen, Carsldbad, CA, EE.UU.), se electroporó en la cepa 187/06(22), la cual fue previamente transformada con el plásmido pKM201. Las colonias resistentes a $\mathrm{Km}$ fueron chequeadas por PCR para observar el reemplazo del gen $\operatorname{lpf} A_{0113}$ por el marcador de resistencia a este antibiótico. Las mutantes $187 / 06(22) \Delta / p f A_{0113}$ fueron complementadas en trans gracias a la introducción del operrón completo de $\operatorname{lpf}_{\mathrm{O} 113}$ a través del plásmido pWSK:Ipf.

\subsection{3.- Extracción de proteínas por calor}

Las cepas bacterianas fueron crecidas en diferentes caldos: LB, LB sin hierro [dipiridil $200 \mu \mathrm{M}$ (Sigma-Aldrich Co., St. Louis, MO, EE.UU.)], DMEM; DMEM sin hierro; y temperaturas $\left(30^{\circ} \mathrm{C}\right.$ y $\left.37^{\circ} \mathrm{C}\right)$. Para la extracción de proteínas propiamente dicha, el cultivo bacteriano se estandarizó en una concentración de $4 \times 10^{9}$; se centrifugó a 3.000 xg por 10 min; se descartó el sobrenadante y el concentrado bacteriano se resuspendió en $160 \mu \mathrm{l}$ de PBS; el homogenato se calentó a $60^{\circ} \mathrm{C}$ durante 30 min y se centrifugó nuevamente a 3.000 xg por 10 min. Luego, el sobrenadante se transfirió a un nuevo tubo y se adicionaron $40 \mu$ de buffer de siembra 5X [60 mM Tris ( $\mathrm{pH}$ 6,8); 2\% SDS; 10\% glicerol; 5\% 2-mercaptoetanol; 0,01\% azul de bromofenol]. Las proteínas se calentaron a $70^{\circ} \mathrm{C}$ durante $10 \mathrm{~min}$ 
previo a ser colocadas en el gel para desnaturalizarlas y mantener reducidos los puentes disulfuro.

\subsection{4.- Electroforesis en gel de poliacrilamida desnaturalizante}

Las proteínas extraídas por calor $(15 \mu \mathrm{l})$, fueron separadas en geles de poliacrilamida desnaturalizantes. El gel separador fue preparado con poliacrilamida al $10 \%$, y el gel concentrador con poliacrilamida al $4 \%$. La corrida electroforética se realizó a $150 \mathrm{v} / \mathrm{cm}$ durante $60 \mathrm{~min}$ (Bio-Rad Laboratories). Los geles fueron teñidos mediante tinción rápida con una solución de azul brillante de Coomassie $(0,25 \%$ azul brillante de Coomassie; 40\% metanol; 10\% ácido acético glacial) durante $1 \mathrm{~min}$ a máxima potencia en microondas, y clarificados con una solución de desteñido ( $40 \%$ metanol, $10 \%$ ácido acético glacial) hasta observar el patrón electroforético de las proteínas. Se utilizó el marcador de peso molecular Prestained Protein Marker, Broad Range (New England BioLabs, MA, EE.UU.).

\subsection{5.- Secuenciación proteica}

Luego de realizar la corrida electroforética en gel de poliacrilamida desnaturalizante al $10 \%, 3$ bandas de aproximadamente $17 \mathrm{kDa}, 44 \mathrm{kDa}$ y $60 \mathrm{kDa}$, fueron identificadas mediante espectrometría de masa utilizando un analizador 4800 MALDI TOF/TOF Proteomics Analyzer (Applied Biosystems, Foster City, CA, EE.UU.). Para ello, se limpiaron 3 tubos plásticos con metanol, se escindieron las bandas proteicas de interés del gel de poliacrilamida utilizando una hoja de afeitar estéril para cada banda y se colocaron en $200 \mu \mathrm{l}$ de agua estéril calidad biología molecular en cada uno de los tubos plásticos, para luego ser entregados al servicio de espectrometría de masa (Mass Spectrometry Core Lab, UTMB, Galveston, TX, EEUU). 


\section{RESULTADOS}

\section{1.- Caracterización fenotípica y genotípica de las cepas}

Los serotipos, la fuente de aislamiento, los genotipos de la toxina Shiga y otros marcadores de virulencia de las cepas se muestran en la Tabla 3. Como criterio de inclusión elegido, todas las cepas fueron intimina-negativas y fermentaron el Dsorbitol (Anexo 1). Entre las cepas estudiadas, se identificaron 37 serotipos diferentes $(\mathrm{O}$ y $\mathrm{H})$, que comprendieron 27 serogrupos $\mathrm{O}$ y 18 antígenos $\mathrm{H}$. Sesenta y dos cepas fueron O no-tipificables (ONT) y 11 cepas O-rugoso (OR), 191 cepas fueron tipificables para el antígeno flagelar y 9 fueron no-móviles. Es importante señalar que 13 serotipos fueron comunes a cepas aisladas de ambos orígenes, sin embargo, algunos fueron especie específicos. Los serotipos comunes más prevalentes fueron: O113:H21 (12 cepas), O174:H21 (10 cepas), O130:H11 (9 cepas), O8:H19 (6 cepas), O15:H27 (4 cepas), O91:H21 (4 cepas) y O163:H19 (4 cepas).

Diferentes genotipos stx se observaron entre las cepas aisladas de ganado y las aisladas de humanos. Comparativamente, los genes $s t x_{2}$, st $x_{1} / s t x_{2}$ y $s t x_{1}$ fueron detectados en el $64 \% ; 26,8 \%$ y $9,2 \%$ de las cepas aisladas de ganado; y en el $83 \%$; $10,6 \%$ y el $6,4 \%$ de las cepas de origen humano, respectivamente.

Por PFGE fue posible subtipificar 186 aislamientos (14 se lisaron), generando 143 patrones moleculares diferentes (Anexo 1), con un 63,90\% de similitud, determinando asi una gran variedad de cepas. 
Origen

№ cepas positivas para los genes

\begin{tabular}{|c|c|c|c|c|c|c|c|c|c|c|c|}
\hline & & Igen & & & & IN= cepas & & s para & Ios genes & & \\
\hline & Bovino & Humano & Genotipo stx (№ cepas) & saa & ehxA & IpfA $\mathrm{O}_{0113}$ & iha & astA & subAB & $c d t-\mathrm{V}$ & $\operatorname{fimA}$ \\
\hline $\mathrm{O} 2: \mathrm{H} 25$ & 1 & & $s t x_{2 d}(1)$ & & & 1 & 1 & 1 & & & 1 \\
\hline O5:HNM & & $1^{\mathrm{a}}$ & $s t x_{1 a}(1)$ & 1 & 1 & 1 & 1 & & & & 1 \\
\hline O7:HNM & 2 & & $s t x_{1 a}(2)$ & & & 2 & & 2 & & & \\
\hline $\mathrm{O} 7: \mathrm{H} 21$ & 3 & & $s t x_{1 a} / \operatorname{stx}_{2 a}(1), s t x_{2 a}(1), s t x_{2 c}(v h-a)(1)$ & 2 & 2 & 3 & 3 & & 2 & 2 & 3 \\
\hline O8:H16 & 3 & $1^{\mathrm{b}}$ & $s t x_{1 a} / s t x_{2 a}(2), s t x_{2 a}(1), s t x_{1 a} / s t x_{2 d}(1)$ & 4 & 4 & 4 & 4 & & 1 & & 4 \\
\hline $\mathrm{O}: \mathrm{H} 19$ & 3 & $3^{\mathrm{b}}$ & $s t x_{2 \mathrm{~d}}(4), s t x_{1 \mathrm{a}} / s t x_{2 \mathrm{a}}(1), s t x_{2 \mathrm{~d} 2}(1)$ & 3 & 6 & 6 & 2 & & 1 & 1 & 6 \\
\hline $\mathrm{O} 15: \mathrm{H} 27$ & 2 & $2^{\mathrm{b}, \mathrm{c}}$ & $s t x_{2 \mathrm{~d} 2}(3), s t x_{1 \mathrm{c}} / s t x_{2 \mathrm{~d} 2}(1)$ & & & 4 & 4 & & & & 4 \\
\hline $\mathrm{O} 20: \mathrm{H} 19$ & & $1^{\mathrm{b}}$ & $s t x_{2 \mathrm{~d} 2}(1)$ & & & 1 & 1 & & & & 1 \\
\hline $\mathrm{O} 22: \mathrm{H} 8$ & 2 & & $s t x_{2 \mathrm{~d} 2}(2)$ & & & 2 & 2 & & & & 2 \\
\hline $\mathrm{O} 22: \mathrm{H} 16$ & 3 & & $s t x_{2 \mathrm{~d} 1}(1), s t x_{2 \mathrm{~d} 1} / s t x_{2 \mathrm{~d} 2}(1), s t x_{2 \mathrm{~b}-\mathrm{O} \times 3 \mathrm{a}}(1)$ & & & 3 & 3 & & & & 3 \\
\hline O39:H49 & 1 & & $s t x_{2 a}(1)$ & 1 & 1 & 1 & 1 & & 1 & & 1 \\
\hline O46:H38 & 2 & & $s t x_{1 a} / s t x_{2 a}(2)$ & 2 & 2 & 2 & 2 & & & & 2 \\
\hline O58:H40 & & $1^{\mathrm{c}}$ & $s t x_{1 a}(1)$ & & & 1 & & & & & 1 \\
\hline O59:H19 & & $4^{\mathrm{b}}$ & $s t x_{2 a}(4)$ & & & 4 & 4 & & & & 4 \\
\hline $\mathrm{O} 74: \mathrm{H} 12$ & 1 & & $s t x_{1 a}(1)$ & & & 1 & & 1 & & & \\
\hline O74:H28 & 1 & & $s t x_{2 \mathrm{~d} 2}(1)$ & 1 & 1 & 1 & 1 & & 1 & & 1 \\
\hline $\mathrm{O} 74: \mathrm{H} 42$ & 1 & & $s t x_{1 \mathrm{a}} / s t x_{2 \mathrm{~d}} / s t x_{2 \mathrm{~d} 2}(1)$ & 1 & 1 & 1 & 1 & & & & 1 \\
\hline O79:H19 & 2 & & $s t x_{1 \mathrm{a}} / s t x_{2 \mathrm{~d} 2}(2)$ & 2 & 2 & 2 & 2 & & 2 & & 2 \\
\hline O79:H28 & 1 & & $s t x_{2 \mathrm{~d} 2}(1)$ & 1 & 1 & 1 & 1 & & & & 1 \\
\hline
\end{tabular}


Origen

№ cepas positivas para los genes

\begin{tabular}{|c|c|c|c|c|c|c|c|c|c|c|c|}
\hline \multirow{2}{*}{ Serotipo } & \multicolumn{2}{|c|}{ Origen } & & \multicolumn{8}{|c|}{ № cepas positivas para los genes } \\
\hline & Bovino & Humano & Genotipo stx (№ cepas) & saa & ehxA & IpfA $\mathrm{A}_{0113}$ & iha & astA & subAB & $c d t-\mathrm{V}$ & fimA \\
\hline O82:H8 & 1 & & $s t x_{1 \mathrm{a}} / s t x_{2 \mathrm{a}}(1)$ & 1 & 1 & 1 & 1 & & & & 1 \\
\hline O91:H16 & 1 & & $s t x_{2 d}(1)$ & & 1 & 1 & & & & & 1 \\
\hline O91:H21 & 1 & $3^{\mathrm{a}, \mathrm{c}}$ & $s t x_{1 \mathrm{a}} / s t x_{2 \mathrm{~d}} / s t x_{2 \mathrm{~d} 2}(1), s t x_{2 \mathrm{a}}(1), s t x_{2 \mathrm{~d} 2}(1), s t x_{2 \mathrm{~d}} / s t x_{2 \mathrm{~d} 2}(1)$ & 4 & 4 & 4 & 4 & & 4 & 4 & 4 \\
\hline O113:H21 & 9 & $3^{\mathrm{b}, \mathrm{c}}$ & $s t x_{2 \mathrm{a}}(4), s t x_{2 \mathrm{~d}}(3), s t x_{1 \mathrm{a}} / s t x_{2 \mathrm{~d}} / s t x_{2 \mathrm{~d} 2}(2), s t x_{1 \mathrm{a}} / s t x_{2 \mathrm{~d} 2}(1) s t x_{2 \mathrm{~d}} / s t x_{2 \mathrm{~d} 2}(1), s t x_{2 \mathrm{~d} 2}(1)$ & 11 & 11 & 12 & 12 & 2 & 11 & 6 & 12 \\
\hline O116:H21 & 5 & & $s t x_{2 \mathrm{~d}}(2), s t x_{1 \mathrm{a}} / s t x_{2 \mathrm{~d}}(2), s t x_{1 \mathrm{a}} / s t x_{2 \mathrm{~d}} / s t x_{2 \mathrm{~d} 2}(1)$ & 5 & 5 & 5 & 5 & & 5 & 3 & 5 \\
\hline O124:H19 & 1 & & $s t x_{1 a} / s t x_{2 a}(1)$ & 1 & 1 & 1 & & & & & 1 \\
\hline O130:H11 & 7 & $2^{c, d}$ & $s t x_{1 \mathrm{a}} / s t x_{2 \mathrm{~d} 2}(4), s t x_{1 \mathrm{a}}(3) s t x_{1 \mathrm{a}} / \mathrm{stx} \mathrm{x}_{2 \mathrm{~d}}(1), s t x_{1 \mathrm{a}} / s t x_{2 \mathrm{a}}(1)$ & 8 & 8 & 9 & 8 & & 8 & & 9 \\
\hline O136:H12 & 7 & & $s t x_{1 a}(7)$ & & & 7 & & 7 & & & \\
\hline O141:H49 & 3 & & $s t x_{2 \mathrm{~d}}(2), s t x_{2 \mathrm{a}}(1)$ & 3 & 3 & 3 & 3 & & 1 & & 3 \\
\hline O143:HNM & & $1^{\mathrm{b}}$ & $s t x_{2 d}(1)$ & & & 1 & 1 & & & & 1 \\
\hline O163:H19 & 3 & $1^{\mathrm{c}}$ & $s t x_{2 a}(2), s t x_{2 d}(2)$ & 4 & 4 & 4 & 4 & & 4 & 4 & 4 \\
\hline $\mathrm{O} 171: \mathrm{H} 2$ & & $2^{c}$ & $s t x_{2 \mathrm{c}(\mathrm{vh}-\mathrm{a})}(1), s t x_{2 \mathrm{~d} 2}(1)$ & & & 2 & 2 & & & & 2 \\
\hline O174:H8 & & $1^{d}$ & 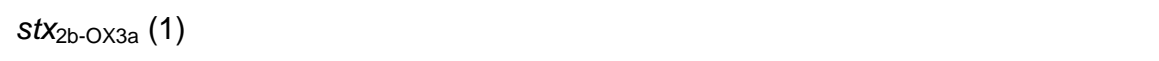 & & & 1 & & & & & 1 \\
\hline $\mathrm{O} 174: \mathrm{H} 21$ & 1 & $9^{b, c, d}$ & $s t x_{2 \mathrm{~d} 2}(10)$ & 1 & 1 & 10 & 10 & 4 & & & 10 \\
\hline $\mathrm{O} 174: \mathrm{H} 28$ & 1 & $2^{b}$ & $s t x_{2 \mathrm{~d}}(2), s t x_{1 \mathrm{a}} / s t x_{2 \mathrm{~d}}(1)$ & 3 & 3 & 3 & 3 & & 3 & 1 & 3 \\
\hline O174:HNM & & $1^{\mathrm{c}}$ & $s t x_{1 d} s t x_{2 b-0118}(1)$ & 1 & 1 & 1 & 1 & & & & 1 \\
\hline O178:H19 & 18 & & $s t x_{1 \mathrm{a}} / s t x_{2 \mathrm{a}}(7), s t x_{1 \mathrm{a}} / s t x_{2 \mathrm{~d}}(4), s t x_{2 \mathrm{c}(\mathrm{vh}-\mathrm{a})}(4), s t x_{2 \mathrm{~d} 2}(2), s t x_{2 \mathrm{~d}} / s t x_{2 \mathrm{~d} 2}(1)$ & 12 & 12 & 18 & 18 & & 5 & 3 & 18 \\
\hline O179:H8 & 3 & & $s t x_{2 d}(3)$ & 3 & 3 & 3 & 3 & & 3 & & 3 \\
\hline ONT:H2 & 21 & & $s t x_{2 \mathrm{c}(\mathrm{vh}-\mathrm{a})}(6), s t x_{2 \mathrm{~d} 2}(5), s t x_{2 \mathrm{~d} 1} / s t x_{2 \mathrm{~d} 2}(5), s t x_{2 \mathrm{~d}} / s t \mathrm{x}_{2 \mathrm{~d} 1}(2), s t x_{1 \mathrm{a}}(1), s t x_{2 \mathrm{~d} 1}(1), 2 \mathrm{NT}$ (1) & & & 21 & 21 & & & & 21 \\
\hline
\end{tabular}


Origen

№ cepas positivas para los genes

\begin{tabular}{|c|c|c|c|c|c|c|c|c|c|c|c|}
\hline & Bovino & Humano & Genotipo stx (№ cepas) & saa & ehxA & IpfA $_{0113}$ & iha & ast $A$ & subAB & $c d t-\mathrm{V}$ & fimA \\
\hline ONT:H4 & & $2^{\mathrm{b}}$ & $s t x_{2 \mathrm{a}}(2)$ & & & 1 & 2 & 1 & & & \\
\hline ONT:H7 & 8 & $1^{\mathrm{c}}$ & $s t x_{2 \mathrm{~d} 2}(7), s t x_{2 \mathrm{~d} 1}(1), s t x_{1 \mathrm{a}} / s t x_{2 \mathrm{a}}(1)$ & 1 & 1 & 9 & 7 & & 1 & & 9 \\
\hline ONT:H14 & 1 & & $s t x_{2 \mathrm{~d} 2}(1)$ & & & 1 & 1 & & & & 1 \\
\hline ONT:H19 & 7 & $1^{d}$ & $s t x_{2 \mathrm{~d}} / \mathrm{st} \mathrm{x}_{2 \mathrm{~d} 2}(5), s t x_{2 \mathrm{a}}(1), s t x_{2 \mathrm{~d} 2}(1), s t x_{2 \mathrm{c}(\mathrm{vh}-\mathrm{b})}(1)$ & 8 & 8 & 8 & 7 & & 8 & & 8 \\
\hline ONT:H21 & 6 & & $s t x_{1 \mathrm{a}} / s t x_{2 \mathrm{a}}(3), s t x_{2 \mathrm{~d}}(2), s t x_{2 \mathrm{~d} 2}(1)$ & 5 & 6 & 6 & 5 & & & & 6 \\
\hline ONT:H25 & 1 & & $s t x_{2 a}(1)$ & 1 & 1 & 1 & 1 & & 1 & 1 & 1 \\
\hline ONT:H28 & 2 & & $s t x_{2 d}(2)$ & & 2 & 2 & & 1 & & & 2 \\
\hline ONT:H46 & 6 & $1^{d}$ & $s t x_{2 \mathrm{~d}}(5), s t x_{2 \mathrm{~d} 2}(1), s t x_{2 \mathrm{~d}} / s t x_{2 \mathrm{~d} 2}(1)$ & 7 & 7 & 7 & 6 & & 7 & 1 & 7 \\
\hline ONT:H49 & & $1^{a}$ & $s t x_{1 a} / s t x_{2 d}(1)$ & 1 & 1 & 1 & 1 & & 1 & & 1 \\
\hline ONT:HNM & 1 & $3^{\mathrm{b}, \mathrm{c}}$ & $s t x_{2 a}(3), s t x_{1 a}(1)$ & & & 4 & 3 & 1 & & & 3 \\
\hline OR:H2 & 10 & & $s t x_{2 c(v h-a)}(5), s t x_{2 \mathrm{~d} 1}(1), s t x_{2 \mathrm{~d} 2}(1), s t x_{1 \mathrm{a}} / s t x_{2 \mathrm{a}}(1), s t x_{2 \mathrm{~d} 1} / s t x_{2 \mathrm{~d} 2}(1), 2 \mathrm{NT}(1)$ & 1 & 1 & 10 & 9 & & & & 10 \\
\hline OR:H19 & 1 & & $s t x_{1 a} / s t x_{2 a}(1)$ & 1 & 1 & 1 & 1 & & & & 1 \\
\hline Total & 153 & 47 & & 100 & 107 & 199 & 172 & 20 & 70 & 26 & 187 \\
\hline (\% cepas) & $(76,5)$ & $(23,5)$ & & $(50,0)$ & $(53,5)$ & $(99,5)$ & $(86,0)$ & $(10,0)$ & $(35,0)$ & $(13,0)$ & $(93,5)$ \\
\hline
\end{tabular}

Tabla 3. Serotipos, origen, genotipo de toxina Shiga y otros marcadores de virulencia de las cepas E. coli estudiadas.

${ }^{a}$ DS. ${ }^{b}$ SUH. ${ }^{c} D$. ${ }^{d}$ Asintomáticos. OR:O-rugoso, HNM:no móvil, NT:no tipificable.

Los genotipos de toxina Shiga se encuentran denominados de acuerdo al consenso de nomenclatura del VTEC 2009.

$s t x_{1 a}\left(\right.$ antiguamente denominada $\left.s t x_{10 n l y}\right) ; s t x_{2 a}$ (antiguamente denominada $\left.s t x_{2 o n l y}\right) ; s t x_{2 c(v h-a)}$ (antiguamente denominada $\left.s t x_{2 v h-a}\right) ; s t x_{2 c(v h-b)}($ antiguamente denominada $\left.s t x_{2 \mathrm{vh}-\mathrm{b}}\right) ; s t x_{2 \mathrm{~b}-0118}$ (antiguamente denominada $\left.s t x_{2 \mathrm{~d}-\mathrm{ount}}\right)$; $s t x_{2 \mathrm{~b}-\mathrm{ox} 3 \mathrm{a}}\left(\right.$ antiguamente denominada $\left.s t x_{2 \mathrm{~d}-0 \mathrm{x}_{3 \mathrm{a}}}\right)$; $s t x_{2 \mathrm{~d}}\left(s t x_{2 \mathrm{only}}\right.$ activable); $s t x_{2 \mathrm{~d} 1}\left(s t x_{2 \mathrm{vh}-\mathrm{a}}\right.$ activable); $s t x_{2 \mathrm{~d} 2}\left(s t x_{2 \mathrm{vh}-\mathrm{b}}\right.$ activable). 


\section{2.- Marcadores de virulencia}

La distribución de los genes que codifican para las adhesinas putativas y factores de virulencia adicionales, se muestra en la Figura 6. Los genes más comunes, entre todas las cepas estudiadas, fueron los codificados por $I p f A_{0113}(199 / 200 ; 99,5 \%)$ y fimA $(187 / 200 ; 93,5 \%)$. Cabe destacar que la única cepa $I p f A_{0113}$-negativa fue aislada de un caso de SUH perteneciente al serotipo ONT:H4. La región promotora del gen fimA estuvo presente en 142/153 (92,8\%) cepas bovinas y en $45 / 47(95,7 \%)$ cepas humanas; mientras que el gen iha estuvo presente en 130/153 (85\%) y en $42 / 47$ (89,4\%), respectivamente (Figura 6). De las 187 cepas fimA-positivas, 175 (93,6\%) expresaron la fimbria de tipo 1 por el ensayo de aglutinación con levaduras, mientras que 12 no la expresaron a pesar de los sucesivos pasajes en caldo LB para estimular la expresión. También hubo una asocoación entre el fenotipo y los productos obtenidos mediante PCR-RFLP para determinar el estado de orientación de fimA, ya que las cepas que daban aglutinación positiva poseían el patrón de restricción característico de fimA encendido, dando bandas de 442 pb y 112 pb. Las cepas fimA-negativas, aisladas de ambos orígenes, pertenecieron a los serotipos 0136:H12 (7 cepas), O7:HNM (2 cepas), O74:H12 (1 cepa), y tres cepas fueron no tipificables. Las cepas iha-negativas pertenecieron a los serotipos 0136:H12 (7 cepas), O8:H19 (4 cepas), O7:HNM (2 cepas), O58:H40, O74:H12, O91:H16, O124:H19, O130:H11, O174:H8 (una cepa de cada uno), y nueve cepas fueron no tipificables. Curiosamente, todas las cepas fimA-negativas también fueron ihanegativas, a excepción de las dos cepas del serotipo ONT: H4 (Tabla 3). 


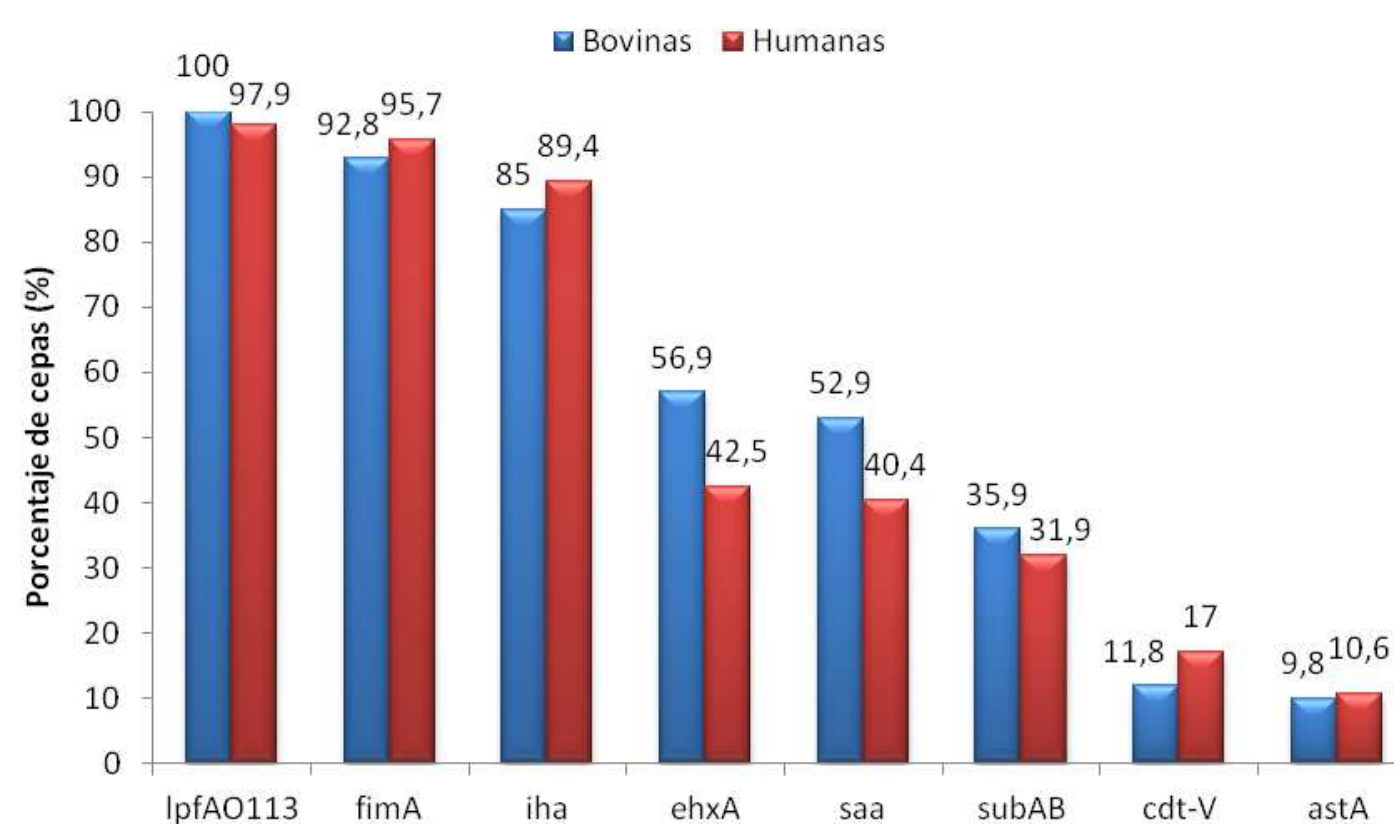

Figura 6. Distribución de los marcadores genéticos de virulencia en las cepas STEC de origen bovino y humano. Las cepas bovinas están respresentadas en color azul y las cepas humanas en color rojo.

El gen ehxA estuvo presente en 107 (53,5\%) de las 200 cepas estudiadas, independientemente del origen. De las 107 cepas ehxA-positivas, 100 fueron también saa-positivas. El gen ehxA estuvo presente en $87 / 153(56,9 \%)$ cepas de ganado y en $20 / 47(42,5 \%)$ cepas STEC humanas. Además, el gen saa fue detectado en $81 / 153(52,9 \%)$ y $19 / 47(40,4 \%)$, respectivamente (Figura 6$)$. Ninguna cepa ehxA-negativa fue positiva para el gen saa. Todas las cepas fueron toxB y efa1-negativas. Este hallazgo es coincidente con estudios previos que asocian con mayor frecuencia estos genes a cepas intimina-positivas (Toma y col., 2004; Cergole-Novella y col., 2007).

La presencia de secuencias génicas relacionadas con subAB, cdt- $\mathrm{V}$ y ast $A$, se confirmó en 70/200 (35\%), 26/200 (13\%) y 20/200 (10\%) de las cepas, respectivamente. No se observó diferencia estadísticamente significativa en la 
frecuencia de subAB, cdt- $\mathrm{V}$ y ast $A$, entre las cepas aisladas de ganado bovino y las cepas humanas. El gen subAB estuvo presente en $55 / 153$ (35,9\%) cepas bovinas y en $15 / 47$ (31,9\%) cepas humanas; cdt-V en $18 / 153(11,8 \%)$ y en $8 / 47(17 \%)$; y ast $A$ en $15 / 153(9,8 \%)$ y en $5 / 47(10,6 \%)$, respectivamente (Figura 6$)$. Las cepas subABpositivas pertenecieron a varios serotipos, pero los más frecuentes fueron O113:H21 (10 cepas), O130:H11 (6 cepas), O116:H21 (5 cepas), O178:H19 (5 cepas) y O91:H21 (4 cepas). Los serotipos más frecuentes de las cepas cdt-V-positivas fueron O113:H21 (6 cepas), O91:H21 (4 cepas) y O163:H19 (4 cepas). Todas las cepas cdt-V-positivas fueron subAB-positivas, pero no todas las cepas subABpositivas fueron cdt-V-positivas. Las cepas astA-positivas pertenecieron a los serotipos O136:H12 (7 cepas), O174:H21 (4 cepas), O7:HNM (2 cepas), O113:H21 (2 cepas), O2:H25 (1 cepa), O74:H12 (1 cepa), y 3 cepas fueron no tipificables (Tabla 3).

\subsection{1.- Variantes de IpfA}

Una vez finalizada la caracterización genotípica de los marcadores de virulencia de las 200 cepas estudiadas, Torres y col. (2009) identificaron algunos polimorfismos en la secuencia nucleotídica de los genes IpfA1 y IpfA2, lo que le permitió clasificar la subunidad principal en distintas variantes.

Utilizando la clasificación experimental descripta por Torres y col. (2009), se encontró que de todas las cepas IpfA $A_{0113}$-positivas, la variante $\operatorname{lpfA2-1}$ fue la más prevalente. Como se muestra en el Anexo 1 la variante IpfA2-1 estuvo presente en 198/199 cepas IpfA $A_{0113}$-positivas $(99,5 \%)$, mientras que la variante IpfA2-3 estuvo presente en una cepa. La frecuencia de IpfA1-2 fue del 46\% (92/200) y aparentemente este gen se haya asociado a IpfA2-1, ya que siempre se los encontró 
juntos. En ninguna de las cepas estudiadas se encontraron las variantes IpfA1-1, IpfA1-3, IpfA1-4, IpfA1-5, ni IpfA2-2.

La única cepa STEC IpfA-negativa identificada en este estudio fue aislada de un caso de SUH, perteneció al serotipo ONT:H4, y el único factor de adherencia detectado fue el gen iha.

No se pudo establecer ninguna asociación estadísticamente significativa entre la presencia de alguna variante particular de IpfA y la severidad de la enfermedad. Sin embargo, se observó que la mayoría de los serotipos mantienen la misma combinación de variantes de Ipf, independientemente del origen de las cepas. Tales resultados se ven reflejados por ejemplo en el serogrupo O22, en el que se encuentran dos cepas del serotipo O22:H8 que portan las variantes IpfA1-2 y IpfA21, mientras que las tres cepas del serotipo O22:H16 sólo poseen la variante IpfA2-1. Resultados similares pueden observarse en el serogrupo O174, donde todas las cepas 0174:H21 poseen las variantes IpfA1-2 y IpfA2-1, mientras que los otros serotipos de O174 (O174:H8, O174:H28 y O174:NM) sólo portan el gen IpfA2-1 (Anexo 1).

\section{3.- Comparación del perfil de virulencia de las cepas estudiadas}

Se observaron distintos perfiles de virulencia entre las cepas STEC LEE-negativas analizadas, encontrándose diferencias entre las cepas bovinas y las cepas humanas (Tabla 4). Se identificaron once perfiles de virulencia diferentes entre las 153 cepas bovinas, siendo la combinación de $I p f A_{0113} /$ ihal fimA la más frecuente $(49 / 153$, $32 \%)$, seguido por IpfA $A_{0113} /$ ihal saal ehxA/ subAB/ fimA $(32 / 153,21 \%)$ y $\mid p f A_{0113} /$ ihal saal ehxA/ fimA (29/153, 19\%). Entre las 47 cepas STEC LEE-negativas de 
origen humano, también fueron reconocidos 11 perfiles de virulencia diferentes. El perfil identificado con mayor frecuencia fue idéntico al más prevalente detectado entre las cepas bovinas $\operatorname{Ipf} A_{0113} /$ ihal $\operatorname{fim} A(19 / 47 ; 40,4 \%)$. El segundo perfil más frecuente observado fue $I p f A_{0113} /$ iha/ saal ehxA/ subAB/ cdt-V/fimA, encontrándose en ocho cepas de las $47(17,2 \%)$.

\begin{tabular}{|c|c|c|c|}
\hline \multirow{2}{*}{ Perfil de virulencia } & \multicolumn{2}{|c|}{ № de cepas (\%) } & \multirow{2}{*}{ Valor $p$} \\
\hline & Humanas & Bovinas & \\
\hline IpfA $A_{0113} /$ ihal fimA & $19(40,4)$ & $49(32)$ & NS \\
\hline IpfA $A_{0113} /$ ihal saa/ ehxA/ subA/ fimA & $6(12,8)$ & $32(21)$ & NS \\
\hline IpfA $\mathrm{O}_{113} /$ ihal saal ehxA/ fimA & $3(6,4)$ & $29(19)$ & $<0.05$ \\
\hline IpfA $A_{0113} /$ ihal saal ehxA/ subA/ cdt-V/fimA & $8(17,2)$ & $17(11)$ & NS \\
\hline IpfA $\mathrm{O}_{113} /$ ast $A$ & $0(0)$ & $11(7,2)$ & $<0.05$ \\
\hline IpfA $A_{0113} /$ ehxA/ fimA & $1(2,1)$ & $5(3,5)$ & NS \\
\hline IpfA $A_{0113} /$ fimA & $2(4,3)$ & $4(2,6)$ & NS \\
\hline IpfA $A_{0113} /$ ihal astA/ fimA & $4(8,5)$ & $2(1,3)$ & $<0.05$ \\
\hline IpfA $A_{0113} /$ saal ehxA/ fimA & $1(2,1)$ & $2(1,3)$ & NS \\
\hline IpfA $A_{113} /$ ihal saa/ ehxA/ subA/ cdt-V/ astA/ fimA & $0(0)$ & $1(0,6)$ & NS \\
\hline IpfA $A_{0113} /$ ehxA/ astA/ fimA & $0(0)$ & $1(0,6)$ & NS \\
\hline IpfA $A_{0113} /$ ihal astA & $1(2,1)$ & $0(0)$ & NS \\
\hline IpfA $A_{0113} /$ saal ehxA/ subA/ fimA & $1(2,1)$ & $0(0)$ & NS \\
\hline iha & $1(2,1)$ & $0(0)$ & NS \\
\hline Total & 47 & 153 & \\
\hline
\end{tabular}

Tabla 4. Comparación de los perfiles de virulencia identificados en cepas STEC LEE-negativas aisladas de bovinos y casos de infección humana. NS, no significativo $(p>0,05)$.

La asociación entre el perfil de virulencia, la infección humana, y los serotipos de STEC se muestra en la Tabla 5. De los once perfiles identificados en las cepas 
humanas, nueve se asociaron a SUH. El perfil más frecuente, IpfA $A_{0113} /$ iha/ fimA, fue identificado en cepas de diferentes serotipos aislados de nueve casos de SUH, ocho casos de $\mathrm{D}$ y dos contactos asintomáticos. De los casos de SUH, dos pacientes fallecieron durante la fase aguda de la enfermedad y las cepas pertenecieron a los serotipos O143:HNM y ONT:HNM. Además, otros dos pacientes con SUH fallecieron y las cepas aisladas portaron los genes IpfA $A_{0113} /$ iha/ saa/ ehxA/ subAB/ cdt-V/ fimA y pertenecieron a los serotipos O113:H21 y O174:H28. 


\begin{tabular}{|c|c|c|}
\hline Perfil & $\begin{array}{l}\text { Infección humanana } \\
\text { (№ de casos ) }\end{array}$ & Serotipo (№ de cepas) \\
\hline \multirow[t]{3}{*}{ IpfA $A_{0113} /$ ihal fimA } & SUH (9) & O15:H27 (1), O20:H19 (1), O59:H19 (4), O143:NM (1)*, ONT:NM (2)* \\
\hline & $\mathrm{D}(8)$ & O15:H27 (1), O171:H2 (2), O174:H21 (3), ONT:H7 (1), ONT:NM (1) \\
\hline & $A(2)$ & O174:H21 (2) \\
\hline \multirow[t]{4}{*}{ IpfA $A_{1113} /$ ihal saa/ ehxA/ subA/fimA } & SUH (1) & O174:H28 (1) \\
\hline & $\mathrm{D}(2)$ & O113:H21 (1), O130:H11 (1) \\
\hline & DS (1) & ONT:H49 (1) \\
\hline & $A(2)$ & ONT:H46 (1), O130:H11 (1) \\
\hline \multirow[t]{3}{*}{ IpfA $A_{0113} /$ ihal saal ehxA/ fimA } & SUH (1) & $\mathrm{O} 8: \mathrm{H} 16(1)$ \\
\hline & $\mathrm{D}(1)$ & O174:NM (1) \\
\hline & $A(1)$ & O5:NM (1) \\
\hline \multirow[t]{3}{*}{ IpfA $A_{113} /$ iha/ saa/ ehxA/ subA/ cdt-V/ fimA } & SUH (3) & $\mathrm{O} 113: \mathrm{H} 21(2)^{*}, \mathrm{O} 174: \mathrm{H} 28(1)^{*}$ \\
\hline & $\mathrm{D}(4)$ & O91:H21 (2), O8:H19 (1), O163:H19 (1) \\
\hline & DS (1) & O91:H21 (1) \\
\hline IpfA $A_{0113} /$ ehxA/fimA & SUH (1) & $\mathrm{O} 8: \mathrm{H} 19(1)$ \\
\hline IpfA $A_{0113} /$ fimA & $\mathrm{D}(1), \mathrm{A}(1)$ & O58:H40 (1), O174:H8 (1) \\
\hline IpfA $A_{0113} /$ ihal astA/ fimA & SUH (1), D (1), A (2) & O174:H21 (4) \\
\hline IpfA $A_{0113} /$ saal ehxA/ fimA & SUH (1) & $\mathrm{O} 8: \mathrm{H} 19(1)$ \\
\hline IpfA $A_{0113} /$ ihal ast $A$ & SUH (1) & ONT:H4 (1) \\
\hline Ipf $A_{0113} /$ saal ehxA/ subA/ fimA & $A(1)$ & ONT:H19 (1) \\
\hline iha & SUH (1) & ONT:H4 (1) \\
\hline
\end{tabular}

Tabla 5. Asociación entre perfil de virulencia, infección humana y serotipos de STEC. *Pacientes fallecidos. 


\section{4.- Adherencia bacteriana in vitro}

Las cepas STEC que carecen de la isla de patogenicidad LEE son comunmente aisladas de reservorio animal, casos esporádicos de diarrea, y recientemente fueron asociadas a brotes de enfermedades transmitidas por alimentos. Sin embargo, poco se conoce sobre los mecanismos por los cuales este grupo de patógenos se adhiere y coloniza el intestino causando enfermedad.

\subsection{1.- Ensayos cualitativos de adherencia in vitro}

Una vez determinados los factores de virulencia de las 200 cepas estudiadas, se eligieron aquellas que presentaban perfiles de adhesinas únicos y se compararon los fenotipos de adherencia a través de ensayos in vitro con células HEp-2. Del total de cepas STEC LEE-negativas, sólo se encontraron cepas IpfA $_{0113}$-positivas (variante IpfA2-1) de origen bovino y una cepa iha-positiva de origen humano (SUH). A modo comparativo, también se seleccionó una cepa de origen humano (SUH) positiva para los genes iha y $\operatorname{lpf} A_{0113}$ (variante $\left.I p f A 2-3\right)$. Las cepas $I p f A_{0113}$-positivas pertenecieron a los serotipos O136:H12, O7:H[12], y ONT:HNM; la cepa iha-positiva al serotipo ONT:H4; y la cepa combinada al serotipo O143:H[4] (Tabla 6).

\begin{tabular}{lllll}
\hline \multirow{2}{*}{ Origen } & Serotipo & stx & Positivo & Negativo \\
\cline { 5 - 5 } Bovino & O136:H12 & stx & IpfA2-1/astA & saa, efa1, toxB, subAB, cdt-V, fimA \\
Bovino & O7:H[12] & stx 1 & IpfA2-1/astA & saa, efa1, toxB, subAB, cdt-V, fimA \\
Bovino & ONT:HNM & stx 1 & IpfA2-1/astA & saa, efa1, toxB, subAB, cdt-V, fimA \\
Humano & ONT:H4 & stx 1 & iha & saa, efa1, toxB, astA, IpfA1, IpfA2, subAB, cdt-V, fimA \\
Humano & O143:H[4] & stx & iha/lpfA2-3 & saa, efa1, toxB, astA, subAB, cdt-V \\
\hline
\end{tabular}

Tabla 6. Cepas seleccionadas para el estudio de adherencia bacteriana in vitro. Los genes $I p f A_{0113}$ se encuentran identificados con sus respectivas variantes. 
Como puede observarse en la Figura 7, las cepas $I p f A_{0113}$-positivas $\mathrm{O} 136: \mathrm{H} 12$ y $\mathrm{O} 7: \mathrm{H}[12]$ mostraron un patrón de adherencia parcialmente localizado sobre la superficie celular denominado LAL por sus siglas en inglés localized adherence like, mientras que la cepa ONT:HNM mostró una adherencia difusa. La cepa iha-positiva mostró un patrón de adherencia típico de las cepas EAEC, pudiéndose observar la disposición en empalizada de las bacterias alrededor de las células. En cambio, la cepa combinada $(\mathrm{O} 143: \mathrm{H}[4])$ mostró un patrón de adherencia difuso sobre la superficie celular.
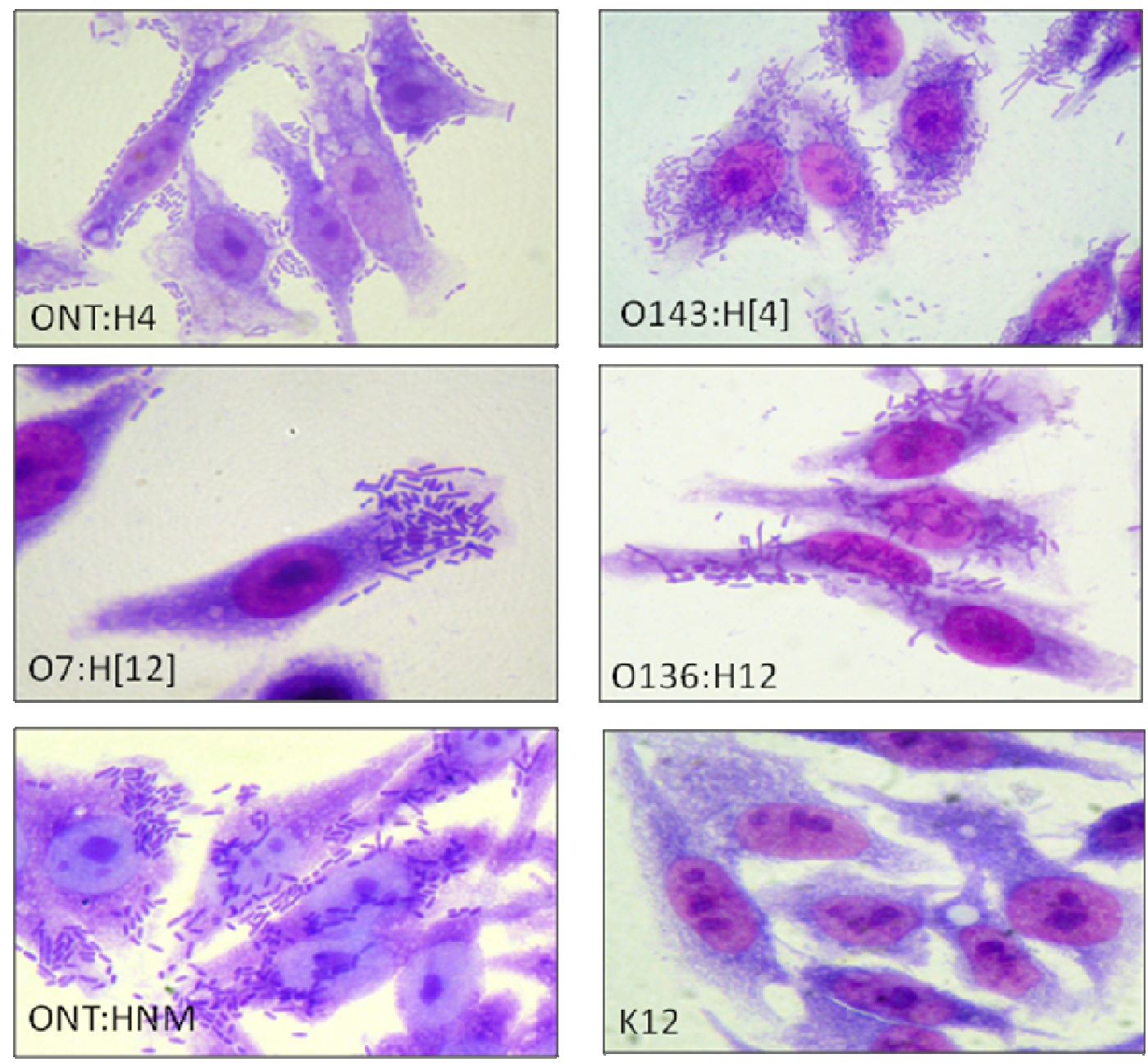

Figura 7. Ensayo cualitativo de adherencia bacteriana in vitro a células HEp-2. Las cepas O7:H[12], O136:H12, ONT:HNM son IpfA $A_{0113}$-positivas (variante IpfA2-1); la cepa

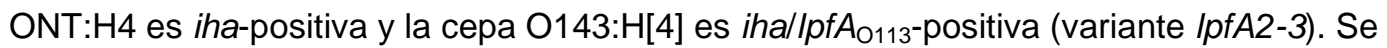
utilizó la cepa K12 como control negativo. 


\section{5.- Secuenciación del gen $I p f A_{0113}$}

Luego se secuenció el gen IpfA $A_{0113}$ de la cepa 187/06(22) (O136:H12), observándose $98 \%$ de similitud con el gen $I p f A_{0113}$ de la cepa EH41 (O113:H21) descripta en el trabajado de Doughty y col. (2002) (Figura 8). Por lo tanto se utilizaron los mismos criterios y secuencias de los cebadores descriptos en el trabajo mencionado anteriormente para construir la cepa mutada en IpfA. La mayoría de las diferencias nucleotídicas se produjeron al comienzo y finalización de la secuencia, pudiendo especular que se deben a errores en el proceso de secuenciación, ya que además coinciden con la secuencia de los cebadores.

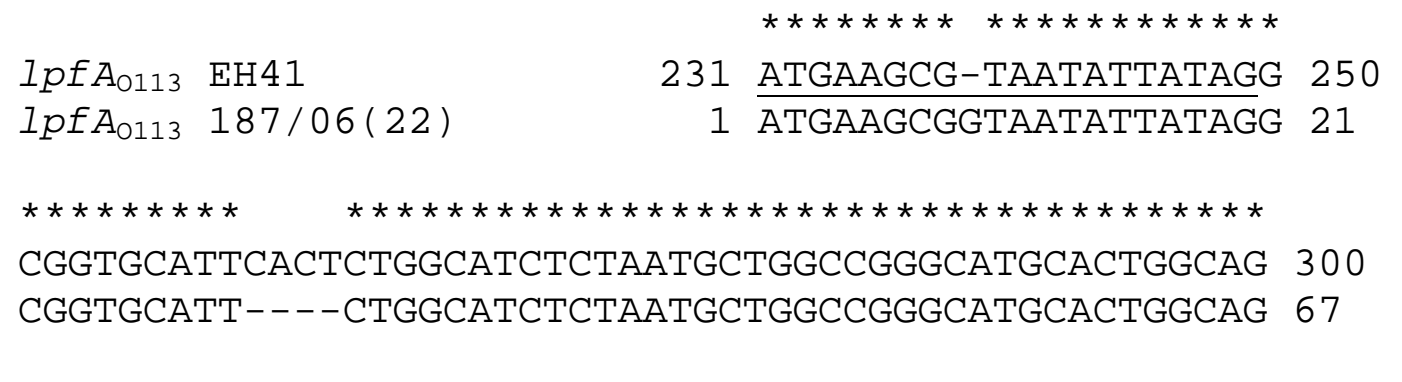

AAGATGGTGTTGTTCACTTCGTCGGTGAAATTGTCGACACTACTTGTGAA 350 AAGATGgtGtTGtTCACTTCGTCGGTGAAATtGTCGACACTACTTGTGAA 117

GTTACCTCCGATACAGCCGATCAAATTGTCCCACTGGGTAAAGTCAGTAA 400 GTTACCTCCGATACAGCCGATCAAATTGTCCCACTGGGTAAAGTCAGTAA 167

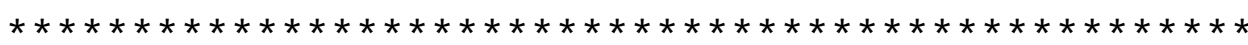

AAATGCATTTTCAGGTGTAGGTAGTCTGGCGTCGCCACAGAAGTTCAGTA 450 AAATGCATTTTCAGGTGTAGGTAGTCTGGCGTCGCCACAGAAGTTCAGTA 217

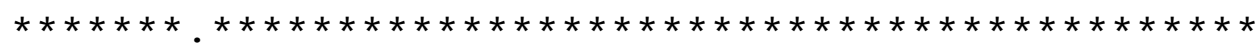

TTAAGCTCGAAAATTGCCCGGCAACGTACACTCAAGCAGCCGTTCGTTTT 500 TTAAGCTTGAAAATTGCCCGGCAACGTACACTCAAGCAGCCGTTCGTTTT 267

GATGGTACAGAAGCGCCTGGCGGCGACGGCGACCTGAAAGTGGGTACGCC 550

GCTTACAGCAGGCAACCCTGGTGATTTTACCGGTACAGGACAAGCGATTG 600 GCTTACAGCAGGCAACCCTGGTGATTTTACCGGTACAGGACAAGCGATTG 367 
CGGCAACCGGCGTTGGTATTCGTATTTTTAACCAGTCCGATAATTCGCAG 650

CGGCAACCGGCGTTGGTATTCGTATTTTTAACCAGTCCGATAATTCGCAG 417

$* * * * * * * * * * * * * * * * * * * * * * * * * * * * * * * * * * * * * * * * * * * * * * * * * * *$

GTTAAACTTTATAACGACTCTGCTTATACCGCTATCGATGCTGAAGGCAA 700

GTTAAACTTTATAACGACTCTGCTTATACCGCTATCGATGCTGAAGGCAA 467

GGCTGAAATGAAGTTTATTGCACGCTATGTGGCAACCAATGCGACCGTAA 750

GGCTGAAATGAAGTTTATTGCACGCTATGTGGCAACCAATGCGACCGTAA 517

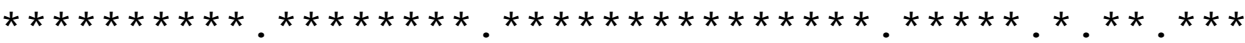

CGGCTGGTACAGCGAACGCTGATTCACAATTTACTGTCGAATATAAGAAA 800

CGGCTGGTACGGCGAACGCGGATTCACAATTTACTATCGAAAAAAAAAAA 567

$\star \star \star$

TAA 803

TAA 570

Figura 8. Alineamiento nucleotídico de $I p f A_{0113}$ de la cepa EH41 (№ accceso al banco de genes AY057066) y la cepa 187/06(22) secuenciada en el presente trabajo. El alineamiento se realizó con el programa ClustalX2 (versión 2.0.12), y el número de nucleótido se encuentra señalado a la derecha. Los gaps se indican con una línea, y los nucleótidos conservados con un asterisco. Los nucleótidos variables se encuentran resaltados y están marcados con un punto. Los cebadores utilizados para la secuenciación se encuentran subrayados.

\subsection{1.- Construcción de la cepa mutada en $I p f A_{0113}$}

Utilizando el sistema de recombinación lambda red y el protocolo descripto en Materiales y Métodos (ver sección 3.12) se construyó una cepa mutada para el gen $I p f A_{0113}$. Las cepas recombinantes capaces de crecer en LBagar suplementado con $50 \mathrm{\mu g} / \mathrm{ml}$ de $\mathrm{Km}$ y sensibles a Amp, fueron corroboradas mediante PCR, utilizando los cebadores IpfA-F y IpfA-R, para observar la pérdida del gen Ipf $A_{0113}$, ya que los cebadores utilizados para generar la mutante tenían $40 \mathrm{pb}$ de secuencia homóloga a las regiones flanqueantes del gen $I p f A_{0113}$, obteniendo de esa manera una cepa delecionada en $I p f A_{0113}$ (Figura 9). 


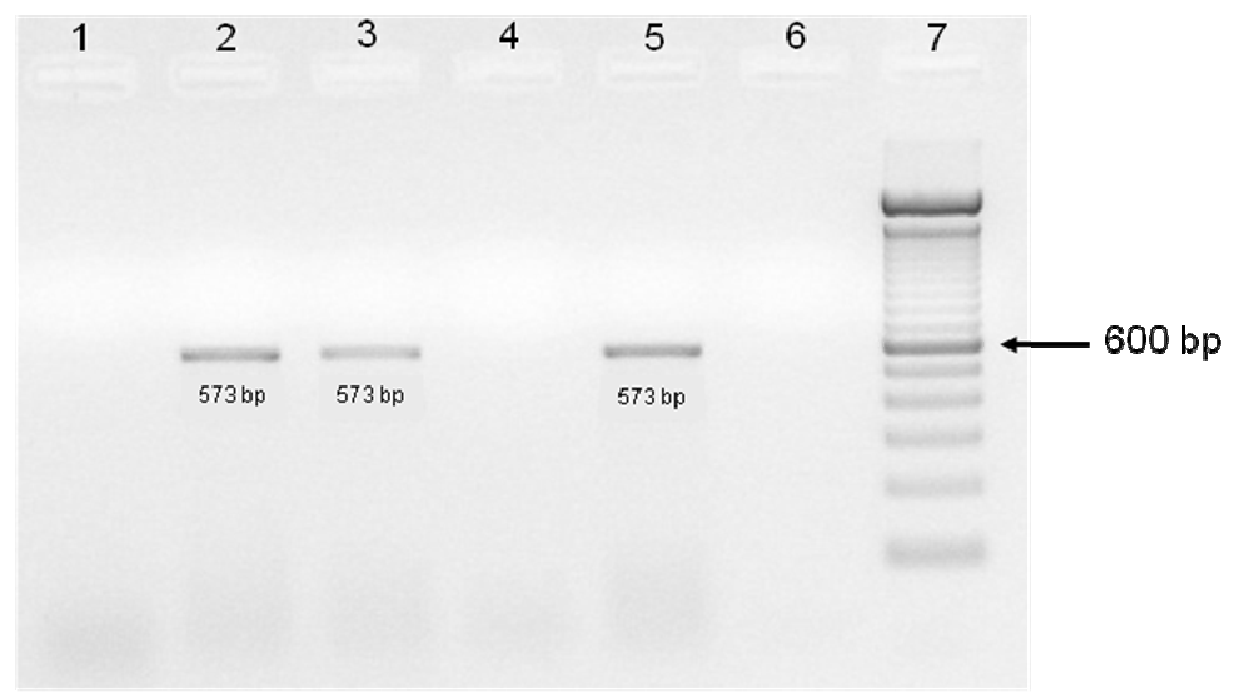

Figura 9. PCR de punto final para la detección del gen $I p f A_{0113}$. Calle 1 : mezcla de reacción sin ADN templado (control de sistema). Calle 2: cepa 187/06(22) silvestre. Calle 3: cepa 187/06(22) $\Delta / p f A_{0113}$ (pWSK:Ipf). Calle 4: cepa 187/06(22) $\Delta / p f A_{0113}$. Calle 5: cepa EH41 (control positivo). Calle 6: cepa EH41 $\Delta / p f A_{0113}$. Calle 7: Marcador de peso molecular $100 \mathrm{pb}$ (Cienmarker).

\section{6.- Contribución de Lpf a la adherencia de la cepa STEC 0136:H12}

A partir de los resultados anteriormente citados, se desafiaron las cepas 187/06(22) silvestre, $187 / 06(22) \Delta / p f A_{0113}$ y $187 / 06(22) \Delta / p f A_{0113}$ (pSWK:lpf) sobre distintas líneas celulares para observar si este gen estaba involucrado en la adherencia o invasión de las cepas in vitro.

Tal como puede observarse en la Figura 10, el agregado de manosa al medio inhibió la adherencia de las cepas a la línea celular T84. En estudios previos se observó que las cepas delecionadas para el elemento invertible fimA son incapaces de expresar la fimbria de tipo 1 capaz de unir manosa y sus derivados. Sin embargo, las cepas estudiadas en el presente trabajo contienen un locus Ipf que comparte cierta homología con la fimbria de tipo 1. Por lo tanto, estos resultados coinciden con 
las observaciones realizadas por Farfan y col. (2011) quienes indicaron que la manosa disminuye el pegado de Lpf a las proteínas de matriz extracelular. Debido a este resultado, los ensayos de adherencia subsiguientes se realizaron en ausencia de manosa para no inhibir la actividad de Lpf.

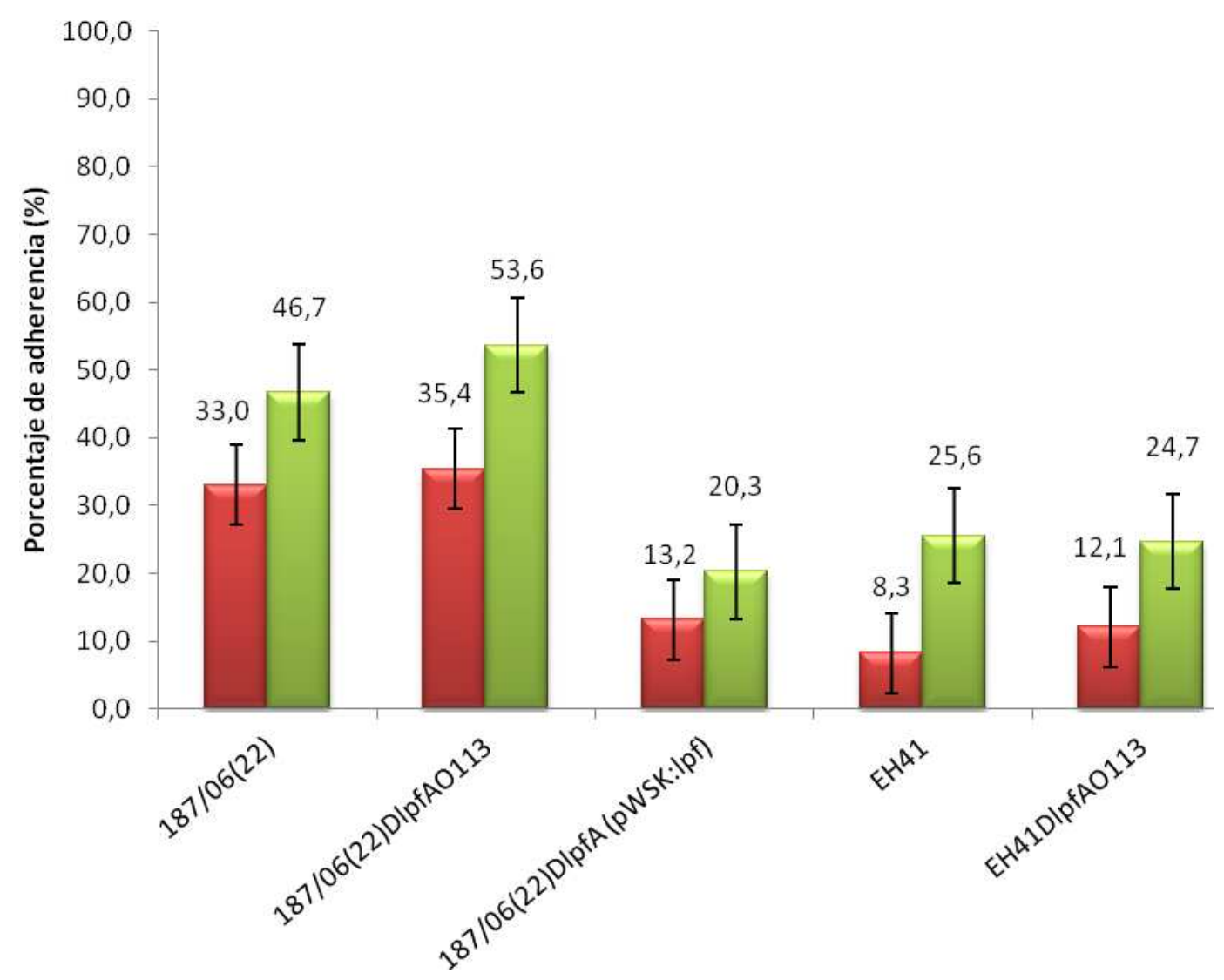

Figura 10. Ensayo de adherencia bacteriana in vitro a T84, en presencia (barras rojas) o ausencia (barras verdes) de manosa al $0,5 \%$. Porcentaje de adherencia de las cepas 187/06(22) silvestre, mutante para IpfA $A_{0113}$ y complementada, utilizando como control positivo la cepa EH41.

Los ensayos de adherencia bacteriana in vitro reflejaron que la adherencia de las cepas es dependiente del tipo de línea celular utilizada, como puede observarse en la Figura 11. En la gráfica se ve reflejado que la cepa 187/06(22) y sus derivadas, presentan una elevada adherencia a la línea celular T84, lo que estaría sugiriendo 
que además de adherirse, las bacterias se estarían multiplicando durante el período de incubación de $3 \mathrm{~h}$, ya que el número de microorganismos recuperados fue superior al de infección. En base a esta observación, se realizó un ensayo de cinética de adherencia por parte de las bacterias a la línea celular T84 y un ensayo de invasión para confirmar si las bacterias eran internalizadas y se multiplicaban en el interior celular.

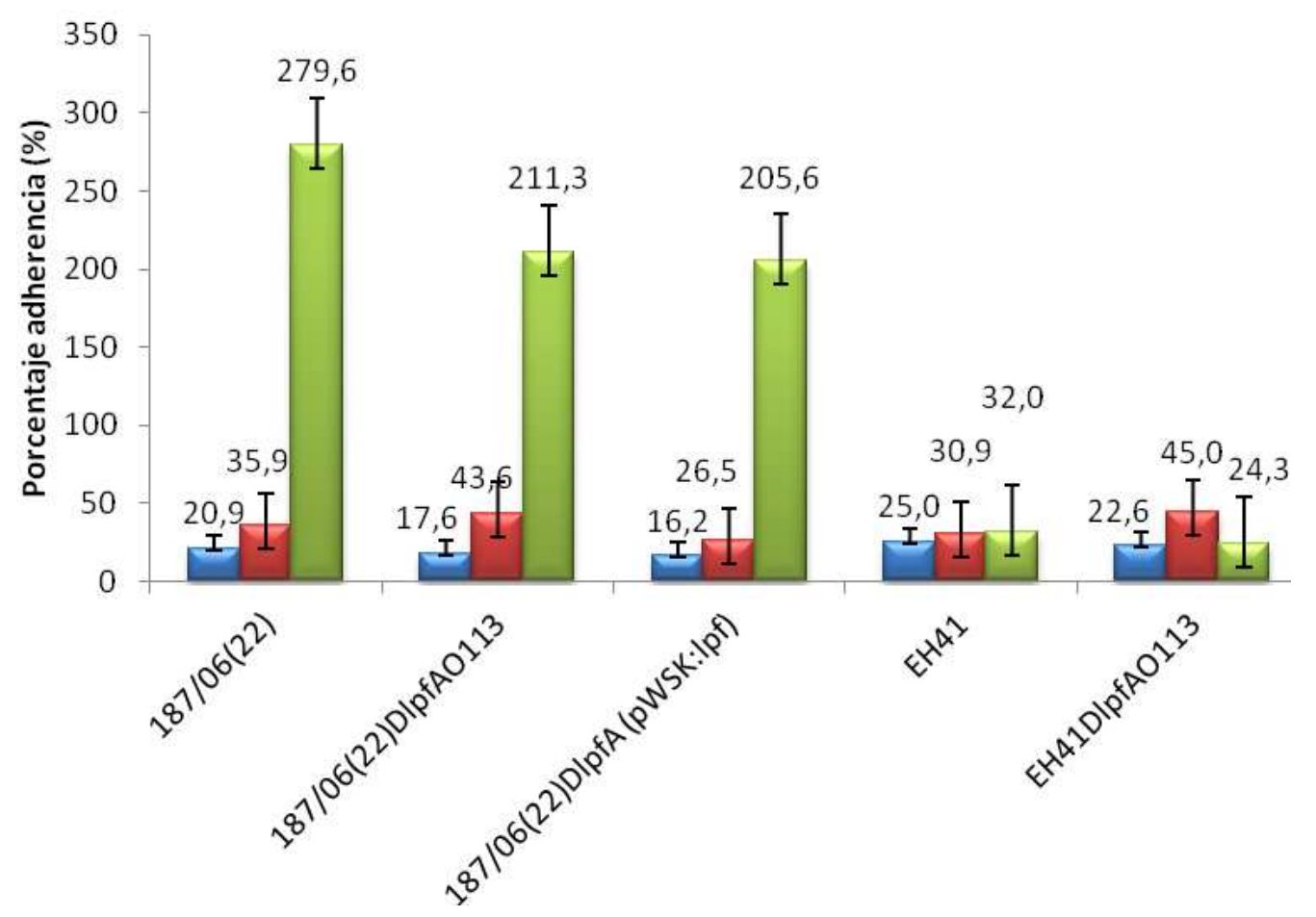

Figura 11. Gráfico comparativo de los ensayos de adherencia bacteriana in vitro a las líneas celulares Caco-2, HEp-2 y T84. El porcentaje de adherencia se expresó como el número de UFC/ml de bacterias recuperadas, dividido el número de UFC/ml inicial, todo multiplicado por 100 (promedio \pm desviación estándar).

El ensayo de cinética de adherencia a T84 se realizó siguiendo el protocolo descripto en la sección ensayo cuantitativo de adherencia (ver Materiales y Métodos, sección 3.8.2), utilizando los tiempos de infección: 30 min, 1, 2, y 4 h. En la Figura 12 se presentan los resultados obtenidos del experimento, donde queda demostrada 
una cinética de adherencia rápida a esta línea celular, ya que a los 30 min puede observarse una alta tasa de recuperación bacteriana y a las $4 \mathrm{~h}$ prácticamente el porcentaje de adherencia duplica al número de infección. Estos resultados ratifican la alta afinidad de la cepa 187/06(22) y sus derivadas a la línea celular de carcinoma de colon.

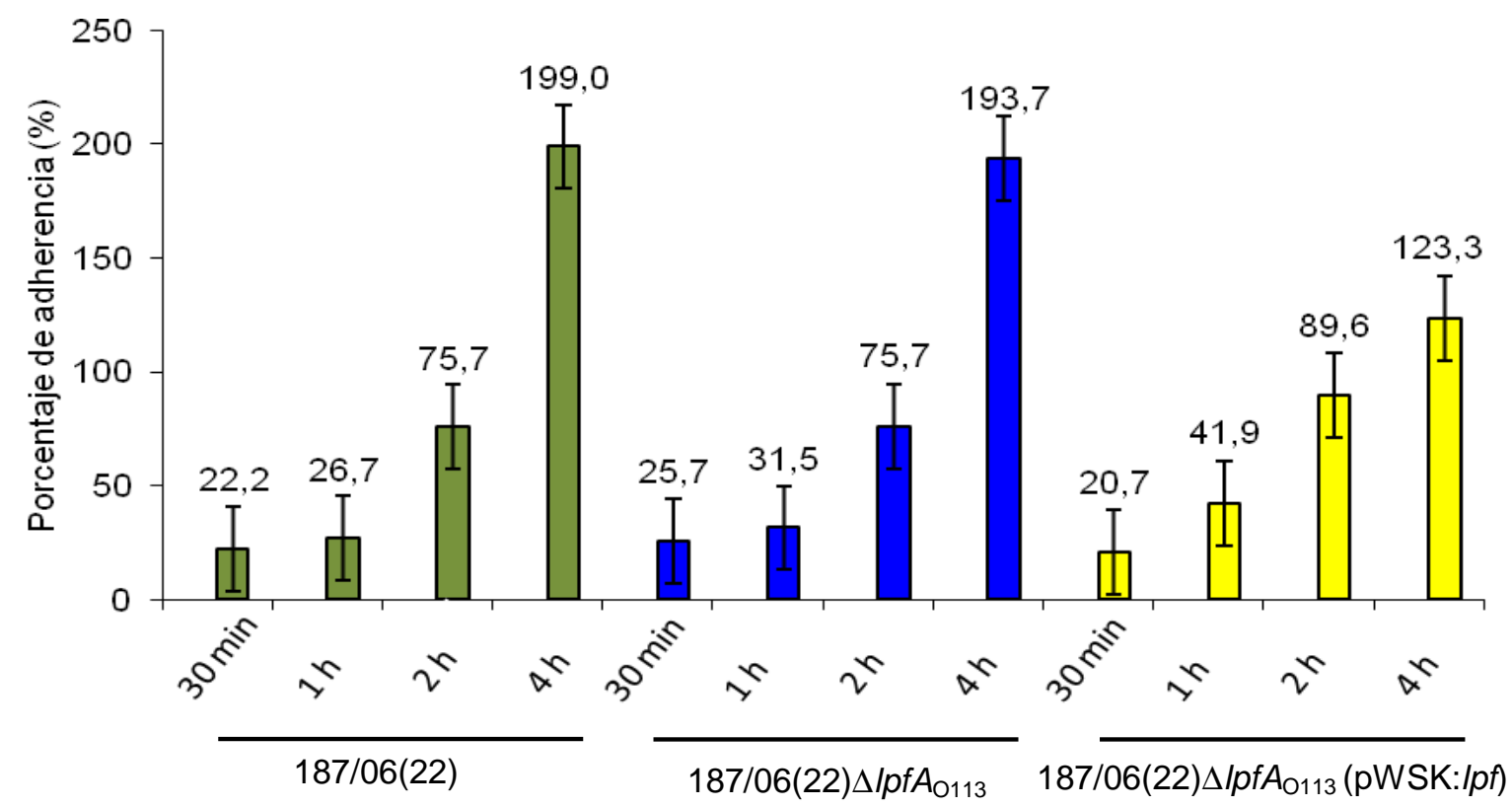

Figura 12. Cinética de adherencia de las cepas 187/06(22) (barras verdes), $187 / 06(22) \Delta / p f A_{0113}$ (barras azules) y $187 / 06(22) \Delta / p f A_{0113}$ (pWSK:/pf) (barras amarillas), a la línea celular T84, siendo los períodos de infección $30 \mathrm{~min}, 1$, 2, y 4 h. Este experimento fue realizado una sola vez por cuadruplicado.

Paso siguiente, se procedió a realizar los ensayos de invasión in vitro. Los experimentos reflejaron que la cepa 187/06(22) y sus derivadas no son invasivas si se las compara con el control positivo de invasión que es la cepa EH41 (Figura 13), de este resultado se desprende la hipótesis que la línea celular T84 posee algún receptor específico para las cepas estudiadas que hace que sean hiper-adherentes. 


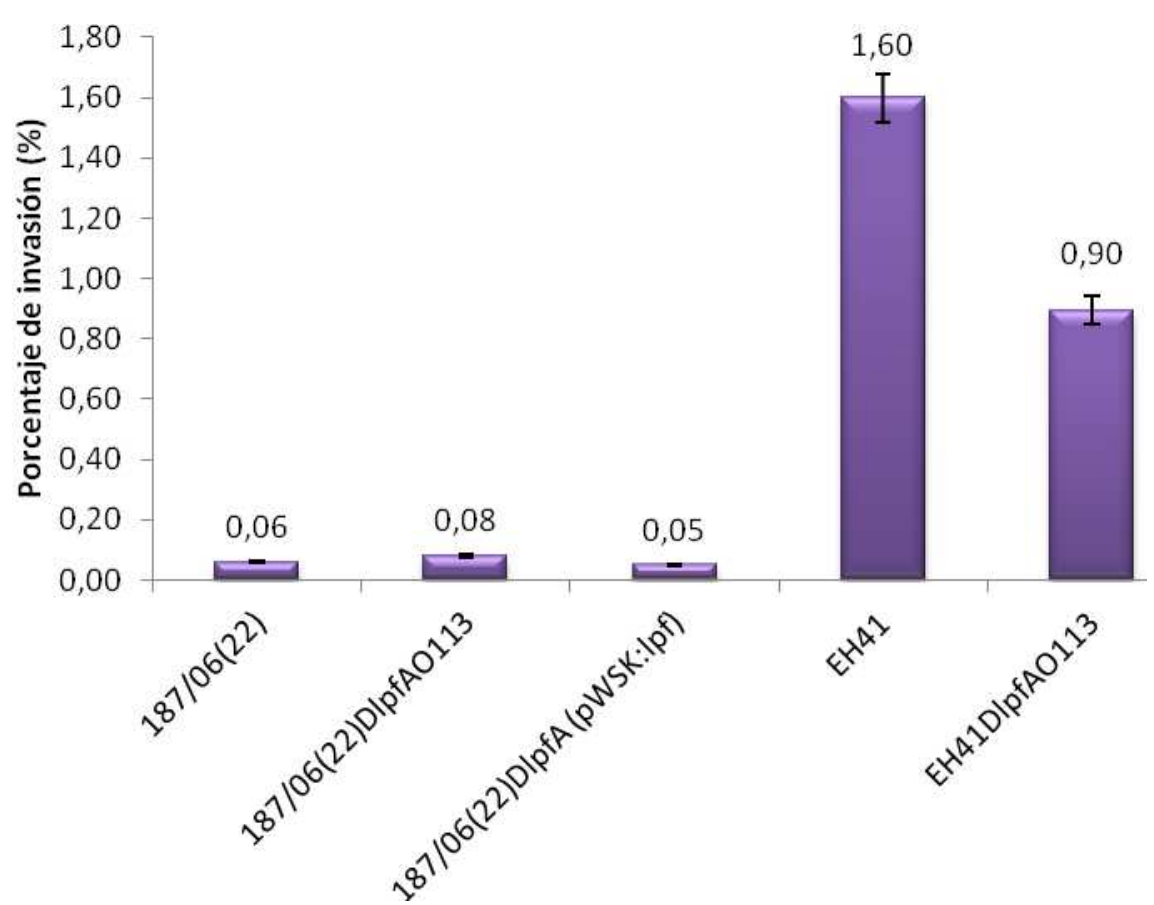

Figura 13. Ensayo de invasión in vitro a T84. El experimento se realizó por duplicado y cuadruplicado cada vez. La cepa EH41 se utilizó como control positivo de invasión.

Otro resultado que se ve reflejado en la Figura 11 es que no existe una diferencia significativa en la reducción de la adherencia por parte de la cepa mutante en $I p f A_{0113}$ si se la compara con la silvestre en las líneas celulares Caco-2 y HEp-2 $(p=0,42 ; p=0,10)$. Sin embargo, existe una diferencia significativa $(p<0,0002)$ en la línea celular T84. En los ensayos de competencia, la media del índice de competencia $(3,27 \pm 1,35)$ fue significativamente mayor a $1(p=0,043)$, indicando que la cepa mutante se adhiere más que la silvestre. Este descubrimiento inesperado sugiere que la cepa al carecer de Lpf como factor de adherencia estaría expresando un factor adicional que le proveería una ventaja en los ensayos de adherencia in vitro. En un estudio recientemente publicado por Lloyd y col. (2012), se describió una situación similar a la mencionada anteriormente, donde una cepa 0157:H7 doble mutante IpfA1/2 (ya que E. coli O157:H7 tiene dos operones de Lpf), presentó un 
aumento en la adherencia a líneas celulares in vitro. Mediante ensayos de microscopía electrónica de transmisión, se demostró la presencia de estructuras tipo curli, que fueron confirmadas a través ensayos de expresión fenotípica de curli, Western Blot, y PCR en tiempo real para medir la expresión de $\operatorname{csg} A$.

Siguiendo este razonamiento, se determinó la presencia del gen $\operatorname{csg} A$ en las cepas $187 / 06(22), 187 / 06(22) \Delta / p f A_{0113}$ y $187 / 06(22) \Delta / p f A_{0113}$ (pWSK:/pf), mediante PCR (Figura 14).

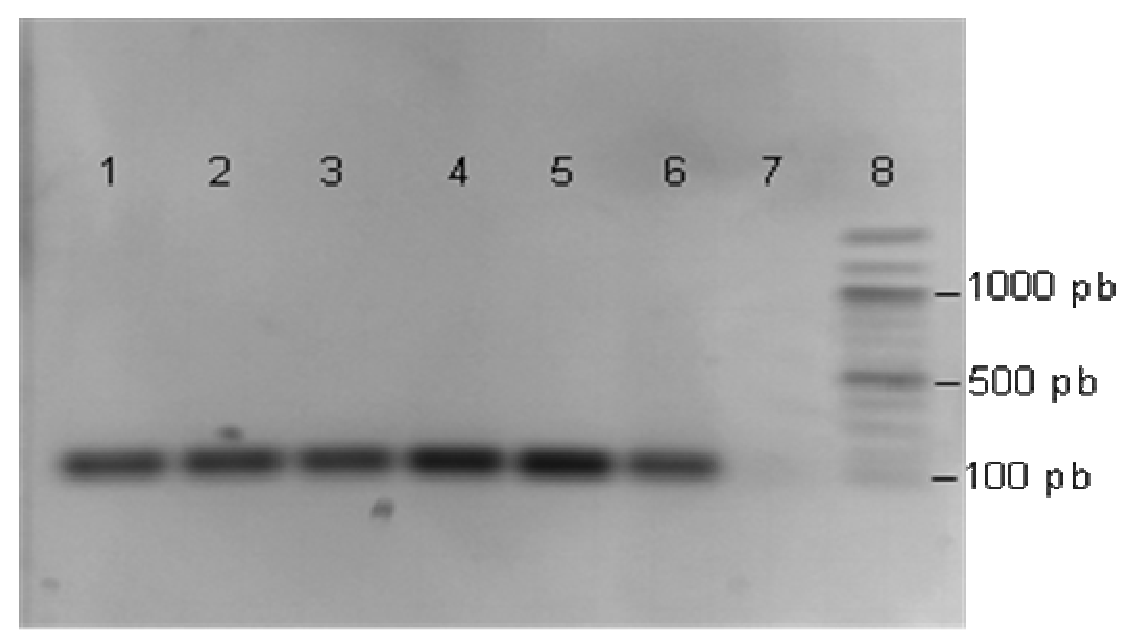

Figura 14. PCR de punto final para el gen csgA. Calle 1: cepa 187/06(22). Calle 2: $187 / 06(22) \Delta / p f A_{0113}$. Calle 3: $187 / 06(22) \Delta / p f A_{0113}$ (pWSK:/pf). Calle 4: EH41. Calle 5: EH41 $\Delta / p f A_{0113}$. Calle 6: 86-24 (O157:H7, control positivo). Calle 7: mezcla de reacción sin ADN templado (control de sistema). Calle 8: Marcador de peso molecular $100 \mathrm{pb}$ (Cienmarker).

Al observar que el gen se encontraba presente, se realizó el ensayo de expresión fenotípica de curli (ver Materiales y Métodos, sección 3.6), donde a diferencia del caso explicado anteriormente la cepa 187/06(22) silvestre y sus derivadas, no expresaron dicha fimbria. Como puede observarse en la Figura 15 (columna 2), la cepa O157:H7 doble mutante para IpfA1/2 cuando es sembrada en las placas indicadoras de rojo Congo, desarrolla una coloración rojiza consistente 
con la unión del colorante por curli. Del mismo modo, puede observarse que las cepas que no expresan dicha fimbria presentan una coloración más pálida, casi blanquecina, o no producen la coloración rojiza sólida (columnas 1, 3, 4-6).
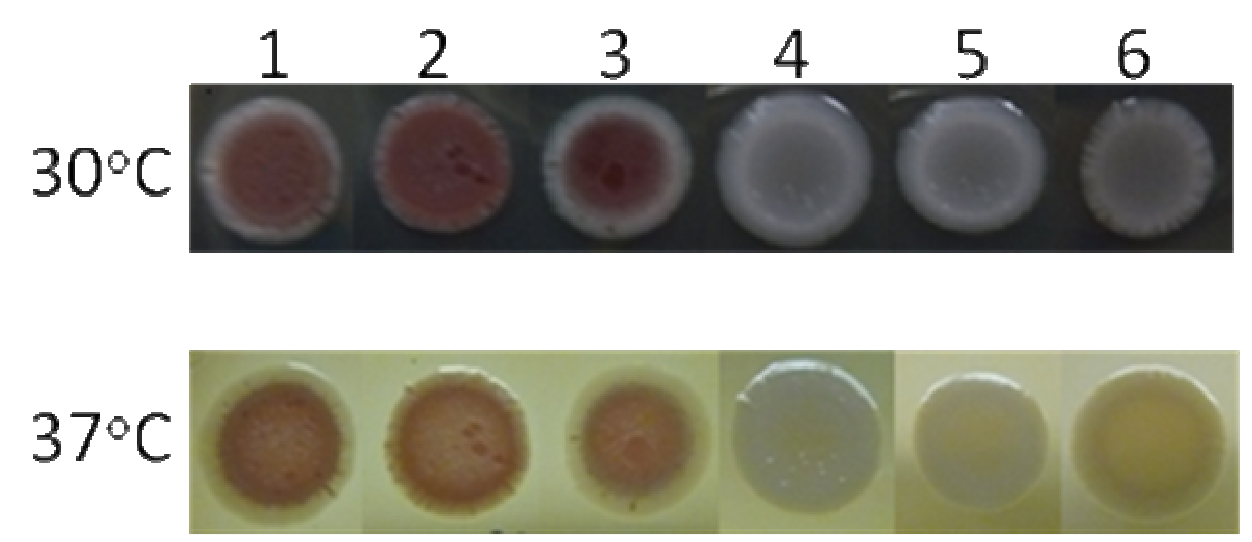

Figura 15. Ensayo de expresión de curli. Se crecieron las cepas 1) EHEC 86-24

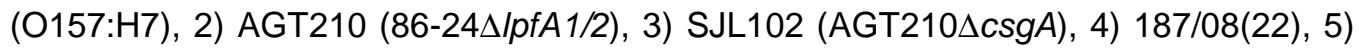
187/08(22) $\left.\Delta / p f A_{0113}, 6\right) 187 / 08(22) \Delta / p f A_{0113}$ (pWSK:Ipf), por 18 h. Se sembraron (6 $\mu \mathrm{l}$ ) en placas de LB-agar sin $\mathrm{NaCl}$ conteniendo $40 \mu \mathrm{g} / \mathrm{ml}$ de rojo Congo y $20 \mu \mathrm{g} / \mathrm{ml}$ de azul brillante de Coomassie y se incubaron por $24 \mathrm{~h}$ a $30^{\circ} \mathrm{C}$ ó $37^{\circ} \mathrm{C}$. La cepa AGT210 $(\triangle / p f A 1 / 2)$ fue utilizada como control positivo. La diferencia de color del fondo las fotos a $30^{\circ} \mathrm{C}$ ó $37^{\circ} \mathrm{C}$ se debe a artefactos de la toma de la foto.

En un intento por querer determinar la presencia de alguna otra adhesina no identificada anteriormente, se incubó la cepa 187/06(22) en diferentes medios de cultivo (LB, LB + dipiridil, DMEM, DMEM + dipiridil) a $30^{\circ} \mathrm{C}$ ó $37^{\circ} \mathrm{C}$. Se realizó una extracción de proteínas por calor (ver Materiales y Métodos, sección 3.13.1), se corrieron en un gel de poliacrilamida desnaturalizante al $10 \%$ y se enviaron a secuenciar tres bandas de aproximadamente $17 \mathrm{kDa}, 44 \mathrm{kDa}$ y $60 \mathrm{kDa}$ con aparente expresión inducida. El análisis de los resultados de espectrometría de masa no reflejó la secuencia de ninguna adhesina, sino que se obtuvieron secuencias similares a una proteína periplásmica de Shigella flexneri $(17 \mathrm{kDa})$, una proteína de unión a fosfato $(44 \mathrm{kDa})$ y una glutamato decarboxilasa de $E$. coli uropatogénica. 


\section{DISCUSION}

El conocimiento preciso de los factores que rigen la adherencia de STEC en los huéspedes animales, y el eventual desarrollo de una grave enfermedad en los seres humanos es imprescindible para lograr una intervención eficaz tendiente a evitar la colonización de este grupo bacteriano. Por otra parte, la definición de la combinación de genes de virulencia y los mecanismos que hacen que una cepa STEC sea potencialmente patogénica es fundamental para mejorar la eficacia tanto del diagnóstico de las infecciones en seres humanos como en la vigilancia de los reservorios animales y la evaluación de riesgos para la Salud Pública.

En los últimos diez años, el conocimiento sobre la epidemiología de las infecciones causadas por STEC avanzó notablemente. A nivel mundial, entre los años 2000 y 2005, los casos de enfermedad humana causados por STEC no-O157 aumentaron un $60,5 \%$, mientras que en el mismo período los casos causados por STEC 0157 aumentaron sólo un 13\% (Coombes y col., 2008). En vista del número creciente de informes sobre infecciones causadas por STEC no-0157 y puntualmente del brote en Alemania causado por una cepa STEC LEE-negativa, se pone en evidencia la falta de información de este heterogéneo grupo bacteriano y por ende la necesidad de investigar las bases moleculares para la virulencia, por lo que la prevalencia de adhesinas y otros marcadores de virulencia, junto a posibles mecanismos de patogenia en este tipo de cepas deben ser estudiados.

\section{1.- Prevalencia de factores de virulencia de cepas STEC LEE-negativas}

En este trabajo, se determinó la prevalencia de seis genes (incluídas sus variantes) que codifican para adhesinas o probables adhesinas, y tres genes que codifican 
para toxinas adicionales a las Stx, en un total de 200 cepas STEC LEE-negativas de 37 serotipos aisladas en Argentina a partir de ganado bovino y seres humanos con infección gastrointestinal.

En este estudio, la prevalencia de los genes $I p f A_{0113}$ e iha fue de 99,5\% y $86 \%$, respectivamente. Resultados similares fueron descriptos por Cergole-Novella y col. (2007), quienes encontraron $\operatorname{lpf} A_{0113}(89,2 \%)$ e iha $(87,6 \%)$ como las adhesinas más frecuentes. Toma y col. (2004) encontraron iha como la más prevalente $(91 \%)$, seguido por $I p f A_{0113}(73 \%)$; mientras que Tatarczak y col. (2005) describieron a toxB $(70,3 \%)$ como la más prevalente. Las principales diferencias entre los estudios podrían deberse al subgrupo de cepas estudiadas, ya que en los trabajos mencionados anteriormente se estudiaron en su mayoría cepas STEC LEEpositivas; en cambio, el presente trabajo se focalizó en el estudio del grupo de las STEC LEE-negativas. Por lo tanto, las diferencias en la frecuencia de las adhesinas identificadas podrían depender de las cepas caracterizadas en cada estudio.

En un trabajo publicado por Torres y col. (2009) se identificaron varios polimorfismos dentro del gen $I p f A$, que fueron utilizados para clasificar en variantes a la principal subunidad de esta fimbria. En este estudio se investigó la presencia de las variantes de IpfA tanto en las cepas aisladas de bovinos como en aquellas aisladas de infecciones humanas, encontrándose una prevalencia de IpfA1 y IpfA2 del $46 \%$ y $99,5 \%$, respectivamente. Del total de cepas estudiadas sólo una fue IpfAnegativa. La mayoría de las cepas portó la variante IpfA2-1 (99\%). Sin embargo, el $53 \%$ fue sólo IpfA2-1, mientras que el $46 \%$ fue positivo para la combinación de genes IpfA1-2 y IpfA2-1. 
Es interesante destacar que la variante más común identificada en las cepas de origen bovino fue IpfA2-1 (57,5\%). En cambio, en las cepas de origen humano la combinación de las variantes IpfA1-2 y IpfA2-1 fue la más prevalente $(57,4 \%)$. Estos hallazgos sugieren que la variante IpfA2-1 podría estar vinculada más a aquellos aislamientos que colonizan al ganado bovino, mientras que las cepas portadoras de la combinación IpfA1-2 y IpfA2-1 podrían llegar a tener la habilidad de colonizar el intestino humano y eventualmente ocasionar enfermedad. Es evidente que se requieren experimentos adicionales para confirmar la expresión de Lpf de estas cepas y establecer la asociación de determinadas variantes con enfermedad humana. Como primera aproximación los ensayos cualitativos de adherencia a células HEp-2 revelaron un patrón de adherencia diferente entre cepas con la variante IpfA2-3, que presentó un fenotipo parecido al de las cepas DAEC; y cepas IpfA2-1 que presentaron un tipo de adherencia localizado sobre las células.

De acuerdo con los resultados publicados por Torres y col. (2009) ninguna de las cepas estudiadas presentó las variantes IpfA1-3 o IpfA2-2 solas o combinadas. Por lo tanto, el presente estudio apoya la observación que estas variantes se encuentran específicamente en cepas 0157:H7 y O55:H7 (su ancestro). Hasta el presente, sólo se vinculó la asociación entre IpfA e intimina, indicando que diferentes alelos de intimina están relacionados con variantes de IpfA específicas (Torres y col., 2009), lo que condujo al desarrollo de una PCR múltiple que incluye los cebadores de variantes de IpfA específicas permitiendo la detección de serotipos específicos de STEC y EPEC (Botkin y col., 2012). Sin embargo, el trabajo de Torres y col. (2009) no incluye cepas STEC LEE-negativas, una diferencia notable con el presente estudio, porque a pesar que algunos de sus hallazgos son corroborados, nosotros 
encontramos evidencias de la distribución de variantes de IpfA en otras cepas STEC que también son patógenas para el hombre.

Ninguna de las cepas STEC LEE-negativas estudiadas portaron el gen efa1 ni tox $B$, corroborando la estrecha asociación entre estos genes y cepas intiminapositivas (Toma y col., 2004; Tatarczak y col., 2005). Este es el primer trabajo en el que se estudió ampliamente el gen fimA y se lo encontró en el 93,5\% de las cepas STEC LEE-negativas. Los hallazgos condicen con la presencia de esta adhesina en la mayoría de las cepas de E. coli comensales, lo que sugiere que la presencia de estas fimbrias podría contribuir en los primeros pasos de la adherencia a las células epiteliales.

Varios autores describieron la producción de otras toxinas, como CDT-V y SubAB, y propusieron su posible rol en la patogénesis de las infecciones causadas por STEC (Bielaszewska y col., 2005; Talbot y col., 2005). En este trabajo se demostró que el gen cdt-V estuvo presente en el $12 \%$ y el $17 \%$ de las cepas animales y humanas; y subAB en el $36 \%$ y $32 \%$, respectivamente. La frecuencia de detección de cdt-V fue mayor en las cepas humanas que en las de ganado bovino. Aunque Cergole-Novella y col. (2007) observaron que los genes de estas nuevas toxinas estaban presentes sólo en cepas LEE-negativas aisladas de bovinos, es importante mencionar que en el presente estudio, $c d t-\mathrm{V}$ y subAB se encontraron en cepas STEC aisladas de casos graves de enfermedad humana. Por lo tanto, la relevancia clínica aparente no debe ser ignorada, ya que especialmente se identificaron en serotipos de STEC, como O113:H21, O91:H21, O130:H11 y O163:H19, relacionados con casos de SUH en todo el mundo (http://www.lugo.usc.es/ecoli/SEROTIPOSHUM.htm). Asimismo, nuevos serogrupos 
portadores del gen $s u b A B$ fueron identificados por primera vez en este estudio como 07, O39, O74, O116 y 0130. Por otra parte, la presencia simultánea de cdt-V y subAB fue identificada en un vasto grupo de serotipos como O7:H21, O8:H19, O91:H21, O116:H21, O163:H19, O174:H28, O178:H19, ONT:H25 y ONT:H46, algunos de los cuales causan enfermedad en humanos. La secuencia del gen ast $A$ se encontró presente en el $9,8 \%$ y el $10,6 \%$ de las cepas animales y humanas, respectivamente. Es importante señalar que existió una asociación entre el genotipo stx específico de las cepas humanas astA-positivas, ya que todas fueron $s t x_{2 \mathrm{~d} 2}$, excepto una que fue $s t x_{2 a}$. Sin embargo, las cepas de ganado fueron principalmente stx $1 \mathrm{a}$.

El perfil de virulencia observado con mayor frecuencia entre las cepas estudiadas coincidentemente fue IpfA $_{0113} / \mathrm{iha}$ fimA, el cual estuvo presente en diez serotipos y en cepas no tipificables. Si bien el SUH presenta una etiología multifactorial, involucrando complejas interacciones de variables dependientes de la bacteria y del hospedador, en este trabajo se demostró que las cepas aisladas de 15 de los 19 casos de SUH estudiados portaron los genes $/ p f A_{0113} /$ ihal fimA. Se pudo observar una gran diversidad de serotipos y perfiles de virulencia entre las cepas STEC LEE-negativas de origen bovino y humano, sin embargo, ocho de los 11 perfiles coincidieron en ambos grupos. Estas pruebas refuerzan la teoría que el ganado es el principal reservorio natural de STEC y el principal origen de las infecciones en el ser humano. 


\section{2.- Capacidad de adherencia de cepas STEC LEE-negativas}

Se intentaron dilucidar los posibles mecanismos de adherencia de las cepas STEC LEE-negativas a células epiteliales. Se seleccionó un grupo de aislamientos con patrones únicos de adherencia establecidos a través de ensayos de adherencia in vitro. Para caracterizar mejor el rol del operón Ipf $_{0113}$ en la adherencia, se construyó una cepa mutante en la subunidad principal (LpfA) de la fimbria.

En estudios previos se demostró que la expresión del operón Ipfo113 en una cepa de E. coli no fimbriada presentaba una adherencia elevada a células CHO-K1.

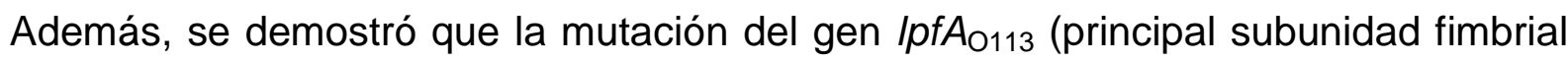
de Lpf) en una cepa STEC O113:H21 (EH41), resultó en una reducción de la adherencia a células en cultivo in vitro y cuando la cepa delecionada era complementada en trans con Ipfo113, reestablecía la adherencia a niveles similares a la cepa silvestre (Doughty y col., 2002). Sin embargo, en estudios posteriores se determinó que la cepa EH41 era capaz de invadir células colónicas humanas de forma rápida (Luck y col., 2005), aunque ese fenotipo no se asoció a Lpf, sino que se relacionó a $\mathrm{FliC}_{\mathrm{H} 21}$ y fue dependiente de la temperatura y del tipo flagelar, ya que en una cepa fli $C_{\mathrm{H} 21}$ mutante se observó una capacidad reducida de invasión a células HCT-8 y sólo se reestableció parcialmente cuando fue complementada con su respectivo flagelo y no con otro aleatorio (Luck y col., 2006).

Otros estudios también demostraron que tanto los operones lpf1 como Ipf2 de E. coli O157:H7 participan en la adherencia bacteriana en cultivo in vitro, ya que cepas mutantes en los genes IpfA1 y IpfA2 mostraron una reducción en la capacidad de adherencia a células epiteliales (Torres y col., 2002; Torres y col., 2004). En cambio, en el presente trabajo se demostró que la adherencia de las bacterias es 
dependiente de la línea celular utilizada y no se pudo establecer una relación directa entre adherencia y la presencia de Ipf, ya que en una cepa O136:H12 delecionada en $I p f A_{0113}$ no se observaron diferencias significativas respecto de la adherencia al compararla con la silvestre.

A diferencia de las observaciones de Luck y col. (2005), en este estudio tampoco se vió que las cepas LEE-negativas fueran invasivas. Por lo tanto, la hipótesis que las cepas STEC LEE-negativas podrían emplear un mecanismo de invasión celular del huésped para colonizar el epitelio intestinal como medio de patogenia alternativo de forma de compensar la ausencia de LEE y la incapacidad de formar lesión $A / E$, sería válida solamente para algunas cepas STEC LEEnegativas. Asimismo, teniendo en cuenta la información proporcionada por la secuencia de la cepa del brote de Alemania, que demostró que la cepa tenía una base genética de EAEC pero portaba la codificación mediada por fagos para Stx2, y las observaciones de Luck y col. (2005), se podría especular que algunas bacterias del amplio grupo de las cepas STEC LEE-negativas podrían tener la base genética de cualquiera de las categorías de $E$. coli patogénicas, pero que por algún evento evolutivo adquierieron los fagos que codifican para las toxinas Shiga. Un indicio de esta especulación que se ve reflejada en el trabajo podrían ser las cepas STEC LEEnegativas ast $A$-positivas, ya que este tipo de toxinas es característico de las cepas EAEC.

Cabe destacar que se observó solamente una diferencia estadísticamente significativa en la reducción de la adherencia a la línea celular T84 por parte de la cepa mutante, pero no se reestablecieron los valores de adherencia de la cepa silvestre cuando la mutante fue complementada con el plásmido que tenía clonado el 
operón completo de $I p f A_{0113}$. Además, en esta línea celular las cepas O136:H12 y sus derivadas (mutante para $I p f A_{0113}$ y complementada) presentaron una adherencia elevada, sugiriendo que esta línea en particular posee alguna capacidad inherente que hace que las bacterias se adhieran más que a otras líneas celulares como Caco2 o HEp-2. Estos resultados sugieren la existencia de algún tipo de receptor específico para alguna adhesina no identificada en las cepas en estudio, ya que a pesar de obtener una reducción significativa en la adherencia por parte de la cepa mutante en $I p f A_{0113}$, las cepas continúan uniéndose elevadamente a esta línea celular.

Los ensayos de competecia en células Caco-2 en cambio, revelaron que la cepa $187 / 08(22) \Delta / p f A_{0113}$ fue más adherente que la cepa silvestre. Coincidentemente, un estudio reciente publicado por Lloyd y col. (2012), estableció que una cepa O157:H7 doble mutante para Ipf ( $\triangle / p f A 1 / 2)$ fue más adherente en cultivo celular in vitro que su respectiva silvestre. Los investigadores encontraron que al mutar ambos operones de Ipf, la cepa comenzaba a expresar mayores niveles de curli, permitiéndole adherirse aún más a la línea celular in vitro. En el presente estudio se encontró que las cepas estudiadas portaban el gen que codifica para la principal subunidad fimbrial de curli $(\operatorname{csg} A)$, pero a diferencia de lo descubierto por Lloyd y col. (2012) esta fimbria no se expresaba fenotípicamente, aún en la cepa mutante para IpfA. Estos resultados sugieren que podría llegar a existir otra fimbria no identificada en este estudio (el presente estudio se centralizó en el estudio de adhesinas principalmente descriptas en cepas de origen humano, pero no se investigaron aquellas específicas de reservorio animal como F9 o F17, entre otras), que se estaría expresando bajo una situación de estrés, como podría ser en este 
caso la mutación de Ipf. A pesar de no poder identificar otra adhesina, estas observaciones indican que los mecanismos regulatorios de la expresión de Lpf y otra adhesina alternativa son interdependientes. Otra hipótesis podría ser que dentro de la secuencia de IpfA2 se encuentre un sitio de unión específico para algún regulador transcripcional de otra fimbria y por ello cuando se muta una cepa en Ipf2 se observa mayor adherencia in vitro.

Otro tema a tener en cuenta es la regulación del operón Ipf2 en cepas STEC LEE-negativas, ya que sólo se describió en profundidad la regulación del operón Ipf1 de cepas 0157:H7. En el caso del operón Ipf1, se determinó que se regula en respuesta a la fase de crecimiento del microorganismo, de la temperatura y del $\mathrm{pH}$ (Torres y col., 2007a). Asimismo, se demostró que el mecanismo de silenciamiento/anti-silenciamiento está regulado por las proteínas H-NS y Ler (Torres y col., 2007b), y en un estudio recientemente publicado se describieron los sitios específicos de unión de dichas proteínas (Rojas-López y col., 2011).

En cambio, se conoce muy poco sobre los mecanismos de regulación del operón Ipf2. Mediante ensayos de fusión transcripcional se observó que este operón se induce in vitro en la fase de crecimiento tardía del microorganismo a $37^{\circ} \mathrm{C}$. Además, la expresión de lpf2 se vió estimulada en medio mínimo restringido en la concentracion de hierro, sugiriendo que la expresión de este operón podría estar regulado por la proteína Fur (Torres y col., 2007a). En otro trabajo se describió que la expresión de Ipf2 se encuentra influenciada por la fuente de carbono y la ausencia de hierro en el medio (Lymberopoulos y col., 2006). Sin embargo, se requieren más estudios que corroboren la función de Fur como reguladora de Ipf2. 
Las cepas STEC LEE-negativas al carecer de esta isla de patogenicidad, tampoco poseen la proteína Ler, por lo tanto en este grupo bacteriano la expresión de Lpf no puede estar regulada por esta proteína, y a pesar que se realizaron algunos intentos por dilucidar el mecanismo de regulación de lpf2 (datos no mostrados), poco se conoce sobre su expresión.

La principal subunidad fimbrial $\operatorname{Lpf}_{0113}$ pertenece a la familia de las fimbrias de tipo 1, como tal posee residuos de cisteína conservados que forman puentes disulfuro con otras proteínas, también poseen un dominio de unión a chaperona característico por un residuo invariable de glicina y residuos aromáticos separados por una serie alternada de residuos hidrofóbicos (Dougthy y col., 2002). Por su alta homología con las fimbrias de tipo 1 también podría hipotetizarse que la expresión de IpfA estuviera regulada por una fase de encendido y apagado como fimA, pero se requieren estudios adicionales para dilucidar el complejo mecanismo de expresión y patogénesis del operón lpf2. 


\section{CONCLUSIONES}

6.1.- Se realizó por primera vez un estudio en el que se determinó la presencia de los genes que codifican para seis adhesinas putativas y tres toxinas, además de las Stx, en una colección de 200 cepas aisladas en Argentinas de reservorio animal y de infecciones intestinales humanas causadas por STEC LEE-negativas.

6.2.- Se demostró que las cepas STEC LEE-negativas bovinas poseen genes que codifican para adhesinas putativas y las toxinas presentes en las cepas STEC LEEnegativas aisladas de casos de enfermedad en humanos.

6.3.- A pesar de la diversidad de los perfiles de virulencia observados entre las cepas estudiadas, se identificó una asociación característica entre perfiles de virulencia, serotipos y fuente de aislamiento.

6.4.- Se confirmó que las cepas STEC LEE-negativas no son un grupo clonal de patógenos, ya que se observaron diferencias en los perfiles de virulencia, incluso en cepas del mismo serotipo. Si bien algunos determinantes no pueden considerarse factores esenciales de virulencia para las infecciones humanas, podrían facilitar la supervivencia y la persistencia de las cepas en diferentes ambientes.

6.5.- A pesar del gran esfuerzo por querer determinar alguno de los mecanismos en las primeras etapas de la patogenia de las cepas STEC LEE-negativas, en el presente trabajo se demostró que en las condiciones ensayadas, Lpf2 no es la 
adhesina principal participando de los mecanismos de pegado o interaccion a células epiteliales in vitro.

6.6.- Se requieren estudios adicionales para determinar el papel exacto de cada factor en la patogénesis de las cepas STEC LEE-negativas.

6.7.- Es de vital importancia para la Salud Pública y los laboratorios clínicos reconocer las cepas STEC LEE-negativas como causa de infección en humanos e incluirlos en el sistema de vigilancia. 


\section{PERSPECTIVAS A FUTURO}

7.1.- Encontrar las posibles adhesinas que están participando en la adherencia de la cepa O136:H12 in vitro.

7.2.- Identificar los principales mecanismos de regulación de la expresión del operón Ipf2 en cepas STEC LEE-negativas.

7.2.- Determinar la contribución de Lpf2 in vivo. 


\section{BIBLIOGRAFIA}

1. Abaas S, Franklin A, Kühn I, Ørskov F, Ørskov I. Cytotoxin activity on Vero cells among Escherichia coli strains associated with diarrhea in cats. Am J Vet Res. 1989;50:1294-1296.

2. Abraham JM, Freitag CS, Clements JR, Eisenstein BI. An invertible element of DNA controls phase variation of type 1 fimbriae of Escherichia coli. Proc Natl Acad Sci USA. 1985;82:5724-5727.

3. Abu-Median AB, Van Diemen PM, Dziva F, Vlisidou I, Wallis TS, Stevens MP. Functional analysis of lymphostatin homologues in enterohaemorrhagic Escherichia coli. FEMS Microbiol Lett. 2006;258:43-49.

4. Bardiau M, Labrozzo S, Mainil JG. Putative adhesins of enteropathogenic and enterohemorrhagic Escherichia coli of serogroup $\mathrm{O} 26$ isolated from humans and cattle. $\mathrm{J}$ Clin Microbiol. 2009;47:2090-2096.

5. Barnhart MM, Chapman MR. Curli biogenesis and function. Annu Rev Microbiol. 2006;60:131-147.

6. Barret TJ, Lior H, Green JH, Khakhria R, Wells JG, Bell BP, Greene KD, Lewis J, Griffin PM. Laboratory investigation of a multistate food-borne outbrake of Escherichia coli O157:H7 by using pulsed-field gel electrophoresis and phage typing. J Clin Microbiol. 1994;32:3013-7.

7. Baümler AJ, Heffron F. Identification and sequence analysis of IpfABCDE, a putative fimbrial operon of Salmonella typhimurium. J Bacteriol. 1995;177:2087-2097.

8. Bell BP, Griffin PM, Lozano P, Christie DL, Kobayashi JM, Tarr PI. Predictors of hemolytic-uermic syndrome in children during a large outbreak of Escherichia coli $\mathrm{O} 157: \mathrm{H} 7$ infections. Pediatrics. 1997;100:E12.

9. Bentancor A, Rumi MV, Gentilini MV, Sardoy C, Irino K, Agostini A, Cataldi A. Shiga toxin-producing and attaching and effacing Escherichia coli in cats and dogs in a high hemolytic uremic syndrome incidence region in Argentina. FEMS Microbiol Lett. 2007;267:251-256. 
10. Best A, La Ragione RM, Sayers AR, Woodward MJ. Role for flagella but not intimin in the persistent infection of the gastrointestinal tissues of specific-pathogen-free chickens by shiga toxin-negative Escherichia coli O157:H7. Infect Immun. 2005;73:1836-1846.

11. Beutin L, Geier D, Steinrück H, Zimmermann S, Scheutz F. Prevalence and some properties of verotoxin (Shiga-like toxin)-producing Eschericha coli in seven different species of healthy domestic animals. J Clin Microbiol. 1993;31:2483-2488.

12. Bielaszewska M, Fell M, Greune L, Prager R, Fruth A, Tschape H, Schmidt MA, Karch $\mathrm{H}$. Characterization of cytolethal distending toxin genes and expression in Shiga toxinproducing Escherichia coli strains of non-O157 serogroups. Infect Immun. 2004;72:18121816.

13. Bielaszewsaka M, Sinha B, Kuczius T, Karch H. Cytolethal distending toxin from Shigatoxin Escherichia coli 0157 causes irreversible G2/M arrest, inhibition of polifarantin, and death of human endothelial cells. Infect Immun. 2005;73:552-562.

14. Bielaszewska M, Mellmann A, Zhang W, Köck R, Fruth A, Bauwens A, Peters G, Karch $\mathrm{H}$. Characterisation of the Escherichia coli strain associated with an outbreak of haemolytic uraemic syndrome in Germany, 2011: a microbiological study. Lancet Infect Dis. 2011;11:671-676.

15. Botkin DJ, Galli L, Sankarapani V, Soler M, Rivas M, Torres AG. Development of a multiplex PCR assay for detection of pathogenic Escherichia coli strains. Front Cell Inf Microbio. 2012;2:8. doi: 10.3389/fcimb.2012.00008. En prensa.

16. Bürk $C$, Dietrich $R$, Açar $G$, Moravek $M$, Bülte $M$, Märtlbauer $E$. Identification and Characterization of a new variant of Shiga toxin 1 in Escherichia coli ONT:H19 of bovine origin. J Clin Microbiol. 2003;4:2106-2112.

17. Buteau C, Proulx F, Chaibou M, Raymond D, Clermont MJ, Mariscalco MM, Lebel MH, Seidman E. Leukocytosis in children with Escherichia coli O157:H7 enteritis developing the hemolytic-uremic syndrome. J Pediatr Infect Dis. 2000;19:642-647. 
18. Caprioli A, Morabito S, Brugère H, Oswald E. Enterohaemorrhagic Escherichia coli: emerging issues on virulence and modes of transmission. Vet Res. 2005;36:289-311.

19. Carter AO, Borczyk AA, Carlson JA, Harvey B, Hockin JC, Karmali MA, Krishnan C, Korn DA, Lior H. A severe outbreak of Escherichia coli O157:H7-associated hemorragic colitis in a nursing home. N Engl J Med. 1987;317:1496-1500.

20. Castillo A, Eguiarte LE, Souza V. A genomic population genetics analysis of the pathogenic enterocyte effacement island in Escherichia coli: The search for the unit of selection. PNAS. 2005;102:1542-1547.

21. Cergole-Novella MC, Nishimura LS, Dos Santos LF, Irino K, Vaz TM, Bergamini AM, Guth BEC. Distribution of virulence profiles related to new toxins and putative adhesins in Shiga toxin-producing Escherichia coli isolated from diverse sources in Brazil. FEMS Microbiol Lett. 2007;274:329-334.

22. Chapman PA, Siddons CA, Wright DJ. Cattle as a possible source of verocytoxinproducing Escherichia coli O157 infections in man. Epidemiol Infect. 1993;111:439-447.

23. Chen CY, Nace GW, Irwin PL. A $6 \times 6$ drop plate method for simultaneous colony counting and MPN enumeration of Campylobacter jejuni, Listeria monocytogenes, and Escherichia coli. J Microbiol Methods. 2003;55:475-479.

24. Chinen I, Epszteyn S, Melamed CL, Aguerre L, Martínez Espinosa E, Motter MM, Baschkier A, Manfredi E, Miliwebsky E, Rivas M. Shiga toxin-producing Escherichia coli O157 in beef and chicken burgers, and chicken carcasses in Buenos Aires, Argentina. Int $\mathrm{J}$ Food Microbiol. 2009;132:167-171.

25. Cimolai N, Basalyga S, Mah DG, Morrison BJ, Carter JE. A continuing assessment of risk factors for the development of Escherichia coli O157:H7-associated hemolytic uremic syndrome. Clin Nephrol. 1994;42:85-89.

26. Comité de Nefrología. Incidencia del Síndrome Urémico Hemolítico (SUH) en la República Argentina. Arch Arg Pediatr. 1995;93:407-11. 
27. Collinson SK, Doig P, Doran JL, Clouthier SC, Trust T, Kay WW. Thin aggregative fimbriae mediate binding of Salmonella enteritidis to fibronectin. J Bacteriol. 1993;175:12-18.

28. Collinson SK, Clouthier SC, Doran JL, Banser PA, Kay WW. Salmonella enteritidis agfBAC operon encoding thin, aggregative fimbriae. J Bacteriol. 1996;178:662-667.

29. Coombes BK, Wickham ME, Mascarenhas M, Gruenheid S, Finlay B, Karmali MA. Molecular analysis as an aid to assess the Public Health risk of Non-O157 Shiga toxinproducing Escherichia coli strains. Appl Eviron Microbiol. 2008;74:2153-2160.

30. Datsenko KA, Wanner BL. One-step inactivation of chromosomal genes in Escherichia coli K-12 using PCR products. Proc Natl Acad Sci USA. 2000;97:6640-6645.

31. Deacon V, Dziva F, van Diemen PM, Frankel G, Stevens MP. Efa-1/LifA mediates intestinal colonization of calves by enterohaemorrhagic Escherichia coli $\mathrm{O} 26: \mathrm{H}$ - in a manner independent of glycosyltransferase and cysteine protease motifs or effects on type III secretion. Microbiology. 2010;156:2527-2536.

32. Dean-Nystrom EA, Bosworth BT, Cray WC Jr, Moon HW. Pathogenicity of Escherichia coli O157:H7 in the intestines of neonatal calves. Infect Immun. 1997;65:1842-1848.

33. Doughty S, Sloan J, Bennet-Wood V, Robertson M, Robins-Browen RM, Hartland EL. Identification of a nobel fimbrial gene cluster related to long polar fimbriae in locus of enterocyte effacement-negative strains of enterohemorrhagic Escherichia coli. Infect Immun. 2002;70:6761-6769.

34. Dytoc MT, Ismaili A, Philpott DJ, Soni R, Brunton JL, Sherman PM. Distinct binding properties of eaeA-negative verocytotoxin-producing Escherichia coli of serotype O113:H21. Infect Immun. 1994;62:3494-3505.

35. Erdem AL, Avelino F, Xicohtencatl-Cortes J, Girón JA. Host protein binding and adhesive properties of $\mathrm{H} 6$ and $\mathrm{H} 7$ flagella of attaching and effacing Escherichia coli. $\mathrm{J}$ Bacteriol. 2007;189:7426-7435. 
36. Edwards RA, Puente JL. Fimbrial expression in enteric bacteria: a critical step in intestinal pathogenesis. Trends Microbiol. 1998;6:282-287.

37. Escherich, T. Die Darmbakterien des Neugeborenen un Säuglings. Fortschritte der Medizin. 1885;3:547-554.

38. Ewing WH, Edwards PR. Edwards and Ewing's Identification of Enterobacteriaceae. En: Ewing WH (Ed). New York: Elsevier; 1986.

39. Farfan MJ, Cantero L, Vidal R, Botkin DJ, Torres AG. The long polar fimbriae of enterohemorrhagic Escherichia coli $\mathrm{O} 157: \mathrm{H} 7$ binds to extracellular matrix proteins. Infect Immun. 2011;79:3744-3750.

40. Fitzhenry R, Dahan S, Torres AG, Chong Y, Heuschkel R, Murch S, Thomson M, Kaper JB, Frankel G, Phillips AD. Long polar fimbriae and tissue tropism in Escherichia coli O157:H7. Int J Med Microbiol. 2006;296:547-552.

41. Friedrich AW, Bielaszewska M, Zhang W, Pulz M, Kuczius $T$, Ammon A, Karch H. Escherichia coli harboring Shiga toxin 2 gene variants: Frequency and association with clinical symptoms. J Infect Dis. 2002;185:74-84.

42. Frydendahl K. Prevalence of serogroups and virulence genes in Escherichia coli associated with postweaning diarrhea and edema disease in pigs and a comparison of diagnostic approaches. Vet Microbiol. 2002;85:169-182.

43. Galli L, Miliwebsky E, Irino K, Leotta GA, Rivas M. Virulence profile comparison between LEE-negative Shiga toxin-producing Escherichia coli strains isolated from cattle and humans. Vet Microbiol. 2010a;143:307-313.

44. Galli L, Torres AG, Rivas M. Identification of the long polar fimbriae gene variants in the locus of enterocyte effacement-negative Shiga toxin-producing Escherichia coli strains isolated from humans and cattle in Argentina. FEMS Microbiol Lett. 2010b;308:123-129. 
45. Gally DL, Leathart J, Blomfield IC. Interaction of FimB and FimE with the fim switch that controls the phase variation of type 1 fimbriae in Escherichia coli K-12. Mol Microbiol. $1996 ; 21: 725-738$.

46. Gómez D, Miliwebsky E, Fernandez Pascua C, Baschkier A, Manfredi E, Zotta M, Nario F, Piquín A, Sanz M, Etcheverría A, Padola N, Parma A, Rimas M. Aislamiento y caracterización de Escherichia coli productor de toxina Shiga en hamburguesas supercongeladas y quesos de pasta blanda. Rev Arg Microbiol. 2002;34:66-71.

47. Goldberg MB, Boyko SA, Butterton JR, Stoebner JA, Payne SM, Calderwood SB. Characterization of a Vibrio cholerae virulence factor homologous to the family of TonBdependent proteins. Mol Microbiol. 1992;6:2407-2418.

48. Griffin PM, Bell BP, Cieslak PR, Tuttle J, Barret TJ, Doyle MP, y col. Large outbreak of Escherichia coli O157:H7 in the Western United States: the big picture. En: Recent advances in verocytotoxin-producing Escherichia coli infections. Karmali MA, Goglio AG (eds). Elsevier Amsterdam, Lausanne, New York, Oxford Shannon, Tokyo; 1994. p. 7-12.

49. Guth BEC, Prado V, Rivas M. Capítulo 5: Shiga toxin-producing Escherichia coli. En: Pathogenic Escherichia coli in Latin America. Torres AGT (eds). Bentam Science Publishers. April 2011, p. 65-83.

50. Gyles CL. Shiga toxin-producing Escherichia coli: An overview. J Anim Sci. 2007;85:E45-E62.

51. Hall TA. Bioedit: a user friendly biological sequence alignment editor and analysis program for Windows 95/98/NT. Nucl Acids Symp Ser. 1999;41:95-98.

52. Hamilton CM, Aldea M, Washburn BK, Babitzke $P$, Kushner SR. New method for generating deletions and gene replacements in Escherichia coli. J Bacteriol. 1989;171:46174622.

53. Hammermueller J, Kruth S, Prescott J, Gyles C. Detection of toxin genes in Escherichia coli isolated from normal dogs and dogs with diarrhea. Can J Vet Res. 1995;59:265-270. 
54. Hovde CJ, Austin PR, Cloud KA, Williams CJ, Hunt CW. Effect of cattle diet on Escherichia coli O157:H7 acid resistance. Appl Environ Microbiol. 1999;65:3233-3235.

55. lida KI, Mizunoe Y, Wai SN, Yoshida SI. Type 1 fimbriation and its phase switching in diarrheagenic Escherichia coli strains. Clin Diagn Lab Immunol. 2001;8:489-495.

56. Janka A, Bielaszewska M, Dobrindt U, Greune L, Schmidt MA, Karch H. Cytolethal distending toxin gene cluster in enterohemorrhagic Escherichia coli O157:H- and O157:H7: Characterization and evolutionary considerations. Infect Immun. 2003;71:3634-3638.

57. Jenkins C, Chart H, Smith HR, Hartland EL, Batchelor M, Delahay RM, Dougan G, Frankel G. Antibody response of patients infected with verocytotoxin-producing Escherichia coli to protein antigens encoded on the LEE locus. J Med Microbiol. 2000;49:97-101.

58. Jelacic JK, Damrow T, Chen GS, Jelacic S, Bielaszewska M, Ciol M, Caravalho HM, Melton-Celsa AR, O’Brien AD, Tarr PI. Shiga toxin-producing Escherichia coli in Montana: Bacterial genotypes and clinical profiles. J Infect Dis. 2003;188:719-729.

59. Johnson JR, Jelacic S, Schoening LM, Clabots C, Shaikh N, Mobley HL, Tarr PI. The IrgA homologue adhesin Iha is an Escherichia coli virulence factor in murine urinary tract infection. Infect Immun. 2005;73:965-971.

60. Jonas K, Tomenius H, Kader A, Normark S, Romling U, Belova LM, Melefors O. Roles of curli, cellulose and BapA in Salmonella biofilm morphology studied by atomic force microscopy. BMC Microbiol. 2007;7:70.

61. Jones CH, Pinkner JS, Roth R, Heuser J, Nicholes AV, Abraham SN, Hultgren SJ. FimH adhesin of type 1 pili is assembled into a fibrillar tip structure in the Enterobacteriaceae. Proc Natl Acad Sci USA. 1995;92:2081-2085.

62. Jordan DM, Cornick N, Torres AG, Dean-Nystrom EA, Kaper JB, Moon HM. Long polar fimbriae contribute to colonization by Escherichia coli 0157:H7 in vivo. Infect Immun. 2004;72:6168-6171. 
63. Jure MA, Condorí S, Leotta GA, Chinen I, Miliwebsky E, Allori C, Aulet O, De Castillo MC. Detección, aislamiento y caracterización de Escherichia coli productor de toxina Shiga a partir de carne molida fresca proveniente de carnicerías de Concepción, provincia de Tucumán. Rev Argent Microbiol. 2010;42:284-287.

64. Kaper JB, Nataro JP, Mobley HL. Pathogenic Escherichia coli. Nat Rev Microbiol. 2004;2:123-140.

65. Kaplan BS, Cleary TG, Obrig TG. Recent advances in understanding the pathogenesis of the hemolytic uremic syndromes. Pediatr Nephrol. 1990;4:276-281.

66. Karch H, Bohm H, Schmidt H, Gunzer F, Aleksic S, Heesemann J. Clonal structure and pathogenicity of Shiga-like toxin-producing, sorbitol-fermenting Escherichia coli O157:H-. J Clin Microbiol. 1993;31:1200-1205.

67. Karch H, Bielaszewska M. Sorbitol-fermenting Shiga toxin-producing Escherichia coli O157:H(-) strains: epidemiology, phenotypic and molecular characteristics, and microbiological diagnosis. J Clin Microbiol. 2001;39:2043-2049.

68. Karmali MA, Steele BT, Petric M, Lim C. Sporadic cases of haemolytic-uraemic syndrome associated with fecal cytotoxin and cytotoxin-producing Escherichia coli in stools. Lancet. 1983;1:619-620.

69. Karmali MA, Petric M, Lim C, Cheung R, Arbus GS. Sensitive method for detecting low numbers of verotoxin-producing Escherichia coli in mixed cultures by use of colony sweeps and polymyxin extraction of verotoxin. J Clin Microbiol. 1985;22:614-619.

70. Klapproth JM, Scaletsky IC, McNamara BP, Lai LC, Malstrom C, James SP, Donnenberg MS. A large toxin from pathogenic Escherichia coli strains that inhibits lymphocyte activation. Infect Immun. 2000;68:2148-2155.

71. Knowalchuk J, Speir JI, Stavric S. Vero response to a cytotoxin of Escherichia coli. Infect Immun. 1977;18:775-779. 
72. Knutton S, Lloy DR, McNeish AS. Adhesion of enteropathogenic Escherichia coli to human intestinal enterocytes and cultured human intestinal mucosa. Infect Immun. 1987;55:69-77.

73. Kokai-Kun JF, Melton-Celsa AR, O'Brien AD. Elastase in intestinal mucus enhances the cytotoxicity of Shiga toxin type 2d. J Biol Chem. 2000;275:3713-3721.

74. Large TM, Walk ST, Whittam TS. Variation in acid resistance among Shiga toxinproducing clones of pathogenic Escherichia coli. Appl Environ Microbiol. 2005;71:2493-2500.

75. Leotta GA, Chinen I, Epszteyn S, Miliwebsky E, Melamed IC, Motter M, Ferrer M, Marey E, Rivas M. Validation of a multiplex PCR for detection of Shiga toxin-producing Escherichia coli. Rev Arg Microbiol. 2005;37:1-10.

76. Leotta GA, Deza N, Origlia J, Toma C, Chinen I, Miliwebsky E, lyoda S, Sosa-Estani S, Rivas M. Detection and characterization of Shiga toxin-producing Escherichia coli in captive non-domestic mammals. Vet Microbiol. 2006;118:151-157.

77. Leung PHM, Peiris JSM, Ng WWS, Robins-Browne RM, Bettelheim KA, Yam WC. A newly discovered verotoxin variant, VT2g, produced by bovine verocytotoxigenic Escherichia coli. Appl Environ Microbiol. 2003;69:7549-7553.

78. Lloyd SJ, Ritchie JM, Rojas López M, Blumentritt CA, Popov VL, Greenwich JL, Waldor MK, Torres AG. A double long polar fimbriae mutant of Escherichia coli O157:H7 expresses curli and exhibits reduced in vivo colonization. Infect and Immun. 2012. doi: 10.1128/ IAI.05945-11. [Epub ahead of print].

79. López EL, Díaz M, Grinstein S, Devoto S, Mendilaharzu F, Murray BE, Ashkenazi S, Rubeglio E, Woloj M, Vasquez M, Turco M, Pickering LK, Cleary TG. Hemolytic Uremic Syndrome and diarrhea in Argentine children; the role of Shiga-like toxins. J Infect Dis. 1989;160:469-475.

80. López F, Isequilla PE, Kaplan D. Enfermedades de transmisión hídrico en el Río de La Plata, Diagnóstico de situación Enero-Junio 1998. Gobierno de la Ciudad de Buenos Aires. 1998. 
81. Luck SN, Bennett-Wood V, Poon R, Robins-Browne RM, Hartland EL. Invasion of epithelial cells by locus of enterocyte effacement-negative enterohemorrhagic Escherichia coli. Infect Immun. 2005;73:3063-3071.

82. Luck SN, Badea L, Bennett-Wood V, Robins-Browne R, Hartland EL. Contribution of FliC to epithelial cell invasion by enterohemorrhagic Escherichia coli O113:H21. Infect Immun. 2006;74:6999-7004.

83. Lymberopoulos $\mathrm{MH}$, Houle $\mathrm{S}$, Daigle $\mathrm{F}$, Léveillé $\mathrm{S}$, Brée $\mathrm{A}$, Moulin-Schouleur $\mathrm{M}$, Johnson JR, Dozois CM. Characterization of Stg fimbriae from an avian pathogenic Escherichia coli 078:K80 strain and assessment of their contribution to colonization of the chicken respiratory tract. J Bacteriol. 2006;188:6449-6459.

84. Mahajan A, Currie CG, Mackie S, Tree J, McAteer S, McKendrick I, McNeilly TN, Roe A, La Ragione RM, Woodward MJ, Gally DL, Smith DG. An investigation of the expression and adhesin function of $\mathrm{H} 7$ flagella in the interaction of Escherichia coli $\mathrm{O} 157: \mathrm{H} 7$ with bovine intestinal epithelium. Cell Microbiol. 2009;11:121-137.

85. Masana MO, Leotta GA, Del Castillo LL, D’Astek BA, Palladino PM, Galli L, Vilacoba E, Carbonari C, Rodríguez HR, Rivas M. Prevalence, characterization, and genotypic analysis of Escherichia coli O157:H7/NM from selected beef exporting abattoirs of Argentina. J Food Protect. 2010;73:649-656.

86. Masana MO, D'Astek BA, Palladino PM, Galli L, Del Castillo LL, Carbonari C, Leotta GA, Vilacoba E, Irino K, Rivas M. Genotypic Characterization of Non-O157 Shiga ToxinProducing Escherichia coli in Beef Abattoirs of Argentina. J Food Protect. 2011;74:20082017.

87. McClain MS, Blomfield IC, Eisenstein BI. Roles of fimB and fimE in site-specific DNA inversion associated with phase variation of type 1 fimbriae in Escherichia coli. J Bacteriol. 1991;173:5308-5314.

88. Meichtri L, Miliwebsky E, Gioffré A, Chinen I, Baschkier A, Chillemi G, Guth BE, Masana MO, Cataldi A, Rodríguez HR, Rivas M. Shiga toxin-producing Escherichia coli in healthy 
young beef steers from Argentina: prevalence and virulence properties. I J Food Microbiol. 2004;96:189-198.

89. Melton-Celsa AR, Darnell SC, O'Brien AD. Activation of Shiga-like toxins by mouse and human intestinal mucus correlates with virulence of enterohemorrhagic Escherichia coli O91:H21 isolates in orally infected, streptomycin-treated mice. Infect Immun. 1996;64:15691576.

90. Mercado EC. Control de Escherichia coli enterohemorrágico (EHEC) en el ganado bovino. Medicina (B Aires) 2006;66:33-36.

91. Miliwebsky E, Deza N, Chinen I, Martínez Espinosa E, Gómez D, Pedroni E, Caprile L, Bashckier A, Manfredi E, Leotta GA, Rivas M. Prolonged fecal shedding of Shiga toxinproducing Escherichia coli among children attending day-care centers in Argentina. Rev Argent Microbiol. 2007;39:90-92.

92. Newton HJ, Sloan J, Bennett-Wood V, Adams LM, Robins-Browne RM, Hartland EL. Contribution of long polar fimbriae to the virulence of rabbit-specific enteropathogenic Escherichia coli. Infect Immun. 2004;72:1230-1239.

93. Nicholls L, Grant TH, Robins-Browne RM. Identification of a nobel genetic locus that is required for in vitro adhesion of a clinical isolated of enterohaemorrhagic Escherichia coli to epithelial cells. Mol Microbiol. 2000;35:275-288.

94. O’Brien AD, La Veck GD, Thompson MR, Formal SB. Production of Shigella dysenteriae type-1- like cytotoxin by Escherichia coli. J Infect Dis. 1982;146:763-769.

95. O'Brien AD, Newland JW, Miller SF, Holmes RK, Smith HW, Formal SB. Shiga-like toxin-converting phages from Escherichia coli strains that cause hemorrhagic colitis or infantile diarrhea. Science. 1984;226:694-696.

96. O’Brien AD, Holmes RK. Shiga and Shiga-like toxins. Microbiol Rev. 1987;51:206-220.

97. Oliveira MG, Brito JRF, Carvalho RR, Guth BEC, Gomes TAT, Vieira MAM, Kato MAMF, Ramos II, Vaz TMI, Irino K. Water buffaloes (Bubalus bubalis) identified as an important 
reservoir of Shiga toxin-producing Escherichia coli in Brazil. Appl Environ Microbiol. 2007;73:5945-5948.

98. Ørskov F, Ørskov I. Serotyping of Escherichia coli. En: Methods in Microbiology. Bergan T (ed). London: Academic Press; 1984. p. 43-112.

99. Ørskov F, Ørskov I, Villar JA. Cattle as reservoir of verotoxin-producing Escherichia coli O157:H7. Lancet 1987;2:276.

100. Ostroff SM, Tarr PI, Neill MA, Lewis JH, Hargrett-Bean N, Kobayashi JM. Toxin genotypes and plasmid profiles as determinants of systemic sequelae in Escherichia coli O157:H7 infections. J Infect Dis. 1989;160:994-998.

101. Parma AE, Sanz ME, Blanco JE, Blanco J, Blanco M, Padola NL, Etcheverría Al. Virulence genotypes and serotypes of verotoxigenic Escherichia coli isolated from cattle and foods in Argentina. Eur J Epidemiol. 2000;16:757-62.

102. Paton AW, Woodrow MC, Doyle RM, Lanser JA, Paton JC. Molecular characterization of Shiga-toxigenic Escherichia coli O113:H21 strain lacking eae responsible for a cluster of cases of hemolytic-uremic syndrome. J Clin Microbiol. 1999;37:3357-3361.

103. Paton AW, Srimanote P, Woodrow MC, Paton JC. Characterization of Saa, a novel autoagglutinating adhesin produced by locus of enterocyte effacement-negative Shigatoxigenic Escherichia coli strains that are virulent for humans. Infect Immun. 2001;69:69997009 .

104. Paton AW, Srimanote P, Talbor UM, Wang H, Paton JC. A new family of potent AB5 cytotoxins produced by Shiga toxigenic Escherichia coli. J Exp Med. 2004;200:35-46.

105. Paton JC, Paton AW. Shiga toxin 'goes retro' in human primary kidney cells. Kidney Int. 2006;70:2049-2051.

106. Pièrard D, Muyldermans G, Moriau L, Stevens D, Lauwers S. Identification of new verocytotoxin type 2 variant B-subunit genes in human and animal Escherichia coli isolates. $J$ Clin Microbiol. 1998;36:3317-3322. 
107. Ray PE, Liu XH. Pathogenesis of Shiga toxin-induced hemolytic uremic syndrome. Pediatr Nephrol. 2001;16:823-839.

108. Riley LW, Remis RS, Helgerson SD, McGee HB, Wells JG, Davis BR, Hebert RJ, Olcott ES, Johnson LM, Hargrett NT, Blake PA, Cohen ML. Hemorrhagic colitis associated with a rare Escherichia coli O157:H7 serotype. N Engl J Med. 1983;308:681-685.

109. Ritchie, J. M., C. M. Thorpe, A. B. Rogers, and M. K. Waldor. Critical roles for stx2, eae, and tir in enterohemorrhagic Escherichia coli-induced diarrhea and intestinal inflammation in infant rabbits. Infect Immun. 2003;71:7129-7139.

110. Ribot EM, Fair MA, Gautom R, Cameron DN, Hunter SB, Swaminathan B, Barrett TJ. Standardization of pulsed-field gel electrophoresis protocols for the subtyping of Escherichia coli O157:H7, Salmonella, and Shigella for PulseNet. Foodborne Pathog Dis. 2006;3:59-67.

111. Rivas M, Chinen I, Miliwebsky E, Galli L, Repetto HA, Masana M. Capítulo 8: Epidemiology of Argentinean STEC. En: Bacterial Population Genetics: A Tribute to Thomas S. Whittam. Walk S, Feng P (eds.). ASM Press. Abril 2011, p. 109-132.

112. Rogers TJ, Paton JC, Wang H, Talbot UM, Paton AW. Reduced virulence of an fliC mutant of Shiga-toxigenic Escherichia coli O113:H21. Infect Immun. 2006;74:1962-1966.

113. Römling U, Bian Z, Hammar M, Sierralta WD, Normark S. Curli fibers are highly conserved between Salmonella typhimurium and Escherichia coli with respect to operon structure and regulation. J Bacteriol. 1998;180:722-731.

114. Rojas-López M, Arenas-Hernández MM, Medrano-López A, Martínez de la Peña CF, Puente JL, Martínez-Laguna Y, Torres AG. Regulatory control of the Escherichia coli O157:H7 Ipf1 operon by H-NS and Ler. J Bacteriol. 2011;193:1622-1632.

115. Sambrook J, Fritsch EF, Maniatis T. Molecular Cloning: A Laboratory Manual, Ed 2. Cold Spring Harbor, NY: Cold Spring Harbor Laboratory Press; 1989. pp. A.1-A.2. 
116. Savarino SJ, Fasano A, Robertson DC, Levine MM. Enteroaggregative Escherichia coli elaborate a heat-stable enterotoxin demonstrable in an in vivo rabbit intestinal model. $\mathrm{J}$ Clin Invest. 19991;87:1450-1455.

117. Schering J, Andreoli SP, Zimmerhackl LB. Treatment and outcome of Shiga toxinassociated hemolytic uremic syndrome (HUS). Pediatr Nephrol. 2008;23:1749:1760.

118. Schmidt $H$, Beutin $L$, Karch $H$. Molecular analysis of the plasmid-encoded hemolysin of Escherichia coli O157:H7 strain EDL933. Infect Immun. 1995;63:1055-1061.

119. Schmidt H, Scheef J, Morabito S, Caprioli A, Wieler LH, Karch H. A new Shiga toxin 2 variant (Stx2f) from Escherichia coli isolated from pigeons. Appl Environ Microbiol. 2000;66:1205-1208.

120. Schmitt CK, McKee ML, O'Brien AD. Two copies of Shiga-like toxin II-related genes common in enterohemorrhagic Escherichia coli strains are responsible for the antigenic heterogeneity of the O157:H- strain E32511. Infect Immun. 1991;59:1065-1073.

121. Spizzirri FD, Rahman RC, Bibiloni N, Ruscasso JD, Amoreo OR. Childhood hemolytic uremic syndrome in Argentina: long-term follow-up and prognostic features. Pediatr Nephrol. 1997;11:156-160.

122. Stevens MP, Roe AJ, Vlisidou I, Van Diemen PM, La Ragione RM, Best A, Woodward MJ, Gally DL, Wallis TS. Mutation of toxB and a truncated version of the efa- 1 gene in Escherichia coli 0157:H7 influences the expression and secretion of locus of enterocyte effacement-encoded proteins but not intestinal colonization in calves or sheep. Infect Immun. 2004;72:5402-5411.

123. Talbot UM, Paton JC, Paton AW. Protective Immunization of Mice with an Active-Site Mutant of Subtilase Cytotoxin of Shiga Toxin-Producing Escherichia coli. Infect Immun. 2005;73:4432-4436.

124. Tamm A, Tarkkanen AM, Korhonen TK, Kuusela $P$, Toivanen $P$, Skurnik $M$. Hydrophobic domains affect the collagen-binding specificity and surface polymerization as 
well as the virulence potential of the YadA protein of Yersinia enterocolitica. Mol Microbiol. 1993;10:995-1011.

125. Tarr PI, Bilge SS, Vary JC, Jelacic S, Habeeb RL, Ward TR, Baylor MR, Besser TE. Iha: a novel Escherichia coli $\mathrm{O} 157: \mathrm{H} 7$ adherence-conferring molecule encoded on a recently acquired chromosomal island of conserved structure. Infect Immun. 2000;68:1400-1407.

126. Tarr P, Gordon C, Chandler W. Shiga-toxin producing Escherichia coli and haemolytic uraemic syndrome. Lancet. 2005;365:1073-1086.

127. Tatarczak M, Wieczorek K, Possē B, Osek J. Identification of putative adhesin genes in shigatoxigenic Escherichia coli isolated from different sources. Vet Microbiol. 2005;110:7785.

128. Tatsuno I, Horie M, Abe H, Miki T, Makino K, Shinagawa H, Taguchi H, Kamiya S, Hayashi T, Sasakawa C. toxB gene on p0157 of enterohemorrhagic Escherichia coli O157:H7 is required for full epithelial cell adherence phenotype. Infect Immun. 2001;69:6660-6669.

129. Tatsuno I, Mundy R, Frankel G, Chong Y, Phillips AD, Torres AG, Kaper JB. The Ipf gene cluster for long polar fimbriae is not involved in adherence of enteropathogenic Escherichia coli or virulence of Citrobacter rodentium. Infect Immun. 2006;74:265-272.

130. Tesh VL, Burris JA, Owens JW, Gordon VM, Wadolkowski EA, O'Brien AD, Samuel JE. Comparison of the relative toxicities of Shiga-like toxins type I and type II for mice. Infect Immun. 1993;61:3392-3402.

131. Toma C, Espinosa EM, Song T, Miliwebsky E, Chinen I, lyoda S, Iwanaga M, Rivas M. Distribution of Putative Adehesins in Different Seropathotypes of Shiga Toxin-Producing Escherichia coli. J Clin Microbiol. 2004;42:4937-4946.

132. Toma C, Higa N, lyoda S, Rivas M, Iwanaga M. The long polar fimbriae genes identified in Shiga toxin-producing Escherichia coli are present in other diarrheagenic E. coli and in the standard E. coli collection of reference (ECOR) strains. Res Microbiol. 2006;157:153-161. 
133. Toma C, Nakasone N, Miliwebsky E, Higa N, Rivas M, Suzuki T. Differential adherence of Shiga toxin-producing Escherichia coli harboring saa to epithelial cells. Int $\mathrm{J}$ Med Microbiol. 2008;298:571-578.

134. Torres AG, Giron JA, Perna NT, Burland V, Blattner FR. Avelino-Flores F, Kaper JB. Identification and characterization of IpfABCC'DE, a fimbrial opreron of enterohemorrhagic Escherichia coli O157:H7. Infect Immun. 2002;70:5416-5427.

135. Torres AG, Kanack KJ, Tutt CB, Popov V, Kaper JB. Characterization of second long polar (LP) fimbriae of Escherichia coli O157:H7 and distribution of LP in other pathogenic $E$. coli strains. FEMS Microbiol Lett. 2004; 238:333-344.

136. Torres AG, Milflores-Flores L, Garcia-Gallegos JG, Patel SD, Best A, La Ragione RM, Martinez-Laguna $Y$, Woodward MJ. Environmental regulation and colonization attributes of the long polar fimbriae of Escherichia coli O157:H7. Int J Med Microbiol. 2007a;297:177-185.

137. Torres AG, López-Sánchez GN, Milflores-Flores L, Patel SD, Rojas-López M, Martínez de la Peña CF, Arenas-Hernández MM, Martínez-Laguna Y. Ler and H-NS, regulators controlling expression of the long polar fimbriae of Escherichia coli O157:H7. J Bacteriol. 2007b;189:5916-5928.

138. Torres AG, Blanco M, Valenzuela P, Slater TM, Patel SD, Dahbi G, López C, Fernández Barriga X, Blanco JE, Gomes TAT, Vidal R, Blanco J. The long polar fimbriae genes of pathogenic Escherichia coli strains as reliable markers to identify virulent isolates. $J$ Clin Microbiol. 2009;47:2442-2451.

139. Tyler SD, Johnson WM, Lior H, Wang G, Rozee KR. Identification of Verotoxin type 2 variant B subunit genes in Escherichia coli by the polymerase chain reaction and restriction fragment length polymorphism analysis. J Clin Microbiol. 1991;29:1339-1343.

140. Veilleux S, Dubreuil JD. Presence of Escherichia coli carrying the EAST1 toxin gene in farm animals. Vet Res. 2006;37:3-13. 
141. Watanabe H, Wada A, Inagaki $\mathrm{Y}$, Itoh $\mathrm{K}$, Tamura K. Outbreaks of enterohaemorrhagic Escherichia coli O157:H7 infection by two different genotype strains in Japan. Lancet. 1996;348:831-832.

142. Weinstein DL, Jackson MP, Samuel JE, Holmes RK, O'Brien AD. Cloning and sequencing of a Shiga-like toxin type II variant from Escherichia coli strain responsible for edema disease of swine. J Bacteriol. 1988;170:4223-4230.

143. Wells JG, Shipman LD, Greene KD, Sowers EG, Green JH, Cameron DN, Downes FP, Martin ML, Griffin PM, Ostroff SM, Potter ME, Tauxe RV, Wachsmuth IK. Isolation of Escherichia coli serotype 0157:H7 and other Shiga-like-toxin-producing E. coli from dairy cattle. J Clin Microbiol. 1991;29:985-989.

144. Williams ND, Torres AG, Lloyd SJ. Evolution and epidemiology of diarrheagenic Escherichia coli. En: Pathogenic Escherichia coli in Latin America. Torres AG (Ed). Bentham Books. Abril 2011. pp. 8-24.

145. Wong CS, Jelacic S, Habeeb RL, Watkins SL, Tarr PI. The risk of the hemolytic-uremic syndrome after antibiotic treatment of Escherichia coli O157: H7 infections. N Engl J Med. 2000;342:1930-1936.

146. Yamamoto T, Echeverria P. Detection of the enteroaggregative Escherichia coli heatstable enterotoxin 1 gene sequences in enterotoxigenic $E$. coli strains pathogenic for humans. Infect Immun. 1996;64:1441-1445.

147. Zhang W, Bielaszewska M, Thorsten K, Karch H. Identification, characterization, and distribution of a Shiga toxin 1 gene variant (stx1c) in Escherichia coli strains isolated from humans. J Clin Microbiol. 2002;40:1441-1446.

148. Zweifel C, Schumacher S, Beutin L, Blanco J, Stephan R. Virulence profile of Shiga toxin 2e-producing Escherichia coli isolated from healthy pig at slaughter. Vet Microbiol. 2006;117:328-332. 